medRxiv preprint doi: https://doi.org/10.1101/2020.05.14.20101311; this version posted May 20, 2020. The copyright holder for this preprint (which was not certified by peer review) is the author/funder, who has granted medRxiv a license to display the preprint in perpetuity. It is made available under a CC-BY-ND 4.0 International license .

Lawrence Livermore National Laboratory

\section{Reducing Exposures to Airborne Particles Through Improved Filtration: A High-Level Modeling Analysis}

\author{
Michael B Dillon \\ Richard G Sextro
}

April 2020

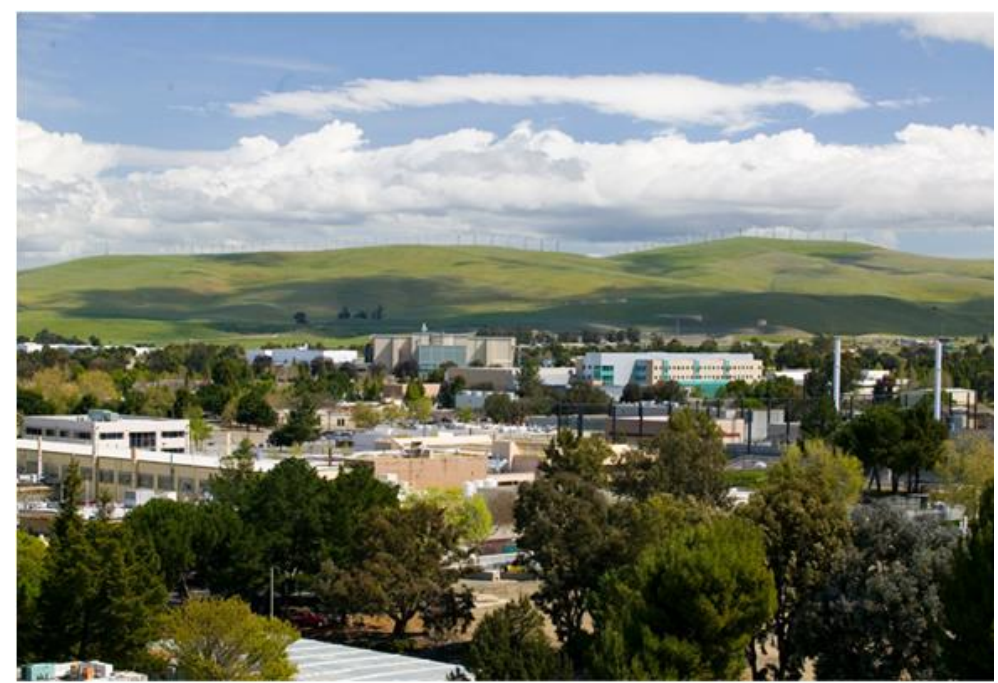


medRxiv preprint doi: https://doi.org/10.1101/2020.05.14.20101311; this version posted May 20, 2020. The copyright holder for this preprint (which was not certified by peer review) is the author/funder, who has granted medRxiv a license to display the preprint in perpetuity. It is made available under a CC-BY-ND 4.0 International license.

\section{Auspices and Disclaimer}

This work was performed under the auspices of the U.S. Department of Energy by Lawrence Livermore National Laboratory under Contract DE-AC52-07NA27344.

This document was prepared as an account of work sponsored by an agency of the United States government. Neither the United States government nor Lawrence Livermore National Security, LLC, nor any of their employees makes any warranty, expressed or implied, or assumes any legal liability or responsibility for the accuracy, completeness, or usefulness of any information, apparatus, product, or process disclosed, or represents that its use would not infringe privately owned rights. Reference herein to any specific commercial product, process, or service by trade name, trademark, manufacturer, or otherwise does not necessarily constitute or imply its endorsement, recommendation, or favoring by the United States government or Lawrence Livermore National Security, LLC. The views and opinions of authors expressed herein do not necessarily state or reflect those of the United States government or Lawrence Livermore National Security, LLC, and shall not be used for advertising or product endorsement purposes. 
medRxiv preprint doi: https://doi.org/10.1101/2020.05.14.20101311; this version posted May 20, 2020. The copyright holder for this preprint

(which was not certified by peer review) is the author/funder, who has granted medRxiv a license to display the preprint in perpetuity.

It is made available under a CC-BY-ND 4.0 International license .

M Dillon and

R Sextro
Reducing Exposures to Airborne

Particles Through Improved Filtration

\section{Reducing Exposures to Airborne Particles} Through Improved Filtration: A High-Level Modeling Analysis

Authors

Michael B Dillon dillon7@|lnl.gov (Lawrence Livermore National Laboratory)

Richard G Sextro rgsextro@|bl.gov (Lawrence Berkeley National Laboratory)

9 1. Abstract

10 Indoor airborne particulates are well-known health hazards and filtration is one common

11 method of reducing exposures. Based on our previously developed Regional Shelter Analysis methodology and parameters that characterize the existing US building stock, we perform a high-level assessment of the potential benefits of upgrading existing filters in furnace and in heating, ventilation, and air conditioning systems using off-the-shelf filters. We use three metrics to assess the improvement: Building Transmission Factor (a measure of protection against outdoor airborne particles), Indoor Normalized Time and Space Integrated Air Concentration (a measure of indoor exposure to indoor-origin airborne particles), and Building Exit Fraction (fraction of indoor airborne particles that are released to the outdoor atmosphere). We also discuss the potential reduction in regional exposures due to particles exiting the building and exposing downwind building occupants.

Our modeling indicates that while buildings provide their occupants passive protection against airborne particulate hazards, including but not limited to $\mathrm{PM}_{2.5}, \mathrm{PM}_{10}$, and wildfire smoke; improving particle filtration efficiency may further improve this protection. The degree of improvement varies with particle size and building type. Of the building types studied, apartments are predicted to benefit most, with greater than a factor of 2 improvement ( $\geq 50 \%$ reduction in exposures) for $1 \mu \mathrm{m}$ particle exposures when using MERV 7 to 12 rated filters. Non-residential buildings were notably less responsive to improved filtration but had the highest Building Exit Fractions with $30 \%$ to $40 \%$ of indoor airborne particles released to the outdoor atmosphere (apartment buildings only released $6 \%$ to $9 \%$ ). Improvements predicted for single family homes were intermediate between apartments and non-residential buildings. Improvements in the Regional Exposure metric are larger, ranging from a factor of $2.5 x$ to $10 x$ for residences (when using MERV 7 to 12 rated filters) and up to $25 x$ for large apartments with MERV 14 or 15 rated filters. The results of our modeling analysis are broadly consistent with the limited experimental data and modeling results available in the literature. 
medRxiv preprint doi: https://doi.org/10.1101/2020.05.14.20101311; this version posted May 20, 2020. The copyright holder for this preprint

(which was not certified by peer review) is the author/funder, who has granted medRxiv a license to display the preprint in perpetuity.

It is made available under a CC-BY-ND 4.0 International license .

M Dillon and

R Sextro
Reducing Exposures to Airborne Particles Through Improved Filtration

\section{Table of Contents}

1. Abstract.

2. Introduction 3

3. Building Models and Key Metrics ................................................................... 4

3.1. Reducing Indoor Exposures to Outdoor Airborne Particles (Building Transmission Factor) ....7

3.2. Reducing Indoor Exposures to Indoor Airborne Particles (Indoor Normalized TSIAC) . .9

3.3. Fraction of Indoor Airborne Particles Released to the Outdoors (Exit Fraction)

3.4. Regional Exposures

4. Building Parameter Values

4.1. Building Model Assignment.

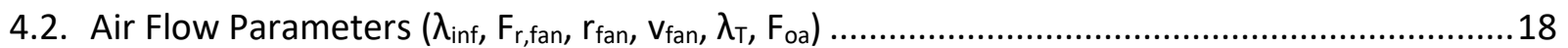

4.3. Particle Size Specific Parameters ( $\left.\lambda_{\text {dep }}, L_{\text {inf, }} F_{\text {filter }}\right)$

5. Results.

5.1. Reducing Indoor Exposures to Outdoor Airborne Particles (Building Transmission Factor) ..28

5.2. Reducing Indoor Exposures to Indoor Airborne Particles (Indoor Normalized TSIAC)

5.3. Fraction of Indoor Airborne Particles Released to the Outdoors (Building Exit Fraction) ......34

6. Discussion and Conclusion

9. References.

61 Supplemental Material C: Additional Building Metric Figures 
medRxiv preprint doi: https://doi.org/10.1101/2020.05.14.20101311; this version posted May 20, 2020. The copyright holder for this preprint (which was not certified by peer review) is the author/funder, who has granted medRxiv a license to display the preprint in perpetuity. It is made available under a CC-BY-ND 4.0 International license .

M Dillon and

R Sextro
Reducing Exposures to Airborne Particles Through Improved Filtration

\section{Introduction}

66 Indoor exposure to airborne particles can arise from many outdoor and indoor sources and

67 sufficient exposures are known to result in acute and chronic lung disease as well as heart

68 disease [1]-[5]. Buildings can passively provide - in some cases significant - protection to their

69 occupants from a broad range of particle inhalation hazards - including but not limited to $\mathrm{PM}_{2.5}$,

$70 \mathrm{PM}_{10}$, and wildfire smoke - as discussed in detail in [6], [7]. Using the Regional Shelter Analysis

71 (RSA) method described in [6], we previously estimated the passive protection provided by the

72 existing US building stock for airborne particulate hazards [7]. The present work - utilizing the

73 same RSA approach - focuses on the degree to which straightforward changes in building

74 operation could yield an additional measure of protection. Specifically, this report considers the

75 building protection benefits of improving current particle filtration efficiency by (a) using off-

76 the-shelf furnace and heating, ventilation, and air conditioning (HVAC) system filters and (b)

77 increased furnace fan operation for residential buildings.

78 Our modeling uses the Building Transmission Factor metric (BTF) which is the ratio of indoor to outdoor exposures, where exposures are time-integrated airborne particle concentrations. The

80 BTF, sometimes called the Building Exposure Ratio, is the inverse of the Building Protection

81 Factor metric used in our previous RSA work [6], [7]. In addition to the BTF, two related, but

82 distinct, building metrics are also of interest and are analyzed here: (a) the Indoor Normalized

83 Time and Space Integrated Air Concentration (TSIAC) which is the degree to which indoor

84 individuals are exposed to indoor airborne particles (the indoor time and space integrated air 85 concentration normalized to the release of a unit amount of airborne material, such as a single

86 particle or a $\mu \mathrm{g}$ of material) and (b) the Building Exit Faction (BEF) which is the fraction of indoor

87 airborne particulates that exit the building and enter the outdoor atmosphere. The potential

88 improvement in (i.e., reduction in) regional exposures that arises due to the reduction in both

89 the number of particles exiting the building and entering downwind buildings is also discussed. 
medRxiv preprint doi: https://doi.org/10.1101/2020.05.14.20101311; this version posted May 20, 2020. The copyright holder for this preprint (which was not certified by peer review) is the author/funder, who has granted medRxiv a license to display the preprint in perpetuity. It is made available under a CC-BY-ND 4.0 International license .

M Dillon and

R Sextro
Reducing Exposures to Airborne Particles Through Improved Filtration

\section{Building Models and Key Metrics}

92 Outdoor airborne particles can enter a building through mechanical ventilation (e.g., HVAC

93 systems), natural ventilation (e.g., open windows), and/or infiltration (e.g., through exterior

94 wall cracks). Once indoors, airborne particles can be removed from the indoor air through (a)

95 air leaving the building by mechanical or natural ventilation and exfiltration; (b) active filtration

96 by recirculation through furnace or HVAC systems (if present); (c) deposition on indoor surfaces

97 (particle resuspension is not accounted for in this study); and (d) other processes, including but

98 not limited to, chemical reactions and portable (stand-alone) indoor air filtration systems

99 (neither of which are considered here). For this study, we have assumed building doors and

100 windows are closed.

101 Modeling indoor contaminant concentrations requires choosing among a variety of

102 mathematical models with increasing complexity, ranging from simple single compartment

103 models to multizone models to highly detailed computational fluid dynamics models. While

104 increasingly detailed and complex models may reduce modeling conservatism and uncertainty,

105 the number and required fidelity of the input parameters also increases (see [8] for a general

106 discussion). Since our goal is to provide a broad, high level assessment across a range of

107 building categories and, as a practical matter, detailed parameters are not generally available

108 for many buildings of interest; we make two key modeling assumptions (these assumptions are 109 consistent with prior studies [9]-[12]). First, indoor air volumes, such as the breathing space of

110 a building, can be represented as a single compartment, which can be used to describe the time

111 evolution of indoor contaminant concentrations. Second, airborne particle concentrations

112 within that single compartment are spatially uniform.

113 These assumptions are codified in the single box model (Equation 1) which can be used to

114 describe the time evolution of indoor airborne particle concentrations. This study includes the

115 additional, commonly used assumption that the transport and loss terms, i.e., the $\lambda$

116 parameters, are independent of both time and air concentration on the timescales of interest.

$$
\frac{d C_{\text {Indoor }}}{d t}=\lambda_{\text {in }} \times C_{\text {outdoor }}(t)-\left(\lambda_{\text {out }}+\lambda_{\text {internal }}\right) \times C_{\text {Indoor }}(t)
$$


medRxiv preprint doi: https://doi.org/10.1101/2020.05.14.20101311; this version posted May 20, 2020. The copyright holder for this preprint (which was not certified by peer review) is the author/funder, who has granted medRxiv a license to display the preprint in perpetuity. It is made available under a CC-BY-ND 4.0 International license .

M Dillon and

R Sextro
Reducing Exposures to Airborne Particles Through Improved Filtration

120 where

121

$122 \lambda_{\text {in }}=$ the rate at which outdoor airborne particles enters the building - typically via infiltration or

123 ventilation. Includes losses that occur during transport from outdoor to indoor $\left(\mathrm{h}^{-1}\right)$

$124 \lambda_{\text {internal }}=$ the rate at which indoor airborne particles are lost within the building - typically by

125 deposition to surfaces or by filtration $\left(\mathrm{h}^{-1}\right)$

$126 \lambda_{\text {out }}=$ the rate at which indoor airborne particles exit the building - typically via exfiltration or

$127 \quad$ ventilation $\left(\mathrm{h}^{-1}\right)$

$128 C_{\text {Indoor }}(t)=$ the indoor particle air concentration at time $\mathrm{t}\left(\mathrm{g} \mathrm{m}^{-3}\right)$

$129 C_{\text {Outdoor }}(t)=$ the outdoor particle air concentration at time $\mathrm{t}\left(\mathrm{g} \mathrm{m}^{-3}\right)$

$130 t=$ time $(\mathrm{h})$

131 
medRxiv preprint doi: https://doi.org/10.1101/2020.05.14.20101311; this version posted May 20, 2020. The copyright holder for this preprint (which was not certified by peer review) is the author/funder, who has granted medRxiv a license to display the preprint in perpetuity. It is made available under a CC-BY-ND 4.0 International license.

M Dillon and R Sextro Reducing Exposures to Airborne Particles Through Improved Filtration

132 We adapt Equation 1 to develop two sets of generalized equations for each of the three 133 building metrics (Building Transmission Factor, Indoor Normalized TSIAC, and Building Exit 134 Fraction). Each equation set is defined on the basis of one of two common combinations of (a) 135 the two building airflow mechanisms described above (filtered recirculation; HVAC systems) 136 and (b) the relevant indoor loss mechanisms. In addition to any filtration that might be present, 137 and already incorporated into the airflow terms, we consider two additional indoor loss

138 mechanisms: (a) deposition of airborne particles to indoor surfaces, $\lambda_{\text {dep }}$, and (b) a generic first-

139 order airborne loss mechanism that can be used to account for other loss mechanisms not 140 explicitly considered in this analysis, $\lambda_{\text {decay }}$. Several parameters are particle-size-dependent. For 141 readability, these dependencies are not shown in the equations themselves, but are denoted by 142 (particle size) in the list of variable definitions.

143 The first set of airflow equations (denoted by $\mathbf{R}$ ) corresponds to buildings with filtered 144 recirculation, which in the US are typically residences. Outdoor airborne material enters the 145 building only through the infiltration pathway. The forced air furnace recirculation air filter, if 146 present and active (fan on), removes a fraction of indoor airborne particles.

147 The second set of airflow equations (denoted by $\mathbf{H}$ ) corresponds to buildings with an active 148 HVAC system, which in the US are typically non-residential buildings. Outdoor airborne material 149 enters the building through either infiltration or the HVAC system outdoor air intake. The HVAC 150 system air filter removes airborne particles from both the entering and recirculating air. This 151 equation implicitly assumes that the HVAC system fan duty cycle is $100 \%$ (the system is always 152 moving building air, although not necessarily heating or cooling it). 
medRxiv preprint doi: https://doi.org/10.1101/2020.05.14.20101311; this version posted May 20, 2020. The copyright holder for this preprint (which was not certified by peer review) is the author/funder, who has granted medRxiv a license to display the preprint in perpetuity. It is made available under a CC-BY-ND 4.0 International license .

M Dillon and

R Sextro

Reducing Exposures to Airborne Particles Through Improved Filtration

\subsection{Reducing Indoor Exposures to Outdoor Airborne Particles (Building Transmission}

The building transmission factor equations were previously derived in [6], [7], where the Building Protection Factor metric was used. Equation 2 provides the general form. This term is the ratio of the total indoor exposure to total outdoor exposure. For this application, exposure is defined as the time-integrated airborne particle concentration, hence the Building Transmission Factor is not simply the ratio of indoor to outdoor concentrations. [6], [7] provide more details, discussion, and alternative equations for other exposure metrics.

$$
\text { [Building Transmission Factor] }=\frac{1}{\text { [Building Protection Factor }]}
$$

$$
=\frac{\int C_{\text {Indoor }}(t) d t}{\int C_{\text {outdoor }}(t) d t}=\frac{\lambda_{\text {in }}}{\left(\lambda_{\text {out }}+\lambda_{\text {internal }}\right)}
$$

$$
[\text { Building Transmission Factor }]=\frac{\left(\lambda_{\text {inf }} \times L_{\text {inf }}\right)}{\lambda_{\text {inf }}+\left(F_{\text {filter }} \times F_{r, f a n} \times r_{\text {fan }}+\lambda_{\text {dep }}+\lambda_{\text {decay }}\right)}
$$

170 For buildings with an active HVAC system, Equation $\mathbf{3 H}$ specifies the Building Transmission 171 Factor.

$$
[\text { Building Transmission Factor }]=\frac{\left(\lambda_{\text {inf }} \times L_{\text {inf }}+v_{\text {fan }} \times F_{o a} \times\left(1-F_{\text {filter }}\right)\right)}{\lambda_{T}+\left(F_{\text {filter }} \times v_{\text {fan }} \times\left(1-F_{o a}\right)+\lambda_{\text {dep }}+\lambda_{\text {decay }}\right)}
$$


medRxiv preprint doi: https://doi.org/10.1101/2020.05.14.20101311; this version posted May 20, 2020. The copyright holder for this preprint

(which was not certified by peer review) is the author/funder, who has granted medRxiv a license to display the preprint in perpetuity.

It is made available under a CC-BY-ND 4.0 International license .

M Dillon and

R Sextro
Reducing Exposures to Airborne Particles Through Improved Filtration

175 where

176

$177 \lambda_{\text {dep }}($ particle size $)=$ the particle-size-dependent indoor deposition loss rate $\left(\mathrm{h}^{-1}\right)$

$178 \lambda_{\text {decay }}=$ the "generic" first-order airborne decay (loss) rate. This term is used to estimate the impact of

179 loss mechanisms that are NOT otherwise specified. $\left(\mathrm{h}^{-1}\right)$

$180 \lambda_{\text {inf }}=$ the air infiltration rate at which air enters a building $\left(\mathrm{h}^{-1}\right)$

$181 \lambda_{T}=$ the total building ventilation rate [= sum of the infiltration and mechanical ventilation rates] $\left(\mathrm{h}^{-1}\right)$.

182

$183 L_{\text {inf }}($ particle size $)=$ the particle-size-dependent efficiency by which particles can penetrate the

184 building shell (dimensionless)

$185 F_{\text {filter }}($ particle size $)=$ the particle-size-dependent filtration efficiency (dimensionless)

$186 F_{o a}=$ the fraction of outdoor air passing through the HVAC supply fan (dimensionless)

$187 \quad F_{r, f a n}=$ the fraction of time the forced air furnace recirculation fan is on, i.e., the fan's duty cycle

188 (dimensionless)

$189 r_{f a n}=$ the rate at which a building volume of air recirculates through the furnace systems when the fan

190 is on $\left(\mathrm{h}^{-1}\right)$

$191 v_{f a n}=$ the rate at which a ventilation or HVAC supply fan delivers a building volume of air when the fan

192 is on and combines the outside and recirculation air rates $\left(\mathrm{h}^{-1}\right)$

193

194 [Building Protection Factor] = ratio of the outdoor to indoor exposure. Similar to sunscreen and

195 personal protective respirator rating systems, higher protection factor values indicate lower

196 exposures and thus increased protection. (protection factor)

197 [Building Transmission Factor] = ratio of the indoor to outdoor exposure. ( (protection factor $)^{-1}$ ) 
medRxiv preprint doi: https://doi.org/10.1101/2020.05.14.20101311; this version posted May 20, 2020. The copyright holder for this preprint (which was not certified by peer review) is the author/funder, who has granted medRxiv a license to display the preprint in perpetuity. It is made available under a CC-BY-ND 4.0 International license .

M Dillon and

R Sextro

Reducing Exposures to Airborne Particles Through Improved Filtration

\subsection{Reducing Indoor Exposures to Indoor Airborne Particles (Indoor Normalized} TSIAC)

The following equations define the indoor normalized time and space integrated airborne particle concentration (Indoor Normalized TSIAC). While this metric can be applied more generally, it is used here to evaluate the exposure to particles released indoors. The equations are developed with the additional assumptions that outdoor airborne particle concentrations are zero and the indoor emission of a single particle occurs at single time $(t=0)$. With these assumptions, Equation 1 simplifies to Equation 4. When a unit amount of material is released indoors at $t=0$, Equation 4 reduces to Equation 5 .

$$
C_{\text {Indoor }}(t)=C_{\text {Indoor }}(t=0) \times e^{-\left(\lambda_{\text {out }}+\lambda_{\text {internal }}\right) t}
$$

$$
[\text { Indoor Normalized TSIAC }]=[\text { Building Floor Area }] \times \int_{0}^{\infty} C_{\text {Indoor }}(t) d t
$$$$
=[\text { Building Floor Area }] \times\left(\frac{1}{[\text { Building Volume }]}\right) \times\left(\lambda_{\text {out }}+\lambda_{\text {internal }}\right)^{-1}
$$

For buildings with filtered recirculation, Equation 6R specifies the Indoor Normalized TSIAC.

$$
=\frac{1}{[\text { Room Height }] \times\left(\lambda_{\text {out }}+\lambda_{\text {internal }}\right)}
$$

$$
=\frac{1}{[\text { Room Height }] \times\left(\lambda_{\text {inf }}+\left(F_{\text {filter }} \times F_{r, f a n} \times r_{\text {fan }}+\lambda_{\text {dep }}+\lambda_{\text {decay }}\right)\right)}
$$


medRxiv preprint doi: https://doi.org/10.1101/2020.05.14.20101311; this version posted May 20, 2020. The copyright holder for this preprint (which was not certified by peer review) is the author/funder, who has granted medRxiv a license to display the preprint in perpetuity.

It is made available under a CC-BY-ND 4.0 International license .

M Dillon and

Reducing Exposures to Airborne

R Sextro

Particles Through Improved Filtration

221 For buildings with an active HVAC system, Equation $6 \mathbf{H}$ specifies the Indoor Normalized TSIAC.

223 [Indoor Normalized TSIAC]

224

$$
=\frac{1}{[\text { Room Height }] \times\left(\lambda_{T}+\left(F_{\text {filter }} \times v_{\text {fan }} \times\left(1-F_{\text {oa }}\right)+\lambda_{\text {dep }}+\lambda_{\text {decay }}\right)\right)}
$$

225

226 where

227

228 [Building Floor Area] $=$ floor area of the building $\left(\mathrm{m}^{2}\right)$

229 [Indoor Normalized TSIAC] $=$ indoor time and space integrated air concentration assuming a unit

230 amount of material is released $\left(\mathrm{s} \mathrm{m}^{-1}\right)$

$231 \quad[$ Room Height $]=$ height of building occupied space $(\mathrm{m})$

232 
medRxiv preprint doi: https://doi.org/10.1101/2020.05.14.20101311; this version posted May 20, 2020. The copyright holder for this preprint (which was not certified by peer review) is the author/funder, who has granted medRxiv a license to display the preprint in perpetuity. It is made available under a CC-BY-ND 4.0 International license .

M Dillon and

R Sextro

\subsection{Fraction of Indoor Airborne Particles Released to the Outdoors (Exit Fraction)}

234 Equation 7 shows the fraction of material released indoors that exits the building and enters

235 the outdoor atmosphere. This equation is based on (a) the appropriate (normalized) indoor

236 concentration (Equation 5), (b) the rate at which indoor air (and airborne material) leaves the

237 building, and (c) particle losses to the building envelope that occur while airborne particles

238 suspended in the indoor air are exiting the building.

$$
[\text { Building Exit Fraction }]=\frac{\int_{0}^{\infty}\left(C_{\text {Indoor }}(t) \times[\text { Building Volume }]\right) \times\left(\lambda_{\text {out }} \times L_{\text {out }}\right) d t}{[\text { Total Particles Released }]}
$$

For buildings with filtered recirculation, outdoor air enters the building only through the infiltration pathway and so $\lambda_{\text {out }}=\lambda_{\text {inf }}$ and Equation 8R specifies the building exit fraction. We assume here that most of the indoor air that exits the building does so via the exfiltration pathway (as opposed to other exit pathways such as bathroom or kitchen exhaust fans, and dryer vents) and therefore $L_{\text {out }}=L_{\text {inf }}$.

$[$ Building Exit Fraction $]=\frac{\lambda_{\text {inf }} \times L_{\text {inf }}}{\lambda_{\text {inf }}+\left(F_{\text {filter }} \times F_{r, f a n} \times r_{\text {fan }}+\lambda_{\text {dep }}+\lambda_{\text {decay }}\right)}$ either infiltration or through mechanical means, e.g., the HVAC system exhaust; Equation $\mathbf{8 H}$ specifies the building exit fraction. Again we note that the entrance and exit airflow paths may differ, but as a practical matter assume (a) that they are the same $\left(\lambda_{\text {out }}=\lambda_{\text {inf }} ; L_{\text {out }}=L_{\text {inf }}\right)$

256 and (b) no particles are lost while the indoor air is exiting through the exhaust system.

258 [Building Exit Fraction $]=\frac{\left(\lambda_{\text {inf }} \times L_{\text {inf }}+v_{\text {fan }} \times F_{o a}\right)}{\lambda_{T}+\left(F_{\text {filter }} \times v_{\text {fan }} \times\left(1-F_{o a}\right)+\lambda_{\text {dep }}+\lambda_{\text {decay }}\right)}$ 
medRxiv preprint doi: https://doi.org/10.1101/2020.05.14.20101311; this version posted May 20, 2020. The copyright holder for this preprint (which was not certified by peer review) is the author/funder, who has granted medRxiv a license to display the preprint in perpetuity. It is made available under a CC-BY-ND 4.0 International license .

M Dillon and

R Sextro
Reducing Exposures to Airborne Particles Through Improved Filtration

259 where

261 [Building Exit Fraction] $=$ fraction of material released within a building that exits the building and 262 enters the outdoor atmosphere. (no units)

$263 L_{\text {out }}($ particle size $)=$ the particle-size-dependent efficiency by which particles in indoor air exit the 264 building through cracks and other penetrations in the building shell (dimensionless) 
medRxiv preprint doi: https://doi.org/10.1101/2020.05.14.20101311; this version posted May 20, 2020. The copyright holder for this preprint (which was not certified by peer review) is the author/funder, who has granted medRxiv a license to display the preprint in perpetuity. It is made available under a CC-BY-ND 4.0 International license .

M Dillon and

R Sextro
Reducing Exposures to Airborne Particles Through Improved Filtration

\subsection{Regional Exposures}

267 Equation 9 describes the fraction of indoor airborne particles that exit a source building, are 268 transported downwind, and enter another building's indoor air space. This metric incorporates 269 both the source Building Exit Fraction (the fraction of indoor airborne particles that exit the 270 source building) and the downwind Building Transmission Factor (the fraction of outdoor 271 airborne particles that enter the second building's air space). The [Outdoor Normalized TSIAC] 272 term in Equation 9, which requires analysis beyond that presented here, assesses the degree to 273 which particles, once emitted from the source building, are transported and diluted in the 274 outdoor atmosphere. Equation 10 defines the Improvement in Downwind Indoor Exposure 275 metric as a ratio to the baseline scenario and so the [Outdoor Normalized TSIAC] terms drops 276 out. This metric can be used to assess the degree to which improved filtration scenarios 277 decrease downwind indoor exposures relative to the baseline scenario.

$=\left(\begin{array}{c}[\text { Total Particles Released Indoors }] \text { (source building }) \\ \times[\text { Building Exit Fraction }](\text { source building }) \\ \times[\text { Outdoor Normalized TSIAC }](\text { source building, downwind building }) \\ \times[\text { Building Footprint }](\text { downwind building }) \\ \times[\text { Building Transmission Factor }](\text { downwind building })\end{array}\right)$ 
medRxiv preprint doi: https://doi.org/10.1101/2020.05.14.20101311; this version posted May 20, 2020. The copyright holder for this preprint

(which was not certified by peer review) is the author/funder, who has granted medRxiv a license to display the preprint in perpetuity.

It is made available under a CC-BY-ND 4.0 International license .

M Dillon and

R Sextro
Reducing Exposures to Airborne Particles Through Improved Filtration

286 where

288 [Building Footprint] (building) $=$ the projected area of the building onto the Earth's surface. $\left(\mathrm{m}^{2}\right)$

289 [Downwind Indoor Exposure](source building, downwind building) = the number of airborne 290 particles in the breathing volume (respiratory second volume) of an individual in the downwind 291 building that were emitted within the source building. (particles $\mathrm{s} \mathrm{m}^{-3}$ )

292 [Improvement in Downwind Indoor Exposure] = ratio of indoor downwind exposure for the 293 baseline scenario to the improved filtration scenario. (no units)

294 [Outoor Normalized TSIAC] (source building, downwind building) = particle air concentration outside the downwind building integrated over the passage of the airborne particulate plume and

298 [Total Particles Released Indoors](source building) = total number of airborne particles released the building footprint assuming a single particle was released to the outdoor atmosphere from the source building. $\left(\mathrm{s} \mathrm{m}^{-3}\right)$ within the source building. (particles) 
medRxiv preprint doi: https://doi.org/10.1101/2020.05.14.20101311; this version posted May 20, 2020. The copyright holder for this preprint (which was not certified by peer review) is the author/funder, who has granted medRxiv a license to display the preprint in perpetuity. It is made available under a CC-BY-ND 4.0 International license .

M Dillon and

R Sextro
Reducing Exposures to Airborne Particles Through Improved Filtration

\section{Building Parameter Values}

302 Our modeling is based on the building use type categories and parameters values described in 303 our earlier report [7] and briefly summarized here. The tables that follow are adapted from that 304 report, where additional discussion and descriptive details may be found. We provide building 305 air flow and particle parameters for most of the US Department of Homeland Security (DHS) 306 HAZUS convention of 33 building use types (termed building occupancy types in the HAZUS documentation), see Table 1; and for individuals outdoors [13]. These parameters are used when calculating the Building Transmission Factor, Indoor Normalized TSIAC, and Building Exit Fraction values from the $\mathbf{R}$ and $\mathbf{H}$ airflow equations.

To assess the benefits from increasing building filter efficiencies, this report compares the effects on indoor airborne particulate concentrations arising from the existing US building stock filter efficiencies - as a baseline scenario - to the concentrations yielded from using higher efficiency filtration scenarios that could be implemented. The only differences in parameters between the baseline scenario and the 3 improved filtration scenarios analyzed are (a) different furnace duty cycles $\left(F_{r}\right.$ fan $)$ in Table 3 below and $(b)$ the choice of filtration categories in Table 9 below. Room height, used in the calculation of the Indoor Normalized TSIAC metric, is assumed

\section{1. $\quad$ Building Model Assignment}

The Table 2 column "Building airflow type" assigns the appropriate airflow equation type ( $\mathbf{R}=$ filtered recirculation; $\mathbf{H}=$ HVAC system) to most US FEMA HAZUS building use type categories specified in Table 1, and also specifies the appropriate airflow parameter values associated with building infiltration, ventilation, and filtration. We note that the prior studies of building performance and/or indoor pollutant behavior (discussed below) were not performed to explicitly conform to HAZUS building use type categories. For some HAZUS building use type categories, e.g., RES1, the mapping between the prior work and the HAZUS category is straightforward. The mapping for other HAZUS categories is less clear and for some categories there are limited published data available. For these cases, we made estimates based on best engineering judgment and adapted the available input data to conform to the HAZUS building types (as discussed below and in [7]). Single box modeling may not adequately represent the indoor airborne particle concentrations for some parking garages (COM10) and so we exclude this building use type from our analysis. 
medRxiv preprint doi: https://doi.org/10.1101/2020.05.14.20101311; this version posted May 20, 2020. The copyright holder for this preprint (which was not certified by peer review) is the author/funder, who has granted medRxiv a license to display the preprint in perpetuity.

It is made available under a CC-BY-ND 4.0 International license .

M Dillon and

R Sextro
Reducing Exposures to Airborne

Particles Through Improved Filtration

334 Table 1. Mapping between HAZUS provided occupancy class and specific building use types. This 335 information is adapted from Table 13.2 presented in [13].

\begin{tabular}{|c|c|c|}
\hline Occupancy class & Building use type & Building use type description \\
\hline \multirow{11}{*}{ Residential } & RES1 & Single family dwelling \\
\hline & RES2 & Manufactured (Mobile) home \\
\hline & RES3A & Multi-family dwelling: duplex \\
\hline & RES3B & Multi-family dwelling: $3-4$ units \\
\hline & RES3C & Multi-family dwelling: 5-9 units \\
\hline & RES3D & Multi-family dwelling: $10-19$ units \\
\hline & RES3E & Multi-family dwelling: 20-49 units \\
\hline & RES3F & Multi-family dwelling: $50+$ units \\
\hline & RES4 & Temporary lodging (e.g., hotel/motel) \\
\hline & RES5 & Institutional dormitory (e.g., military, college, jails) \\
\hline & RES6 & Nursing home \\
\hline \multirow{10}{*}{ Commercial } & COM1 & Retail trade (e.g., stores) \\
\hline & $\mathrm{COM} 2$ & Wholesale trade (e.g., warehouses) \\
\hline & $\mathrm{COM} 3$ & Personal and repair services (e.g., service station/shop) \\
\hline & COM4 & Professional/technical services (e.g., offices) \\
\hline & COM5 & Banks \\
\hline & COM6 & Hospital \\
\hline & COM7 & Medical office/clinic \\
\hline & COM8 & Entertainment and recreation (e.g., restaurants/bars) \\
\hline & COM9 & Theaters \\
\hline & COM10 & Parking (e.g., garages) \\
\hline \multirow{6}{*}{ Industrial } & IND1 & Heavy industry (e.g., factory) \\
\hline & IND2 & Light industry (e.g., factory) \\
\hline & IND3 & Food/drugs/chemicals (e.g., factory) \\
\hline & IND4 & Metals/minerals processing (e.g., factory) \\
\hline & IND5 & High technology (e.g., factory) \\
\hline & IND6 & Construction (e.g., office) \\
\hline Agricultural & AGR1 & Agriculture \\
\hline Religious & REL1 & Church/non-profit \\
\hline \multirow{2}{*}{ Governmental } & GOV1 & General services (e.g., office) \\
\hline & GOV2 & Emergency response (e.g., police/fire station/eoc) \\
\hline \multirow{2}{*}{ Educational } & EDU1 & Grade schools \\
\hline & EDU2 & Colleges/universities (does not include group housing) \\
\hline
\end{tabular}


medRxiv preprint doi: https://doi.org/10.1101/2020.05.14.20101311; this version posted May 20, 2020. The copyright holder for this preprint (which was not certified by peer review) is the author/funder, who has granted medRxiv a license to display the preprint in perpetuity.

It is made available under a CC-BY-ND 4.0 International license .

M Dillon and

Reducing Exposures to Airborne

R Sextro

Particles Through Improved Filtration

Table 2. Equation and corresponding parameter values associated with building use types. See [7] for a more detailed discussion of the building use types taken from HAZUS.

\begin{tabular}{|c|c|c|c|c|c|}
\hline $\begin{array}{l}\text { Building use } \\
\text { type (a) }\end{array}$ & $\begin{array}{c}\text { Building airflow } \\
\text { type }\end{array}$ & $\begin{array}{c}\text { R airflow } \\
\text { parameters } \\
\left(\Lambda_{\text {inf, }}, F_{r, f a n}, r_{\text {fan }}\right)(b) \\
\end{array}$ & $\begin{array}{c}\mathrm{H} \text { airflow } \\
\text { parameters } \\
\left(\mathrm{V}_{\mathrm{fan}}, \lambda_{\mathrm{T}}, \mathrm{F}_{\mathrm{oa}}\right)^{\text {(c) }} \\
\end{array}$ & $\begin{array}{c}\text { Deposition } \\
\text { adjustment } \\
\text { factor (d) }\end{array}$ & $\begin{array}{l}\text { Filtration } \\
\text { category (e) }\end{array}$ \\
\hline Outdoors (f) & $\mathrm{N} / \mathrm{A}$ & $\mathrm{N} / \mathrm{A}$ & $\mathrm{N} / \mathrm{A}$ & $\mathrm{N} / \mathrm{A}$ & $\mathrm{N} / \mathrm{A}$ \\
\hline RES1 & $\mathrm{R}$ & SFH & $N / A$ & 1 & Single family \\
\hline RES2 & $\mathrm{R}$ & $\mathrm{MH}$ & $\mathrm{N} / \mathrm{A}$ & 1.2 & Single family \\
\hline RES3A & $\mathrm{R}$ & SFH & $\mathrm{N} / \mathrm{A}$ & 1 & Single family \\
\hline RES3B & $\mathrm{R}, \mathrm{H}$ & APT w/o corridors & Apt w corridors & 1.2 & Low quality \\
\hline RES3C & $\mathrm{R}, \mathrm{H}$ & APT w/o corridors & Apt w corridors & 1.2 & Low quality \\
\hline RES3D & $\mathrm{R}, \mathrm{H}$ & APT w/o corridors & Apt w corridors & 1.2 & Low quality \\
\hline RES3E & $\mathrm{R}, \mathrm{H}$ & APT w/o corridors & Apt w corridors & 1 & Low quality \\
\hline RES3F & $\mathrm{R}, \mathrm{H}$ & APT w/o corridors & Apt w corridors & 1 & Low quality \\
\hline RES4 & $\mathrm{H}$ & $\mathrm{N} / \mathrm{A}$ & Hotel & 1 & Low quality \\
\hline RES5 & $\mathrm{H}$ & $\mathrm{N} / \mathrm{A}$ & Hotel & 1 & Low quality \\
\hline RES6 & $\mathrm{H}$ & $\mathrm{N} / \mathrm{A}$ & Hotel & 1 & Low quality \\
\hline COM1 & $\mathrm{H}$ & $\mathrm{N} / \mathrm{A}$ & Retail & 1 & Medium quality \\
\hline COM2 & $\mathrm{H}$ & $\mathrm{N} / \mathrm{A}$ & Warehouse & 0.6 & Low quality \\
\hline COM3 & $\mathrm{H}$ & $\mathrm{N} / \mathrm{A}$ & Retail & 1 & Low quality \\
\hline COM4 & $\mathrm{H}$ & $\mathrm{N} / \mathrm{A}$ & Office & 1 & Standard office \\
\hline COM5 & $\mathrm{H}$ & $\mathrm{N} / \mathrm{A}$ & Office & 1 & Standard office \\
\hline сом6 & $\mathrm{H}$ & $\mathrm{N} / \mathrm{A}$ & Health Care & 1 & Very high quality \\
\hline COM7 & $\mathrm{H}$ & $N / A$ & Health Care & 1 & Standard office \\
\hline COM8 & $\mathrm{H}$ & $\mathrm{N} / \mathrm{A}$ & Restaurant & 1 & Medium quality \\
\hline СОМ9 & $\mathrm{H}$ & $\mathrm{N} / \mathrm{A}$ & Retail & 1 & Medium quality \\
\hline COM10 (g) & $\mathrm{N} / \mathrm{A}$ & $\mathrm{N} / \mathrm{A}$ & $\mathrm{N} / \mathrm{A}$ & $\mathrm{N} / \mathrm{A}$ & $\mathrm{N} / \mathrm{A}$ \\
\hline IND1 & $\mathrm{H}$ & $\mathrm{N} / \mathrm{A}$ & Warehouse & 0.6 & Low quality \\
\hline IND2 & $\mathrm{H}$ & $N / A$ & Warehouse & 0.6 & Low quality \\
\hline IND3 & $\mathrm{H}$ & $\mathrm{N} / \mathrm{A}$ & Warehouse & 0.6 & High quality \\
\hline IND4 & $\mathrm{H}$ & $\mathrm{N} / \mathrm{A}$ & Warehouse & 0.6 & Low quality \\
\hline IND5 & $\mathrm{H}$ & $\mathrm{N} / \mathrm{A}$ & Warehouse & 0.6 & Very high quality \\
\hline IND6 & $\mathrm{H}$ & $\mathrm{N} / \mathrm{A}$ & Warehouse & 0.6 & Low quality \\
\hline AGR & $\mathrm{H}$ & $\mathrm{N} / \mathrm{A}$ & Warehouse & 0.6 & Low quality \\
\hline REL1 & $\mathrm{H}$ & $\mathrm{N} / \mathrm{A}$ & Retail & 1 & Low quality \\
\hline GoV1 & $\mathrm{H}$ & $\mathrm{N} / \mathrm{A}$ & Office & 1 & Standard office \\
\hline GOV2 & $\mathrm{H}$ & $\mathrm{N} / \mathrm{A}$ & Office & 1 & Medium quality \\
\hline EDU1 & $\mathrm{H}$ & $\mathrm{N} / \mathrm{A}$ & School & 1 & Medium quality \\
\hline EDU2 & $\mathrm{H}$ & $N / A$ & School & 1 & Medium quality \\
\hline
\end{tabular}

${ }^{(a)}$ HAZUS building occupancy type; ${ }^{(b)} \mathbf{R}=$ filtered recirculation. Values selected from the distributions defined in Table 3; ${ }^{\left({ }^{c}\right)} \mathbf{H}=$ HVAC system. Values selected from the distributions defined in Tables $\mathbf{3}$ to 6; this analysis, the outdoor protection factor and exit fraction is defined to be one (1); ${ }^{(\mathrm{g})}$ Not included in 344 the present analysis. 
medRxiv preprint doi: https://doi.org/10.1101/2020.05.14.20101311; this version posted May 20, 2020. The copyright holder for this preprint (which was not certified by peer review) is the author/funder, who has granted medRxiv a license to display the preprint in perpetuity. It is made available under a CC-BY-ND 4.0 International license .

M Dillon and

R Sextro
Reducing Exposures to Airborne Particles Through Improved Filtration

\subsection{Air Flow Parameters $\left(\lambda_{\text {inf, }}, F_{r}, f a n, r_{f a n}, v_{f a n}, \lambda_{T}, F_{o a}\right)$}

347 There are two mechanisms by which indoor and outdoor air is exchanged - via (largely)

348 uncontrolled infiltration and via controlled mechanical means (typically HVAC or exhaust fan

349 systems). For the single family residences, manufactured homes, duplexes, and apartments

350 without corridors (the RES1, RES2, RES3A, and a portion of the RES3B to RES3F HAZUS building

351 use types), Table 3 provides the natural air infiltration rate $\left(\lambda_{\text {inf }}\right)$, furnace recirculation fan duty

352 cycle $\left(F_{r, f a n}\right)$, and furnace system recirculation rate $\left(r_{f a n}\right)$ appropriate for scenarios in which

353 windows and doors are closed. The reported geometric standard deviation accounts for

354 variation in homes across the US and for the different seasons and times of the day.

Table 3. Select parameters used in $\mathbf{R}$ type airflow equations (filtered recirculation). These parameters assume a log-normal distribution.

\begin{tabular}{|c|c|c|c|}
\hline Parameter & $\begin{array}{c}\text { Geometric mean } \\
\text { (units) }\end{array}$ & $\begin{array}{c}\text { Geometric standard } \\
\text { deviation } \\
\text { (dimensionless) }\end{array}$ & Reference \\
\hline$\lambda_{\text {inf }}-\mathrm{SFH}{ }^{(\mathrm{a})}$ & $0.44\left(h^{-1}\right)$ & 2.04 & {$[14],[15]$} \\
\hline$\lambda_{\text {inf }}-\mathrm{MH}^{(\mathrm{a})}$ & $0.42\left(h^{-1}\right)$ & 1.86 & {$[14]$} \\
\hline$\lambda_{\text {inf }}$ - APT w/o corridors ${ }^{(\mathrm{a})}$ & $0.23\left(h^{-1}\right)$ & 1.82 & {$[14]$} \\
\hline$r_{\text {fan }}$ & $5.7\left(h^{-1}\right)$ & 1.26 & [15] \\
\hline $\begin{array}{c}F_{r, \text { fan }} \\
\text { (baseline scenario) }\end{array}$ & $\begin{array}{c}0.25 \\
\text { (dimensionless) }\end{array}$ & 1.85 & [15] \\
\hline $\begin{array}{c}F_{r, \text { fan }} \\
\text { (Min MERV } 7 \text { scenario) }\end{array}$ & $\begin{array}{c}1 \\
\text { (dimensionless) }\end{array}$ & 1.0 & N/A \\
\hline $\begin{array}{c}\mathrm{F}_{\mathrm{r}, \text { fan }} \\
\text { (Min MERV } 11 \text { scenario) }\end{array}$ & $\begin{array}{c}1 \\
\text { (dimensionless) }\end{array}$ & 1.0 & N/A \\
\hline $\begin{array}{c}F_{r, \text { fan }} \\
\text { (Min MERV } 14 \text { scenario) }\end{array}$ & $\begin{array}{c}1 \\
\text { (dimensionless) }\end{array}$ & 1.0 & N/A \\
\hline
\end{tabular}

(a) This parameter value assumes doors and windows are closed.

$359 \mathrm{SFH}=$ single family home (used for RES1 and RES3A)

$360 \mathrm{MH}=$ manufactured home (used for RES2)

361 APT w/o corridors = multifamily dwelling buildings that do NOT have corridors (RES3B to RES3F w/o $362 \quad$ corridors) 
medRxiv preprint doi: https://doi.org/10.1101/2020.05.14.20101311; this version posted May 20, 2020. The copyright holder for this preprint (which was not certified by peer review) is the author/funder, who has granted medRxiv a license to display the preprint in perpetuity. It is made available under a CC-BY-ND 4.0 International license.

M Dillon and

R Sextro

Reducing Exposures to Airborne Particles Through Improved Filtration

364 Table 4 provides our estimates for the average, minimum, and maximum values for the $\lambda_{\text {inf }}, v_{\text {fan }}$,

$365 F_{o a}$, and $\lambda_{T}$ parameters for 9 representative US building types or subtypes: Restaurants, Offices,

366 Schools, Retail, Health Care, Hotels (guest rooms and common spaces), Apartments with

367 corridors, and Warehouses. [7] derives and discusses these values. As we lack a robust estimate

368 for the functional form of the probability distribution, we assume a triangular distribution for

369 each parameter.

370 For each of the given HAZUS apartment building use types (RES3B to RES3F), there is a mixture

371 of buildings with and without internal corridors. We estimate the key building parameter

372 metrics by combining both building types using the building height as a proxy for the presence

373 of a corridor: apartment buildings greater than 3 stories are assumed to have interior corridors

374 and apartment buildings less than 3 stories do not have them ( 3 story buildings were not

375 included in the reference dataset) [14]. For the latter, we use the $\mathbf{R}$ equations as described in

376 the prior paragraph. For the former, we use the $\mathbf{H}$ equations to incorporate a mechanical means

377 of supplying air to the internal corridors, following Persily et al. [16]. Table 5 gives the

378 percentile distributions for the total building air ventilation rates for apartments that do have

379 corridors. Table 6 summarizes the fraction of buildings in each category by HAZUS building

380 type.

381 Hotels (RES4), and presumably other institutional residential buildings such as dormitories and

382 nursing homes (RES5 and RES6), can have different air handling mechanisms in the common

383 use spaces (e.g., lobby, restaurants/dining areas, corridors) compared to the sleeping areas

384 (e.g., guest rooms). As discussed in [7], there is minimal mixing between these two regions, and

385 so we develop two, independent sets of building protection estimates - one for guest rooms

386 and the other for the rest of the building, see Table 4. We note that the population in these two

387 building areas varies by the time of day - with nearly all people in the guest room at night and

388 more evenly distributed throughout the building during the day [17]. As a result, the

389 appropriate building protection factors vary by time of day. 
medRxiv preprint doi: https://doi.org/10.1101/2020.05.14.20101311; this version posted May 20, 2020. The copyright holder for this preprint (which was not certified by peer review) is the author/funder, who has granted medRxiv a license to display the preprint in perpetuity.

It is made available under a CC-BY-ND 4.0 International license .

M Dillon and

R Sextro
Reducing Exposures to Airborne

Particles Through Improved Filtration

Table 4. Select parameters used in $\mathrm{H}$ type airflow equations (active HVAC). These parameters

392 assume a triangular distribution. See [7] for more details.

\begin{tabular}{|c|c|c|c|}
\hline & average & maximum & minimum \\
\hline \multicolumn{4}{|c|}{ supply fan rate, $v_{\text {fan }}\left(\mathrm{h}^{-1}\right)$} \\
\hline Restaurant & 7.0 & 13 & 6.1 \\
\hline Office & 3.8 & 25 & 1.1 \\
\hline School & 3.1 & 11 & 2.8 \\
\hline Retail & 3.7 & 9.1 & 2.0 \\
\hline Health care & 5.8 & 18 & 3.9 \\
\hline Warehouse & 0.9 & 1.0 & 0.6 \\
\hline Hotel, guest rooms & 1.0 & 1.4 & 0.6 \\
\hline Hotel, common spaces & 4.2 & 6.6 & 1.9 \\
\hline Apt w corridors & 7.4 & 7.6 & 7.2 \\
\hline \multicolumn{4}{|c|}{ fraction of outside air entering the building, $F_{o a}$ (dimensionless) } \\
\hline Restaurant & 0.5 & 0.7 & 0.0 \\
\hline Office & 0.1 & 1.0 & 0.0 \\
\hline School & 0.2 & 0.6 & 0.1 \\
\hline Retail & 0.1 & 0.6 & 0.0 \\
\hline Health care & 0.1 & 0.2 & 0.1 \\
\hline Warehouse & 0.05 & 0.06 & 0.04 \\
\hline Hotel, guest rooms & 1.0 & 1.0 & 1.0 \\
\hline Hotel, common spaces & 0.13 & 0.17 & 0.09 \\
\hline Apt w corridors & 0.05 & 0.08 & 0.02 \\
\hline \multicolumn{4}{|c|}{ natural air infiltration rate, $\lambda_{\text {inf }}\left(\mathrm{h}^{-1}\right)$} \\
\hline Restaurant & 0.5 & 1.9 & 0.01 \\
\hline Office & 0.12 & 1.2 & 0.0 \\
\hline School & 0.3 & 1.2 & 0.02 \\
\hline Retail & 0.2 & 0.8 & 0.0 \\
\hline Health care & 0.05 & 0.9 & 0.0 \\
\hline Warehouse & 0.3 & 1.0 & 0.05 \\
\hline Hotel, guest rooms & 0.0 & 0.0 & 0.0 \\
\hline Hotel, common spaces ${ }^{(a)}$ & 0.3 & 1.2 & 0.0 \\
\hline Apt w corridors & \multicolumn{3}{|c|}{$\lambda_{T}-v_{f a n} \cdot F_{o a}\left(\right.$ see Table 5 for $\left.\lambda_{T}\right)$} \\
\hline
\end{tabular}

(a) Assumes infiltration rates are the same for the (i) other rooms and (ii) whole building

395 Table 5. Percentile distribution for the total building air ventilation rate, $\lambda_{T}\left(\mathrm{~h}^{-1}\right)$

396 for Apartments that DO have Corridors (RES3B-F) from [14].

\begin{tabular}{|lllllll|}
\hline $\mathbf{P}_{1 \%}$ & $\mathbf{P}_{5 \%}$ & $\mathbf{P}_{25 \%}$ & $\mathbf{P}_{50 \%}$ & $\mathbf{P}_{75 \%}$ & $\mathbf{P}_{95 \%}$ & $\mathbf{P}_{99 \%}$ \\
\hline 0.23 & 0.33 & 0.42 & 0.46 & 0.54 & 0.71 & 0.87 \\
\hline
\end{tabular}


medRxiv preprint doi: https://doi.org/10.1101/2020.05.14.20101311; this version posted May 20, 2020. The copyright holder for this preprint (which was not certified by peer review) is the author/funder, who has granted medRxiv a license to display the preprint in perpetuity.

It is made available under a CC-BY-ND 4.0 International license .

M Dillon and

R Sextro
Reducing Exposures to Airborne

Particles Through Improved Filtration

Table 6. Fraction of apartment buildings by HAZUS building use type that are either less than or greater than 3 stories in height (from [16]).

\begin{tabular}{|cccc|}
\hline $\begin{array}{c}\text { HAZUS } \\
\text { building use } \\
\text { type }\end{array}$ & $\begin{array}{c}\text { HAZUS building use type } \\
\text { description }\end{array}$ & $\begin{array}{c}\text { Fraction of buildings } \\
\text { less than } \mathbf{3} \text { stories } \\
\text { (dimensionless) }\end{array}$ & $\begin{array}{c}\text { Fraction of buildings } \\
\text { greater than } \mathbf{3} \text { stories } \\
\text { (dimensionless) }\end{array}$ \\
\hline RES3B $^{\text {(a) }}$ & Multi-family dwelling: 3-4 units & 0.87 & 0.13 \\
RES3C & Multi-family dwelling: 5-9 units & 0.80 & 0.20 \\
RES3D & Multi-family dwelling: 10-19 units & 0.60 & 0.40 \\
RES3E $^{\text {(b) }}$ & Multi-family dwelling: 20-49 units & 0.24 & 0.76 \\
RES3F $^{\text {(c) }}$ & Multi-family dwelling: 50+ units & 0.10 & 0.90 \\
\hline
\end{tabular}

a) Persily et al. [16] results correspond to buildings with 2 to 4 units.

(b) Persily et al. [16] results correspond to buildings with 20 to 39 units.

(c) Persily et al. [16] results correspond to buildings with $40+$ units.

\subsection{Particle Size Specific Parameters $\left(\lambda_{\text {dep }}, L_{\text {inf, }}, F_{\text {filter }}\right)$}

Indoor particle concentrations are affected by three parameters: deposition to indoor surfaces, losses that occur when airborne particles penetrate through the building envelope, and losses that occur during filtration. Particle deposition loss rates are primarily controlled by particle size, the indoor surface to volume ratio, and, to some extent, turbulence conditions within a given space. We treat airborne particles as chemically inert, with negligible thermophoretic or electrostatic interactions with indoor surfaces in buildings. Table 7 provides the particle deposition loss rate distributions for residential buildings and is based on experiments conducted in actual homes or room-sized chambers. There are almost no comparable, sizeresolved particle deposition rate data reported for other building types. For these buildings, we have used the residential loss rates and, for some cases, multiplied the residential loss rates by our estimated deposition adjustment factor. This factor is based on our estimates of the differences in surface-to-volume ratios in those buildings compared with those in residences and accounts for the quantity and type of furnishings. These factors are shown in the next to the last column of Table 2.

Table 7. Cumulative frequency distribution of airborne particle deposition loss rates in buildings $\left(\lambda_{\text {dep, }}\right.$ $\mathrm{h}^{-1}$ ) by particle size (aerodynamic diameter). See [7] for more details.

\begin{tabular}{|cccccccc|}
\hline $\begin{array}{c}\text { Airborne } \\
\text { particle size }\end{array}$ & \multicolumn{6}{c}{ Percentile distribution for the indoor deposition particle loss rate $\left(\boldsymbol{\lambda}_{\text {dep }}, \mathbf{h}^{\mathbf{- 1}}\right)$} \\
$(\boldsymbol{\mu m})$ & $\mathbf{P}_{\mathbf{1}}$ & $\mathbf{P}_{\mathbf{5}}$ & $\mathbf{P}_{\mathbf{2 5} \%}$ & $\mathbf{P}_{\mathbf{5 0} \%}$ & $\mathbf{P}_{\mathbf{7 5} \%}$ & $\mathbf{P}_{\mathbf{9 5 \%}}$ & $\mathbf{P}_{99 \%}$ \\
\hline $\mathbf{0 . 1}$ & 0.07 & 0.07 & 0.39 & 0.59 & 0.72 & 1.57 & 1.67 \\
$\mathbf{0 . 3}$ & 0.02 & 0.11 & 0.27 & 0.46 & 0.93 & 1.31 & 1.35 \\
$\mathbf{1}$ & 0.04 & 0.15 & 0.28 & 0.40 & 0.89 & 2.39 & 2.68 \\
$\mathbf{3}$ & 0.05 & 0.31 & 0.72 & 1.31 & 1.87 & 3.60 & 3.89 \\
$\mathbf{1 0}$ & 0.08 & 0.08 & 1.83 & 4.12 & 6.78 & 10.83 & 11.45 \\
\hline
\end{tabular}


medRxiv preprint doi: https://doi.org/10.1101/2020.05.14.20101311; this version posted May 20, 2020. The copyright holder for this preprint (which was not certified by peer review) is the author/funder, who has granted medRxiv a license to display the preprint in perpetuity. It is made available under a CC-BY-ND 4.0 International license .

M Dillon and

R Sextro
Reducing Exposures to Airborne Particles Through Improved Filtration

422 Airflow pathways into buildings depend upon a number of building features, primary among

423 them is whether the building has an HVAC system, as most commercial buildings do. Residential

424 buildings, on the other hand, largely do not and thus the major airflow pathway is infiltration

425 through cracks and penetrations in the building shell. As discussed in greater detail in [7],

426 particle losses are parameterized by the particle penetration efficiency, which is particle-size-

427 dependent; values for these parameters are presented in Table $\mathbf{8}$ and are used here for all

428 building types.

Table 8. Cumulative frequency distribution of the building particle penetration efficiency $\left(L_{i n f}\right.$, dimensionless) by particle size (aerodynamic diameter). See [7] for more details.

\begin{tabular}{|cccccccc|}
\hline $\begin{array}{c}\text { Airborne } \\
\text { particle size } \\
(\boldsymbol{\mu m})\end{array}$ & \multicolumn{6}{c}{ Percentile distribution for the particle penetration efficiency } & ( $\boldsymbol{L}_{\text {inf }}$, dimensionless) \\
\hline $\mathbf{0 . 1}$ & $\mathbf{P}_{\mathbf{1}}$ & $\mathbf{P}_{\mathbf{5}}$ & $\mathbf{P}_{\mathbf{2 5}}$ & $\mathbf{P}_{\mathbf{5 0}}$ & $\mathbf{P}_{\mathbf{7 5} \%}$ & $\mathbf{P}_{\mathbf{9 5 \%}}$ & $\mathbf{P}_{\mathbf{9 9}}$ \\
$\mathbf{0 . 3}$ & 0.52 & 0.52 & 0.55 & 0.63 & 0.69 & 1.02 & 1.04 \\
$\mathbf{1}$ & 0.51 & 0.51 & 0.64 & 0.72 & 0.83 & 0.97 & 0.99 \\
$\mathbf{3}$ & 0.56 & 0.59 & 0.80 & 0.94 & 0.99 & 1.02 & 1.03 \\
$\mathbf{1 0}$ & 0.27 & 0.34 & 0.50 & 0.69 & 0.83 & 0.95 & 0.97 \\
& 0.09 & 0.09 & 0.17 & 0.42 & 0.56 & 0.84 & 0.87 \\
\hline
\end{tabular}

433 For buildings with HVAC systems, a major pathway for outdoor air entering the building is 434 through the mechanical air handling system which typically contains some particle filtration 435 capability. As discussed in [7], the performance of these particle filters is typically categorized 436 by their Minimum Efficiency Reporting Value (MERV) rating, as specified by ASHRAE [18]. MERV 437 ratings correspond to the fraction of airborne particles captured in a single pass through the 438 filter. Filters with numerically larger MERV ratings are more efficient at removing airborne 439 particles than filters with numerically smaller MERV ratings. For our purposes here, we consider 4406 filtration categories - single family, standard office, low quality, medium quality, high quality, 441 and very high quality - each with a different distribution of filter MERV ratings. For our baseline 442 scenario calculation purposes, we assign each HAZUS building use type the filtration category 443 corresponding to our estimated distribution of the filter media types and quality that are in 444 general use (see last column in Table 2).

445 As we are analyzing the effects of improved filtration efficiency, the filtration category specific 446 distribution of MERV rated filters varies for each scenario analyzed as shown in Table 9. The 447 baseline scenario distribution is compatible with prior literature surveys of US building filtration 448 efficiency and is discussed in [7]. The other three scenarios assume that the currently existing 449 lower efficiency furnace and HVAC filters are replaced with progressively higher efficiency 450 filters. The difference between the latter three scenarios is the minimum filter rating 451 considered. The Minimum MERV 7 scenario replaces all filters with MERV ratings below MERV 7 
medRxiv preprint doi: https://doi.org/10.1101/2020.05.14.20101311; this version posted May 20, 2020. The copyright holder for this preprint (which was not certified by peer review) is the author/funder, who has granted medRxiv a license to display the preprint in perpetuity. It is made available under a CC-BY-ND 4.0 International license .

M Dillon and

R Sextro

Reducing Exposures to Airborne Particles Through Improved Filtration

452 with a MERV 7 or 8 filter (other filters are not changed). The Minimum MERV 11 scenario

453 replaces all filters with a MERV rating below 11 with a MERV 11 or 12 filter (other filters are not

454 changed). The Minimum MERV 14 scenario replaces all filters with a MERV rating below 14 with

455 a MERV 14 or 15 rated filter. We note that $35 \%$ of single family homes do not have recirculating

456 air furnaces - e.g., radiators, in-wall heaters - and so their building filtration remains

457 unchanged in all scenarios. The computed results for each filtration scenario include these

458 homes.

459 For each MERV filter rating shown in Table 9, Table 10 provides the single pass filtration

460 efficiency distributions which, for each MERV rating, considers the efficiency variation both (a)

461 within similarly rated filters and (b) due to filter loading over the filter lifetime (note, our

462 filtration parameters are for media-type filters). See [7] for more details.

463 
medRxiv preprint doi: https://doi.org/10.1101/2020.05.14.20101311; this version posted May 20, 2020. The copyright holder for this preprint (which was not certified by peer review) is the author/funder, who has granted medRxiv a license to display the preprint in perpetuity.

It is made available under a CC-BY-ND 4.0 International license .

M Dillon and

R Sextro
Reducing Exposures to Airborne

Particles Through Improved Filtration

Table 9. Distributions of MERV-rated filters by building use type filtration categories for the baseline

[7] and for the improved filtration (Minimum MERV) analysis scenarios.

\begin{tabular}{|c|c|c|c|c|c|c|c|}
\hline \multirow{2}{*}{$\begin{array}{l}\text { Analysis } \\
\text { Scenario }\end{array}$} & \multirow{2}{*}{$\begin{array}{l}\text { Building Use Type } \\
\text { Filtration Category }\end{array}$} & \multicolumn{6}{|c|}{ MERV Distribution Fractions (dimensionless) } \\
\hline & & $\begin{array}{l}\text { No } \\
\text { Filter }\end{array}$ & $\underset{\text { (b) }}{\text { MERVO }}$ & MERV5 & $\begin{array}{l}\text { MERV7 to } \\
\text { MERV8 (c) }\end{array}$ & $\begin{array}{l}\text { MERV11 to } \\
\text { MERV12 }\end{array}$ & $\begin{array}{l}\text { MERV14 to } \\
\text { MERV15 (c) }\end{array}$ \\
\hline \multirow{6}{*}{ 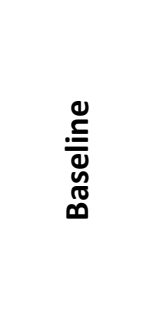 } & Single family (a) & 0.35 & 0.16 & 0.20 & 0.20 & 0.07 & 0.03 \\
\hline & Standard office & 0.00 & 0.00 & 0.20 & 0.55 & 0.10 & 0.15 \\
\hline & Low quality & 0.00 & 0.00 & 0.65 & 0.30 & 0.05 & 0.00 \\
\hline & Medium quality & 0.00 & 0.00 & 0.45 & 0.45 & 0.05 & 0.05 \\
\hline & High quality & 0.00 & 0.00 & 0.00 & 0.25 & 0.50 & 0.25 \\
\hline & Very high quality & 0.00 & 0.00 & 0.00 & 0.00 & 0.00 & 1.00 \\
\hline \multirow{6}{*}{ 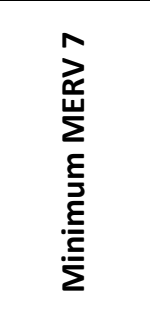 } & Single family (a) & 0.35 & 0.00 & 0.00 & 0.55 & 0.07 & 0.03 \\
\hline & Standard office & 0.00 & 0.00 & 0.00 & 0.75 & 0.10 & 0.15 \\
\hline & Low quality & 0.00 & 0.00 & 0.00 & 0.95 & 0.05 & 0.00 \\
\hline & Medium quality & 0.00 & 0.00 & 0.00 & 0.90 & 0.05 & 0.05 \\
\hline & High quality & 0.00 & 0.00 & 0.00 & 0.25 & 0.50 & 0.25 \\
\hline & Very high quality & 0.00 & 0.00 & 0.00 & 0.00 & 0.00 & 1.00 \\
\hline \multirow{6}{*}{ 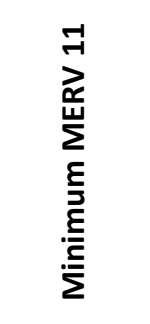 } & Single family ${ }^{(a)}$ & 0.35 & 0.00 & 0.00 & 0.00 & 0.62 & 0.03 \\
\hline & Standard office & 0.00 & 0.00 & 0.00 & 0.00 & 0.85 & 0.15 \\
\hline & Low quality & 0.00 & 0.00 & 0.00 & 0.00 & 1.00 & 0.00 \\
\hline & Medium quality & 0.00 & 0.00 & 0.00 & 0.00 & 0.95 & 0.05 \\
\hline & High quality & 0.00 & 0.00 & 0.00 & 0.00 & 0.75 & 0.25 \\
\hline & Very high quality & 0.00 & 0.00 & 0.00 & 0.00 & 0.00 & 1.00 \\
\hline \multirow{6}{*}{ 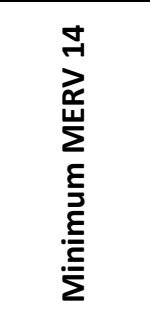 } & Single family (a) & 0.35 & 0.00 & 0.00 & 0.00 & 0.00 & 0.65 \\
\hline & Standard office & 0.00 & 0.00 & 0.00 & 0.00 & 0.00 & 1.00 \\
\hline & Low quality & 0.00 & 0.00 & 0.00 & 0.00 & 0.00 & 1.00 \\
\hline & Medium quality & 0.00 & 0.00 & 0.00 & 0.00 & 0.00 & 1.00 \\
\hline & High quality & 0.00 & 0.00 & 0.00 & 0.00 & 0.00 & 1.00 \\
\hline & Very high quality & 0.00 & 0.00 & 0.00 & 0.00 & 0.00 & 1.00 \\
\hline
\end{tabular}

466 (a) This distribution includes both the MERV filter rating distribution for the $65 \%$ of US homes with furnace/AC systems as well as the $35 \%$ of the US homes that lack a HVAC system (no filter). $F_{\text {filter }}$ for the no filter homes is 0 .

(b) Indicates that the system is capable of having a filter, but the filter is absent.

(c) We have combined filtration efficiencies for 2 MERV ratings when considering these categories.

Analysis Scenarios: Baseline scenario represents estimated current US filter usage. Minimum MERV scenarios show how overall US building filtration capability improves assuming that all buildings with forced air systems use a filter equal to or greater than the stated MERV rating. 
medRxiv preprint doi: https://doi.org/10.1101/2020.05.14.20101311; this version posted May 20, 2020. The copyright holder for this preprint (which was not certified by peer review) is the author/funder, who has granted medRxiv a license to display the preprint in perpetuity.

It is made available under a CC-BY-ND 4.0 International license .

M Dillon and

R Sextro
Reducing Exposures to Airborne

Particles Through Improved Filtration
475

476

Table 10. Filtration efficiency $\left(\boldsymbol{F}_{\text {filter }}\right.$, dimensionless) by air filter MERV rating and particle size. See [7] for more details.

\begin{tabular}{|c|c|c|c|c|c|c|c|c|}
\hline \multirow{2}{*}{$\begin{array}{l}\text { Air-filter } \\
\text { MERV } \\
\text { rating }\end{array}$} & \multirow{2}{*}{$\begin{array}{c}\text { Airborne } \\
\text { particle size } \\
(\mu \mathrm{m})\end{array}$} & \multicolumn{7}{|c|}{ Percentile distribution for the filtration efficiency ( $F_{\text {filter }}$, dimensionless) } \\
\hline & & $\mathbf{P}_{1 \%}$ & $\mathbf{P}_{5 \%}$ & $\mathbf{P}_{25 \%}$ & $\mathbf{P}_{50 \%}$ & $\mathbf{P}_{75 \%}$ & $\mathbf{P}_{95 \%}$ & $\mathbf{P}_{99 \%}$ \\
\hline \multirow{5}{*}{0} & 0.1 & 0 & 0 & 0 & 0 & 0 & 0 & 0 \\
\hline & 0.3 & 0 & 0 & 0 & 0 & 0 & 0 & 0 \\
\hline & 1 & 0 & 0 & 0 & 0 & 0 & 0 & 0 \\
\hline & 3 & 0 & 0 & 0 & 0 & 0 & 0 & 0 \\
\hline & 10 & 0 & 0 & 0 & 0 & 0 & 0 & 0 \\
\hline \multirow{5}{*}{5} & 0.1 & 0.00 & 0.00 & 0.00 & 0.01 & 0.04 & 0.18 & 0.29 \\
\hline & 0.3 & 0.00 & 0.00 & 0.00 & 0.01 & 0.04 & 0.18 & 0.29 \\
\hline & 1 & 0.05 & 0.05 & 0.07 & 0.10 & 0.18 & 0.69 & 0.83 \\
\hline & 3 & 0.28 & 0.28 & 0.32 & 0.40 & 0.64 & 0.95 & 0.98 \\
\hline & 10 & 0.22 & 0.22 & 0.29 & 0.45 & 0.83 & 0.94 & 0.98 \\
\hline \multirow{5}{*}{7 to 8} & 0.1 & 0.03 & 0.03 & 0.12 & 0.20 & 0.24 & 0.33 & 0.37 \\
\hline & 0.3 & 0.03 & 0.03 & 0.12 & 0.20 & 0.24 & 0.33 & 0.37 \\
\hline & 1 & 0.15 & 0.27 & 0.51 & 0.69 & 0.81 & 0.90 & 0.92 \\
\hline & 3 & 0.51 & 0.58 & 0.93 & 0.96 & 0.98 & 0.99 & 1.00 \\
\hline & 10 & 0.61 & 0.62 & 0.95 & 0.99 & 1.00 & 1.00 & 1.00 \\
\hline \multirow{5}{*}{11 to 12} & 0.1 & 0.04 & 0.04 & 0.07 & 0.40 & 0.56 & 0.92 & 0.94 \\
\hline & 0.3 & 0.04 & 0.04 & 0.07 & 0.40 & 0.56 & 0.92 & 0.94 \\
\hline & 1 & 0.22 & 0.25 & 0.42 & 0.76 & 0.91 & 0.99 & 0.99 \\
\hline & 3 & 0.67 & 0.68 & 0.87 & 0.95 & 0.99 & 1.00 & 1.00 \\
\hline & 10 & 0.67 & 0.67 & 0.85 & 0.98 & 1.00 & 1.00 & 1.00 \\
\hline \multirow{5}{*}{14 to 15} & 0.1 & 0.64 & 0.68 & 0.80 & 0.86 & 0.92 & 0.99 & 0.99 \\
\hline & 0.3 & 0.64 & 0.68 & 0.80 & 0.86 & 0.92 & 0.99 & 0.99 \\
\hline & 1 & 0.86 & 0.90 & 0.96 & 0.98 & 0.99 & 1.00 & 1.00 \\
\hline & 3 & 0.98 & 0.99 & 0.99 & 1.00 & 1.00 & 1.00 & 1.00 \\
\hline & 10 & 0.99 & 0.99 & 1.00 & 1.00 & 1.00 & 1.00 & 1.00 \\
\hline
\end{tabular}


medRxiv preprint doi: https://doi.org/10.1101/2020.05.14.20101311; this version posted May 20, 2020. The copyright holder for this preprint (which was not certified by peer review) is the author/funder, who has granted medRxiv a license to display the preprint in perpetuity. It is made available under a CC-BY-ND 4.0 International license .

M Dillon and

R Sextro
Reducing Exposures to Airborne Particles Through Improved Filtration

\section{Results}

479 Using the equations, input assumptions, and data described in the previous two sections, we 480 estimate the benefits of improving building filtration efficiency using off-the-shelf air filter 481 technology across 32 of the 33 major FEMA HAZUS building use types shown in Table 1. In this 482 section we present these benefits by comparing three improved filtration scenarios, each with 483 increasingly higher minimum filtration efficiency, against a baseline scenario, which reflects our 484 understanding of the existing filtration distribution in the US building stock and normal furnace operating conditions. Three primary metrics are considered here: (1) the passive protection provided by buildings against outdoor airborne particulate hazards (Building Transmission Factor), (2) the degree to which indoor individuals are exposed to indoor-origin airborne particles (Indoor Normalized TSIAC) and (3) the fraction of indoor airborne particles that exit the building and enter the outdoor atmosphere (Building Exit Fraction). We also discuss the potential improvement on regional exposures due to particles exiting the building and exposing downwind building occupants. For each of the 32 building use types, our modeling covers five aerosol sizes $\left(0.1,0.3,1,3,10 \mu \mathrm{m}\right.$ diameter) and four airborne loss rates $\left(0,0.1,1,10 \mathrm{hr}^{-1}\right)$. The entire set of results are provided in Supplemental Material A: Detailed Results.

494 We focus the discussion of these results on six common building types, two aerosols sizes ( $1 \mu \mathrm{m}$ and $3 \mu \mathrm{m}$ aerodynamic diameter), an airborne aerosol decay rate of $0 \mathrm{hr}^{-1}$, and the US average (expectation value) result for each building metric. The six building types consist of three residential building categories: single family houses (RES1), small apartment buildings with 3 to 9 units (average of RES3B and RES3C), and large apartment buildings with 20 to $50+$ units (average of RES3E and RES3F). It is important to note that the modeling results for the two types of apartment buildings are based on combinations of buildings with different air handling systems. The three non-residential building categories are: retail stores (COM1), office buildings (average of COM4, COM5 and GOV1), and schools (EDU1).

503 Results are presented graphically for the baseline scenario and then as the fractional 504 improvements resulting from better filtration. Summary tables are provided in Supplemental Material B: Results Summary. Additional figures showing the improved filtration scenario results are provided in Supplemental Material C: Additional Building Metric Figures. Finally, the systematic influence of particle size and airborne decay rate on the improvement ratio for the Building Transmission Factor is illustrated for MERV 14-15 filters in Supplemental Material

\section{D: Improvement Sensitivity to Particle Size and Airborne Loss Rate.} each metric and filter scenario we have presented the average results from $~ 10,000$ Monte

512 Carlo modeling runs because average values are commonly used in air quality exposure and 
medRxiv preprint doi: https://doi.org/10.1101/2020.05.14.20101311; this version posted May 20, 2020. The copyright holder for this preprint (which was not certified by peer review) is the author/funder, who has granted medRxiv a license to display the preprint in perpetuity. It is made available under a CC-BY-ND 4.0 International license .

M Dillon and

R Sextro

Reducing Exposures to Airborne Particles Through Improved Filtration

513 health impact assessments. The corresponding modeling uncertainty in the mean value, the

514 standard error, is a few percent. In contrast, robust estimates of the input parameter

515 uncertainty are not available, see [7] for more detail, and so result uncertainty due to input

516 parameter uncertainty was not generated. The model outputs shown in Supplemental Material

517 A: Detailed Results are presented as the averages of five equally sized bins into which the

518 model results are aggregated. These bins range from the lowest $20 \%$ of the model results to the

519 highest $20 \%$ and so provide an estimate of the overall result variability. In most cases, this

520 variation is within a factor of 1.5 to 4 of the average value. 
medRxiv preprint doi: https://doi.org/10.1101/2020.05.14.20101311; this version posted May 20, 2020. The copyright holder for this preprint (which was not certified by peer review) is the author/funder, who has granted medRxiv a license to display the preprint in perpetuity.

It is made available under a CC-BY-ND 4.0 International license .

M Dillon and

R Sextro
Reducing Exposures to Airborne

Particles Through Improved Filtration

5.1. Reducing Indoor Exposures to Outdoor Airborne Particles (Building Transmission

524 The baseline Building Transmission Factor results, shown in Figure 1, reflect our estimates of the ratio of the indoor exposures to the corresponding outdoor exposure for the existing filtration distribution and normal furnace operating conditions for the 6 common US building types we have chosen to highlight. There is a wide range of Building Transmission Factor estimates, with the best protection (lowest ratios) for apartments. For most small apartment buildings, infiltration rates are small, and so the source term (numerator) in Equation $\mathbf{3 R}$ is small, see Table 3. For most large apartments buildings, our analysis assumes an active HVAC system (Equation $\mathbf{3 H}$ ), with a relatively larger recirculation rate, see Table 4. In general, buildings provide more protection against $3 \mu \mathrm{m}$ diameter aerosols, as compared to $1 \mu \mathrm{m}$ diameter aerosols, mainly due to higher filtration efficiencies for the larger particles - even for lower efficiency filters - and higher indoor deposition loss rates.

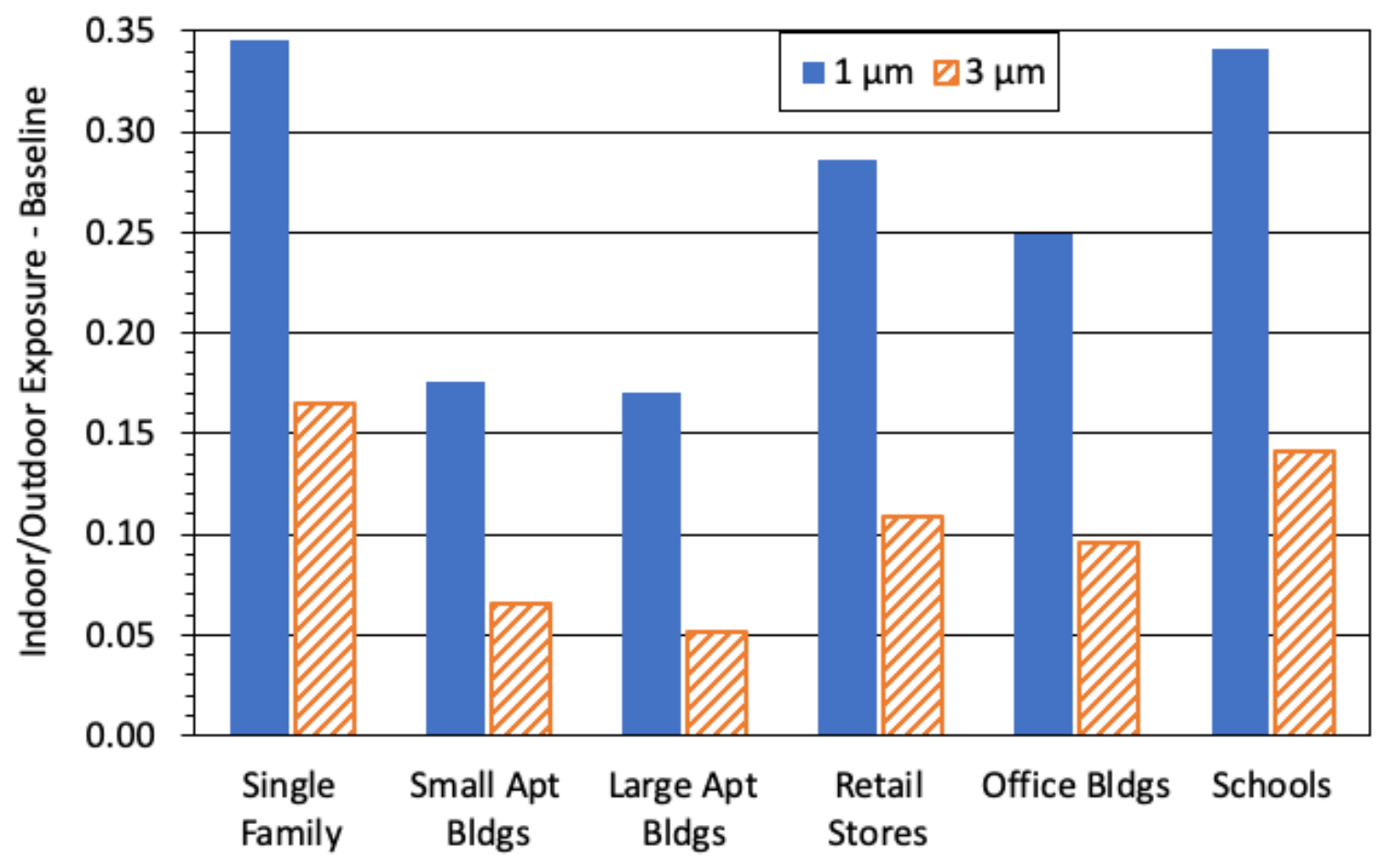

Figure 1. Baseline scenario results for the US Building Transmission Factors (dimensionless) the ratio of the indoor exposures to the corresponding outdoor exposure - for selected building types; and two aerosol sizes: $1 \mu \mathrm{m}$ (solid bar) and $3 \mu \mathrm{m}$ diameter (diagonal striped bar). Higher Building Transmission Factor values indicate more exposure. 
medRxiv preprint doi: https://doi.org/10.1101/2020.05.14.20101311; this version posted May 20, 2020. The copyright holder for this preprint (which was not certified by peer review) is the author/funder, who has granted medRxiv a license to display the preprint in perpetuity. It is made available under a CC-BY-ND 4.0 International license .

M Dillon and

R Sextro

Reducing Exposures to Airborne Particles Through Improved Filtration

540 Figure 2 presents the improvement associated with higher efficiency filtration using the ratio of

541 Building Transmission Factor for the baseline scenario compared to the specified improved

542 filtration scenario for selected residential and non-residential buildings. A value of 1 on the

543 vertical axis indicates no improvement over the baseline scenario. A factor of 2 means that the

544 improved filtration scenario results in half the Building Transmission Factor (and thus half the

545 indoor exposure) relative to the baseline scenario. Recall that improved filtration scenarios

546 assume the furnace fan duty cycle is increased to $100 \%$ (always on) in those buildings with

547 forced air heating/cooling systems. Figure $\mathbf{2}$ shows that for all building types, scenarios using a

548 MERV 7 or greater filter provide at least a 35\% reduction in indoor exposures for $1 \mu \mathrm{m}$ and 3

$549 \mu \mathrm{m}$ diameter particles. The reductions in indoor exposures vary by building type, minimum

$550 \quad$ MERV filter rating, and particle size.

551 Figure 2 (top panel) shows that for single family dwellings, the progression across the improved 552 filtration scenarios yields a factor of $1.6 x$ to $1.8 x$ improvement for the two particle sizes shown

553 (i.e., $\sim 40 \%$ reduction in indoor exposures). For apartments, the magnitude of the improvement

554 is larger, a factor of $2.5 x$ to $3.2 x$ ( $~ 65 \%$ reduction) for the Minimum MERV 7 and Minimum

555 MERV 11 scenarios. For large apartments, an even greater improvement occurs with the use of

556 high efficiency MERV 14 or 15 rated filters, e.g., a factor of 3.5x to 7x improvement ( $80 \%$

557 reduction). The larger improvement for apartments compared with single family residences is

558 due, in part, to four factors. First, $35 \%$ of the modeled single family residences do not have

559 forced air systems, and so improved filtration is possible only for $65 \%$ of these buildings.

560 Second, $65 \%$ of the apartment filters in the baseline scenario have low particle filtration

561 efficiency (MERV 5). Third, most smaller apartment buildings have lower infiltration rates.

562 Fourth, most larger apartment buildings rapidly recirculate indoor air through a filter contained

563 within the local heating/cooling system.

564 Figure 2 (bottom panel) shows the corresponding improvement for the three selected nonresidential building types. Overall, the results show patterns similar to those discussed for the

566 residential building types where the improvement for the Minimum MERV 7 and Minimum

567 MERV 11 scenarios are similar, a factor of $1.7 x$ to $2 x$ improvement ( $45 \%$ reduction) for retail

568 stores and schools and somewhat lower, a factor of $1.4 x$ to $1.7 x$ improvement ( $35 \%$

569 reduction), for office buildings. Again for most building types, notably greater improvement

570 occurs with the use of high efficiency MERV 14 or 15 rated filters, i.e., a factor of $3 x$ to $5 x$

571 improvement ( $70 \%$ reduction), and this effect is most noticeable for $1 \mu \mathrm{m}$ particles. 
medRxiv preprint doi: https://doi.org/10.1101/2020.05.14.20101311; this version posted May 20, 2020. The copyright holder for this preprint (which was not certified by peer review) is the author/funder, who has granted medRxiv a license to display the preprint in perpetuity.

It is made available under a CC-BY-ND 4.0 International license .

M Dillon and

R Sextro
Reducing Exposures to Airborne

Particles Through Improved Filtration
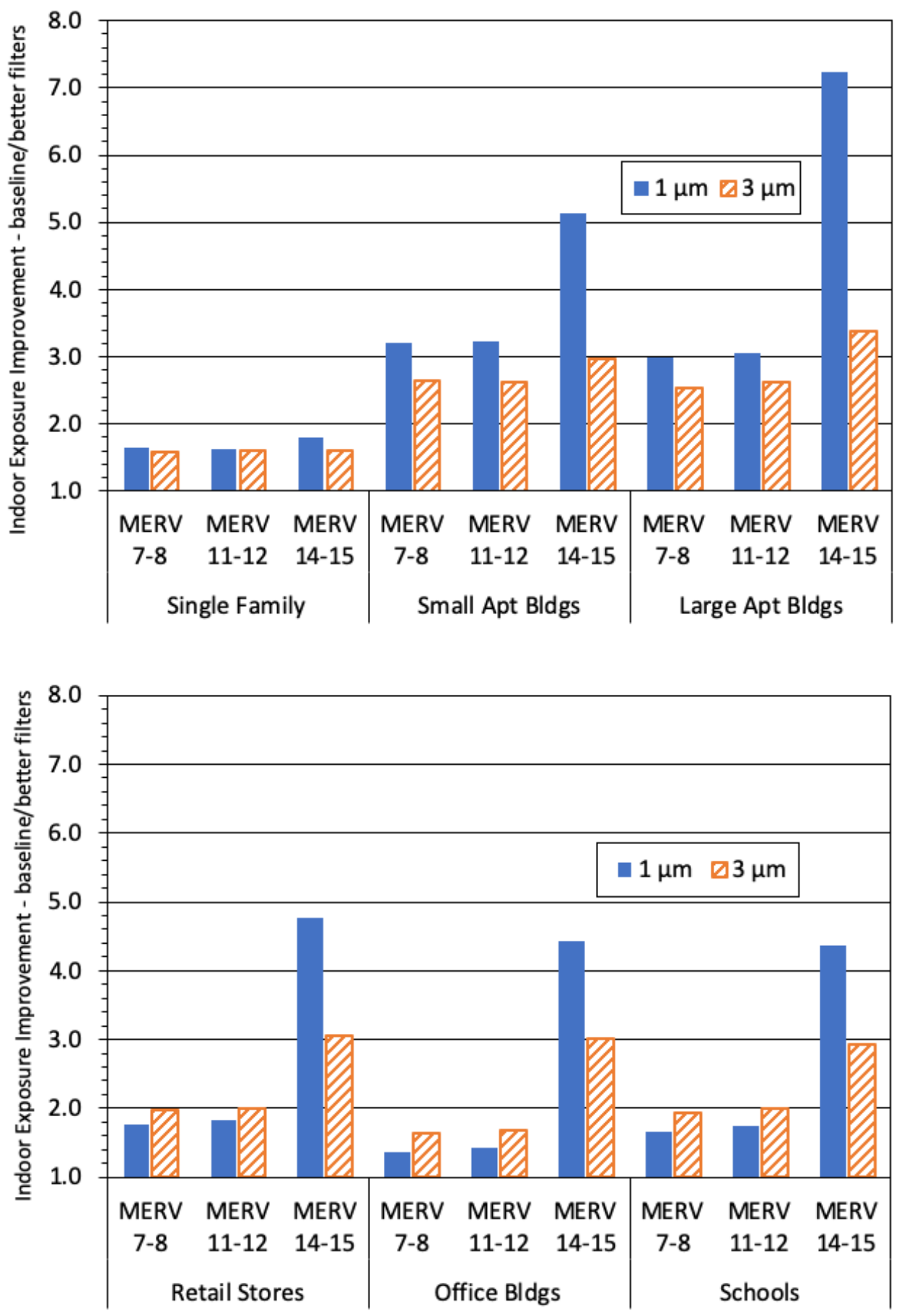

Figure 2. Improvement in the US Building Transmission Factor for selected residential (top panel) and non-residential (bottom panel) for selected building types; two aerosol sizes: $1 \mu \mathrm{m}$ (solid bar) and $3 \mu \mathrm{m}$ diameter (diagonal striped bar); and 3 minimum MERV ratings. The vertical axis is the ratio of the Building Transmission Factors for the baseline to the specified improved filtration scenario (a value of 1 indicates no improvement, larger numbers indicate greater improvement). 
medRxiv preprint doi: https://doi.org/10.1101/2020.05.14.20101311; this version posted May 20, 2020. The copyright holder for this preprint (which was not certified by peer review) is the author/funder, who has granted medRxiv a license to display the preprint in perpetuity.

It is made available under a CC-BY-ND 4.0 International license .

M Dillon and

R Sextro
Reducing Exposures to Airborne

Particles Through Improved Filtration

\subsection{Reducing Indoor Exposures to Indoor Airborne Particles (Indoor Normalized} TSIAC)

584 The baseline Indoor Normalized TSIAC results, shown in Figure 3, reflect our estimates of the 585 indoor exposure to airborne particles released indoors for six common US building types. There 586 is a wide range of Indoor Normalized TSIAC estimates, with the highest exposures (higher 587 values) present in single family homes and small apartment buildings and the lowest exposures 588 in office buildings. Exposures are lower for $3 \mu \mathrm{m}$ diameter aerosols, as compared to $1 \mu \mathrm{m}$ diameter aerosols. These results indicate that for particles released indoors, higher ventilation rates, combined with better particle filtration present in office and school buildings, provides lower exposures in non-residential buildings than is the case in residential buildings with lower

592 ventilation rates and reduced filtration capability.

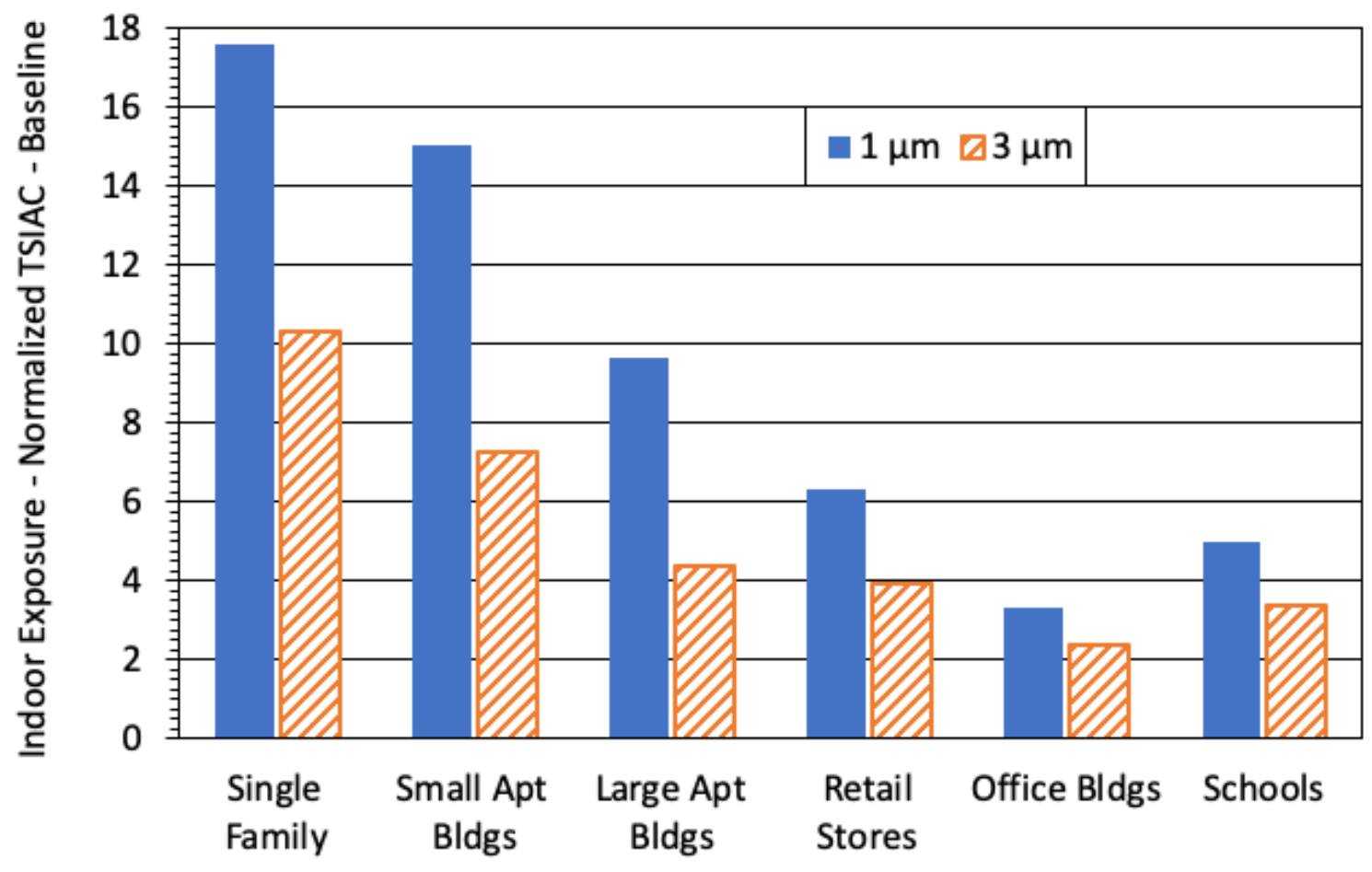

Figure 3. Baseline scenario results for the US Indoor Normalized Time and Space Integrated Air Concentration (Indoor Normalized TSIAC in $\mathrm{s} \mathrm{m}^{-1}$ ) - indoor exposures to indoor-origin airborne particles - for selected building types; and two aerosol sizes: $1 \mu \mathrm{m}$ (solid bar) and $3 \mu \mathrm{m}$ diameter (diagonal striped bar). Higher Indoor Normalized TSIAC values indicate more exposure. 
medRxiv preprint doi: https://doi.org/10.1101/2020.05.14.20101311; this version posted May 20, 2020. The copyright holder for this preprint (which was not certified by peer review) is the author/funder, who has granted medRxiv a license to display the preprint in perpetuity. It is made available under a CC-BY-ND 4.0 International license.

M Dillon and

R Sextro

Reducing Exposures to Airborne Particles Through Improved Filtration

600 Figure 4 presents the improvements associated with higher efficiency filtration using the ratio

601 of the Indoor Normalized TSIAC for the baseline scenario compared to the specified improved

602 filtration scenario for selected residential and non-residential buildings. In general, all building

603 types using a MERV 7 or higher rated filters have reductions in indoor exposures, however the

604 reduction is greater in residential buildings, with apartment buildings showing the largest

605 improvements.

606 Figure 4 (top panel) shows that for single family dwellings, the progression across the improved

607 filtration scenarios yields a factor of $1.5 x$ to $1.8 x$ improvement for the two particle sizes shown

608 ( $\sim 40 \%$ reduction in indoor exposures). For apartments, the magnitude of the improvement is

609 larger, a factor of $1.7 x$ to $3.4 x$ ( $~ 55 \%$ reduction) for the Minimum MERV 7 and MERV 11

610 scenarios. Again, greater improvement occurs with the use of high efficiency MERV 14 or 15

611 rated filters, e.g., a factor of $1.9 x$ to $5 x$ improvement (45\% to $80 \%$ reduction) for apartment

612 buildings. Again, the larger improvement for apartments compared with single family

613 residences is due, in part, to our assumption that many apartments currently have low

614 efficiency filters, and some, often smaller, US apartment buildings have lower infiltration rates

615 while other, often larger, apartments rapidly recirculate indoor air through a filter contained

616 within the local heating/cooling system.

617 Figure 4 (bottom panel) shows the corresponding improvement for the three selected non-

618 residential building types. Overall, the results show smaller improvements than those discussed

619 for the residential building types, a factor of $1.1 x$ to $1.3 x$ improvement ( $15 \%$ exposure

620 reduction) for the Minimum MERV 7 and Minimum MERV 11 scenarios. Greater improvement

621 occurs with the use of high efficiency MERV 14 or 15 rated filters, e.g., a factor of $1.1 x$ to $1.7 x$

622 improvement (10\% to $40 \%$ reduction). Exposures in non-residential buildings are less

623 responsive to improved filtration because the baseline filter quality distribution for non-

624 residential buildings is higher and because in most non-residential buildings the HVAC system is

625 already assumed to be operating $100 \%$ of the time. 
medRxiv preprint doi: https://doi.org/10.1101/2020.05.14.20101311; this version posted May 20, 2020. The copyright holder for this preprint (which was not certified by peer review) is the author/funder, who has granted medRxiv a license to display the preprint in perpetuity.

It is made available under a CC-BY-ND 4.0 International license .

M Dillon and

Reducing Exposures to Airborne

R Sextro

Particles Through Improved Filtration

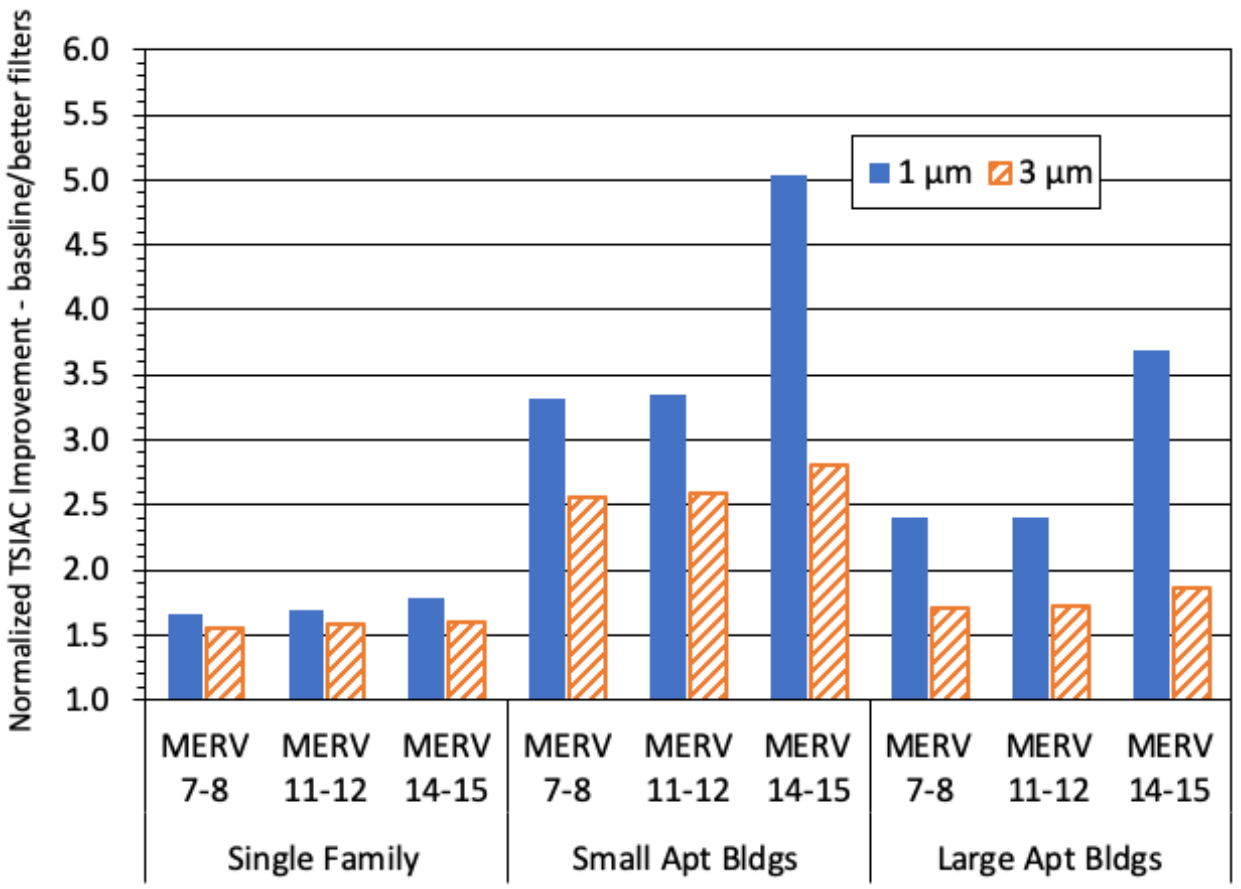

3.0

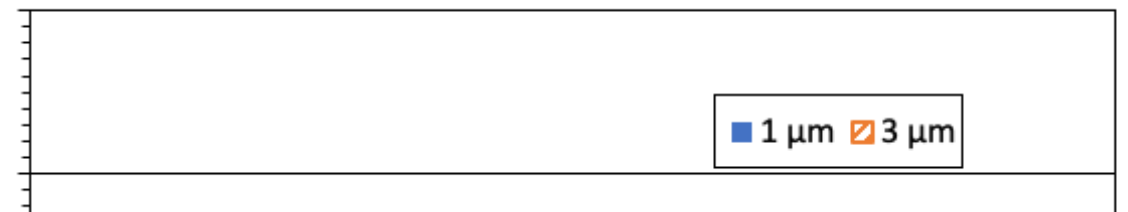

2.0

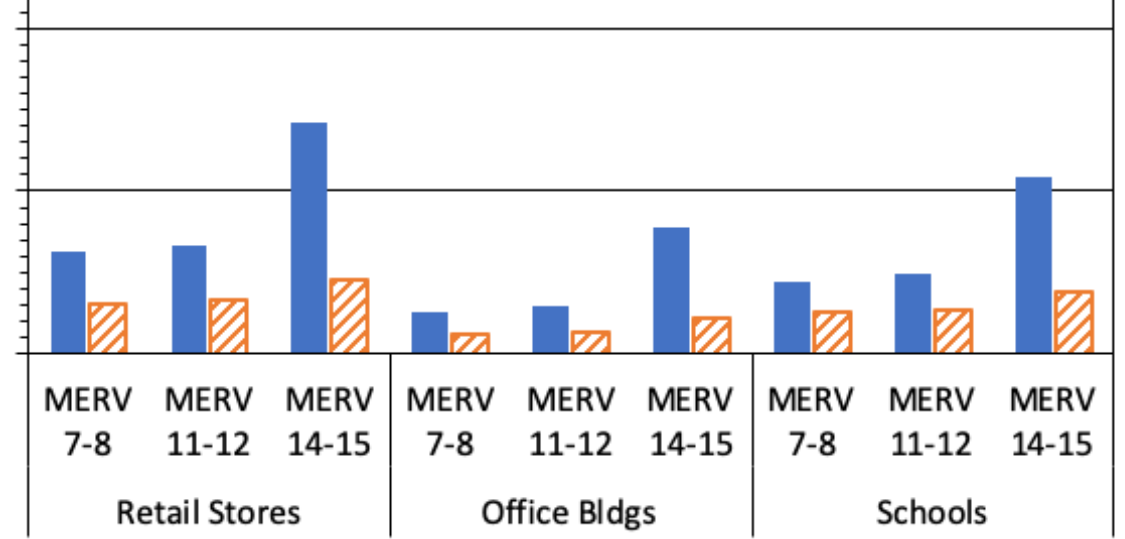

Figure 4. Improvement in the US Indoor Normalized TSIAC for selected residential (top panel) and non-residential (bottom panel) building types; two aerosol sizes: $1 \mu \mathrm{m}$ (solid bar) and $3 \mu \mathrm{m}$ diameter (diagonal striped bar); and 3 minimum MERV ratings. The vertical axis shows the ratio of the Indoor Normalized TSIAC for the baseline scenario to the specified improved filtration scenario (a value of 1 indicates no improvement, larger numbers indicate greater improvement). Note the factor of 2 difference in vertical scales between the top and bottom panels. 
medRxiv preprint doi: https://doi.org/10.1101/2020.05.14.20101311; this version posted May 20, 2020. The copyright holder for this preprint (which was not certified by peer review) is the author/funder, who has granted medRxiv a license to display the preprint in perpetuity. It is made available under a CC-BY-ND 4.0 International license .

M Dillon and

R Sextro

Reducing Exposures to Airborne Particles Through Improved Filtration

\subsection{Fraction of Indoor Airborne Particles Released to the Outdoors (Building Exit} Fraction)

639 Indoor air containing airborne particles exfiltrates and/or is mechanically exhausted from

640 buildings, providing a source of outdoor airborne particles. The baseline Building Exit Fraction

641 estimates, shown in Figure 5, reflect our estimates of the fraction of indoor airborne particles

642 that exit the selected US building types. There is a wide range of Building Exit Fraction

643 estimates, with the highest fractions (higher values) present in offices and school buildings and

644 the lowest in apartment buildings. Because the non-residential buildings have HVAC systems,

645 typically with an integral exhaust pathway, these buildings release more particles to outdoors

646 while for residential buildings, the exfiltration rate is lower and includes additional particle

647 losses as the exfiltrating air passes through cracks and other openings in the building shell.

648 Fewer $3 \mu \mathrm{m}$ diameter particles, as compared to $1 \mu \mathrm{m}$ diameter particles, are released to the

649 outdoors due to higher within-building losses for the $3 \mu \mathrm{m}$ diameter particles.

650 The indoor exposures to an indoor airborne particle (Indoor Normalized TSIAC) and the fraction

651 of indoor, airborne particles exiting the building are closely related, see Equation 7. As a result,

652 the Building Exit Fraction reductions for the improved filtration scenarios, Figure 6, relative to

653 the baseline scenario, are nearly identical to, but slightly lower than, the indoor exposure

654 improvements shown in the previous section, Figure 4. The difference is due to the particle

655 losses that occur during exfiltration.

656 
medRxiv preprint doi: https://doi.org/10.1101/2020.05.14.20101311; this version posted May 20, 2020. The copyright holder for this preprint (which was not certified by peer review) is the author/funder, who has granted medRxiv a license to display the preprint in perpetuity.

It is made available under a CC-BY-ND 4.0 International license .

M Dillon and

R Sextro
Reducing Exposures to Airborne Particles Through Improved Filtration

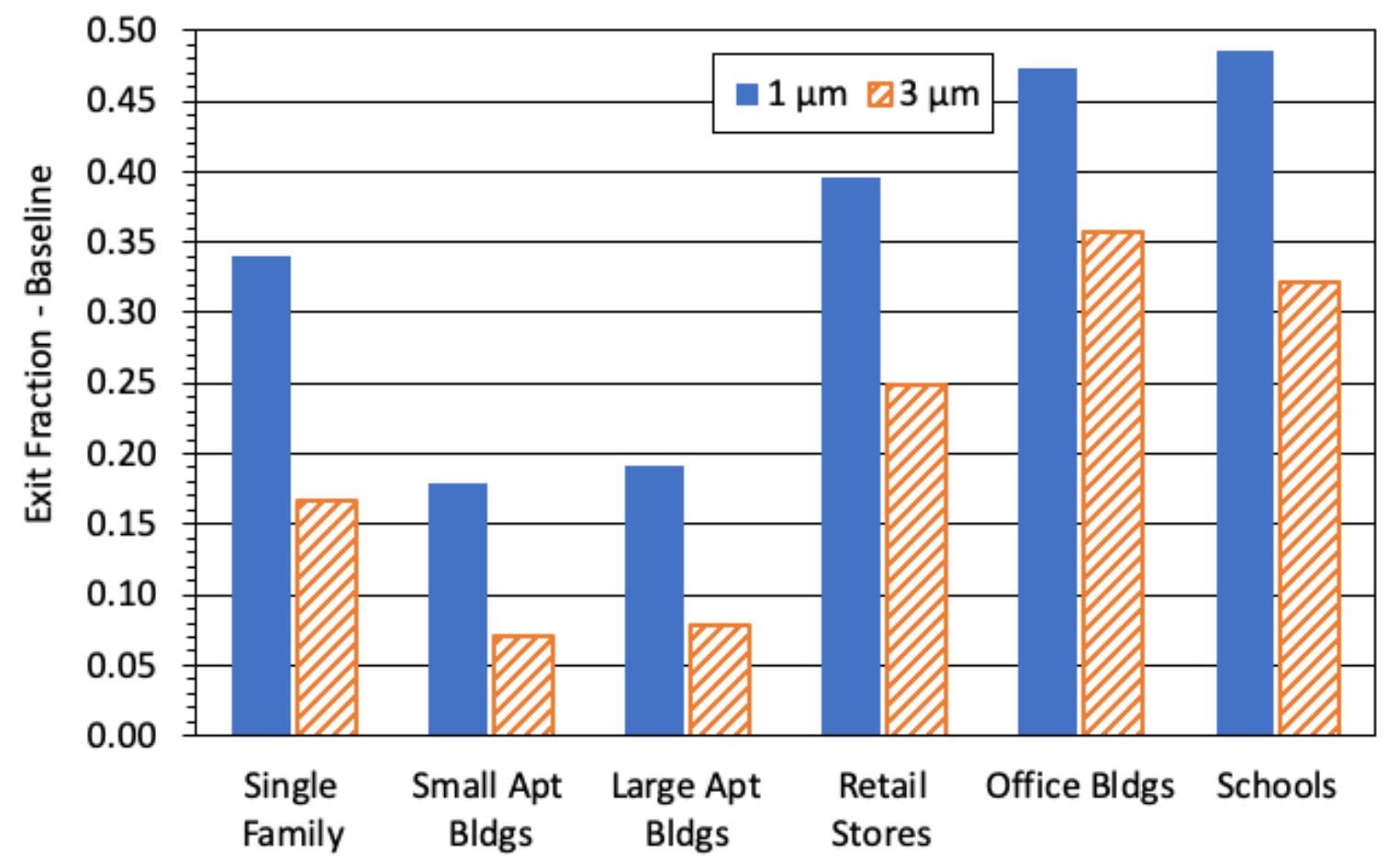

657
Figure 5. Baseline scenario results for the US Building Exit Fraction (dimensionless) - the fraction of indoor airborne particles that are released to the outdoor atmosphere - for selected building types; and two aerosol sizes: $1 \mu \mathrm{m}$ (solid bar) and $3 \mu \mathrm{m}$ diameter (diagonal striped bar). Higher Exit Fraction values correspond to more particles released to the outdoor atmosphere. 
medRxiv preprint doi: https://doi.org/10.1101/2020.05.14.20101311; this version posted May 20, 2020. The copyright holder for this preprint (which was not certified by peer review) is the author/funder, who has granted medRxiv a license to display the preprint in perpetuity.

It is made available under a CC-BY-ND 4.0 International license .

M Dillon and

R Sextro
Reducing Exposures to Airborne

Particles Through Improved Filtration

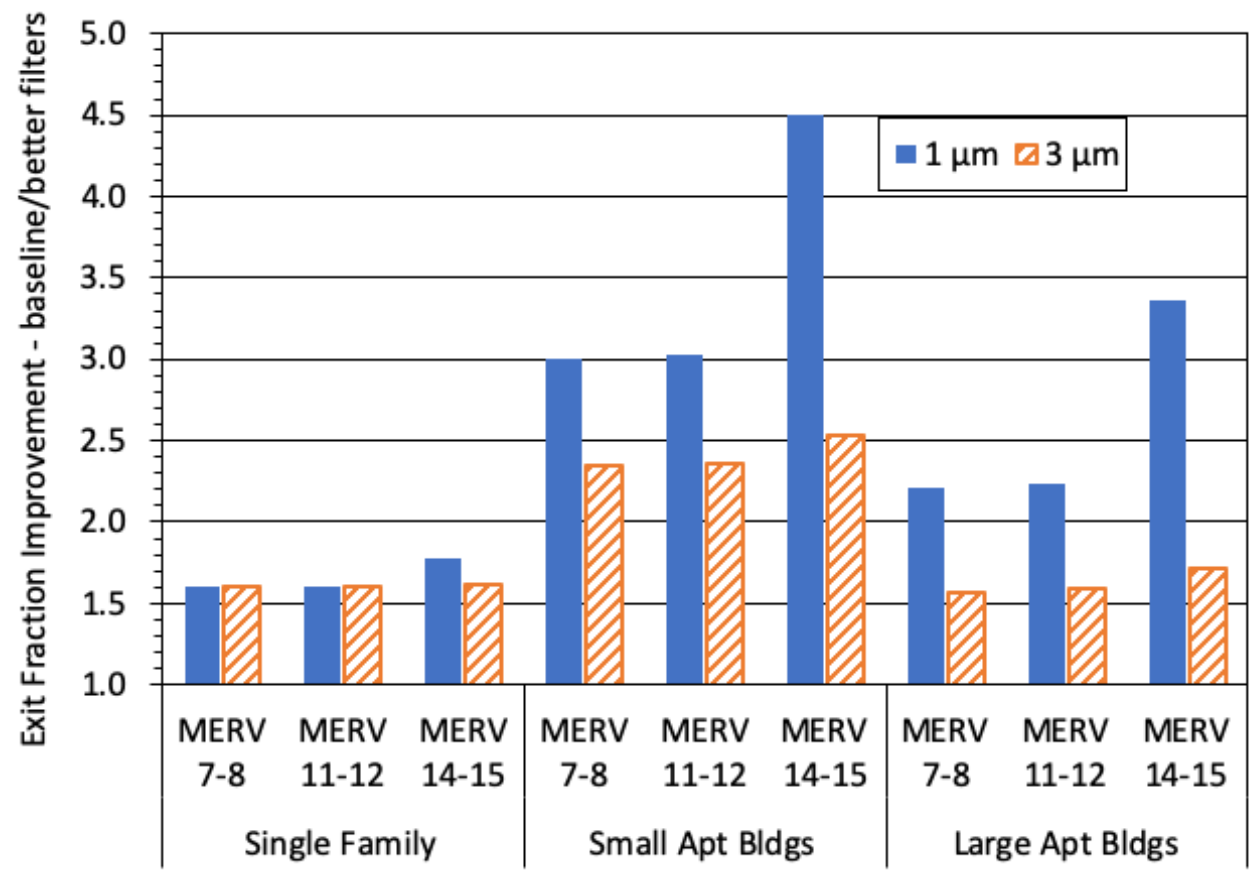

663

664

665

666

667

668

669

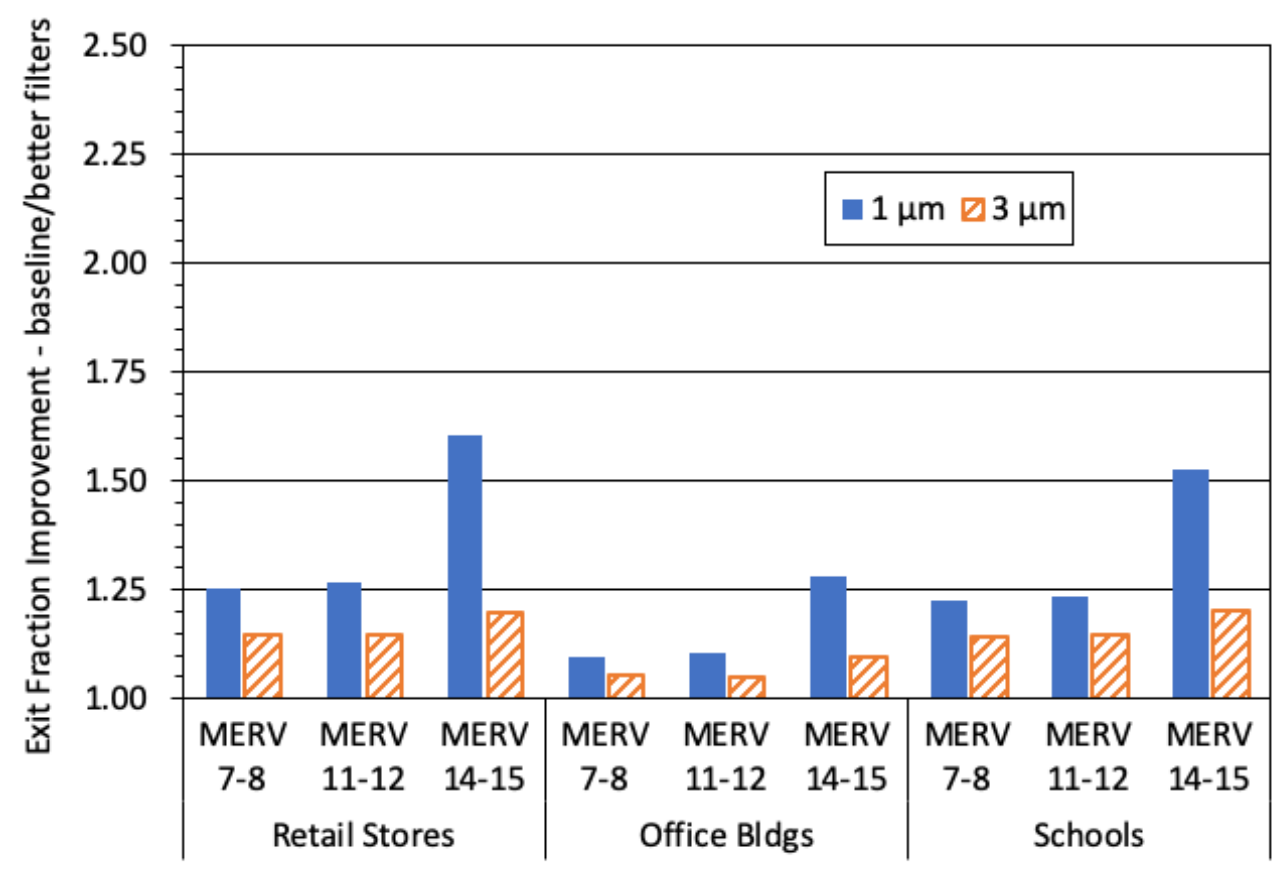

Figure 6. Improvement in the US Building Exit Fraction for selected residential (top panel) and non-residential (bottom panel) building types; two aerosol sizes: $1 \mu \mathrm{m}$ (solid bar) and $3 \mu \mathrm{m}$ diameter (diagonal striped bar); and 3 minimum MERV ratings. The vertical axis shows the ratio of Building Exit Fraction for the baseline scenario to the specified improved filtration scenario (a value of 1 indicates no improvement, larger numbers indicate greater improvement). Note the factor of 2 difference in vertical scales between the top and bottom panels. 
medRxiv preprint doi: https://doi.org/10.1101/2020.05.14.20101311; this version posted May 20, 2020. The copyright holder for this preprint (which was not certified by peer review) is the author/funder, who has granted medRxiv a license to display the preprint in perpetuity. It is made available under a CC-BY-ND 4.0 International license .

M Dillon and

R Sextro
Reducing Exposures to Airborne Particles Through Improved Filtration

671 Particles can exit a building, be transported downwind, and either expose outdoor individuals

672 or enter a second building to expose indoor, downwind individuals. Improving building air

673 filtration reduces indoor, downwind exposures through decreases in both the (a) fraction of

674 indoor airborne particles that exit the source building (Building Exit Fraction) and (b) the

675 fraction of outdoor airborne particles that enter the downwind building indoor air (the

676 downwind Building Transmission Factor), see Equation 9.

677 In general particles can be emitted from, and expose downwind individuals in, a wide variety of

678 different building types and a full Regional Shelter Analysis is required to model this common

679 general case where emissions and exposures occur across multiple building types, e.g., [6], [7].

680 While a full RSA is beyond the scope of the current study, estimates for overall air filtration

681 improvement benefits can be obtained for neighborhoods in which the population resides in a

682 homogenous housing stock.

683 Figure 7 presents the improvement associated with higher efficiency filtration using the ratio of

684 the Downwind Indoor Exposure for the baseline scenario compared to the specified improved

685 filtration scenario for selected residential buildings, see Equation 10. A value of 1 on the

686 vertical axis indicates no improvement over the baseline scenario. Larger numbers indicate

687 greater improvement.

688 In neighborhoods populated with single family homes, the Minimum MERV 7 and Minimum

689 MERV 11 scenarios provide a factor of 2.6x improvement for the two particle sizes shown $(60 \%$

690 reduction in downwind indoor exposures). The Minimum MERV 14 scenario providing slightly

691 more protection, a factor of $2.6 x$ to $3.2 x$ (65\% reduction). The improvement is notably greater

692 for neighborhoods populated with apartment buildings, with a $4 x$ to $10 x$ improvement (75\% to

$69390 \%$ reduction) for the Minimum MERV 7 and Minimum MERV 11 scenarios. The improvement

694 for the Minimum MERV 14 scenario ranges from 5.8x to $25 \times$ ( $85 \%$ to $96 \%$ reduction). In the

695 above results, the improvement for larger $3 \mu \mathrm{m}$ particles is less than that for $1 \mu \mathrm{m}$ particles, 696 especially so for the MERV 14 or 15 rated filters. 
medRxiv preprint doi: https://doi.org/10.1101/2020.05.14.20101311; this version posted May 20, 2020. The copyright holder for this preprint (which was not certified by peer review) is the author/funder, who has granted medRxiv a license to display the preprint in perpetuity.

It is made available under a CC-BY-ND 4.0 International license.

M Dillon and

R Sextro
Reducing Exposures to Airborne Particles Through Improved Filtration
698

699

700

701

702

703

704

705

706

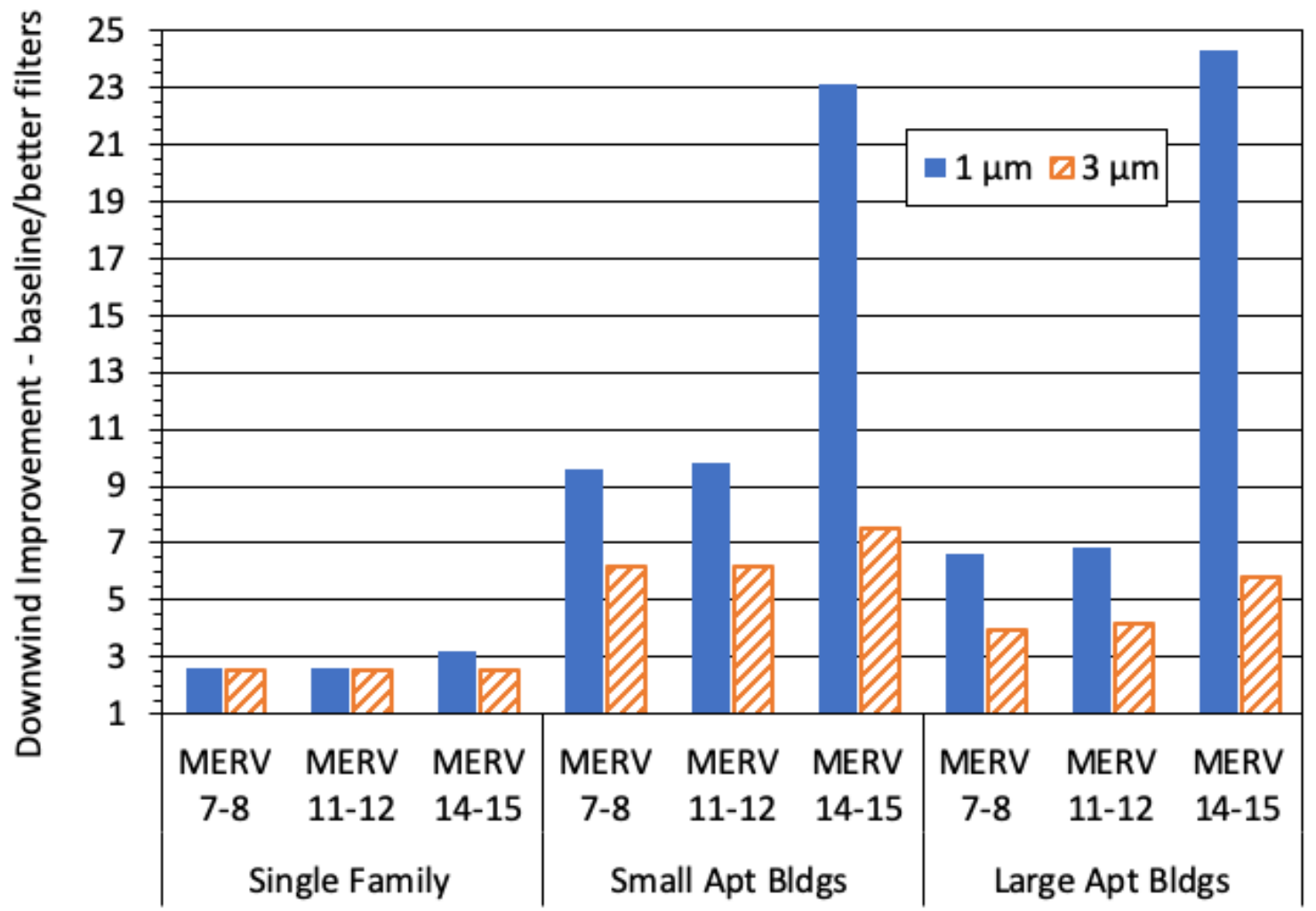

Figure 7. Improvement in the US Downwind Indoor Exposure for homogenous residential neighborhoods comprised of the selected building use types; two aerosol sizes: $1 \mu \mathrm{m}$ (solid bar) and $3 \mu \mathrm{m}$ diameter (diagonal striped bar); and 3 minimum MERV ratings. The vertical axis shows the ratio of the Downwind Indoor Exposure for the baseline scenario to the specified improved filtration scenario (a value of 1 indicates no improvement, larger numbers indicate greater improvement). 
medRxiv preprint doi: https://doi.org/10.1101/2020.05.14.20101311; this version posted May 20, 2020. The copyright holder for this preprint (which was not certified by peer review) is the author/funder, who has granted medRxiv a license to display the preprint in perpetuity. It is made available under a CC-BY-ND 4.0 International license .

M Dillon and

R Sextro
Reducing Exposures to Airborne Particles Through Improved Filtration

\section{Discussion and Conclusion}

708 This work broadly evaluates the extent to which improved airborne particle filtration in US 709 buildings may reduce airborne particle exposures. This work is based on an aggregation of 710 building types and a general set of parameters that describes both airflows into and out of 711 buildings as well as indoor particle behavior and removal processes. Our analysis suggests that, 712 for most building types studied, upgrades to the filters currently used in furnaces or HVAC 713 systems may reduce airborne particle exposures - although the degree of improvement varies

714 by filter efficiency, particle size, building type, and specific building. Our modeling indicates that 715 there is limited difference between scenarios which impose a minimum filter rating of MERV 7

716 vs. MERV 11, although both improved filtration scenarios are expected to reduce exposures 717 relative to the existing building stock. The largest reductions in airborne particulate exposures 718 are associated with the use of high filtration efficiency (MERV 14 or 15 rated) filters and, in 719 many cases, $1 \mu \mathrm{m}$ diameter particles, reflecting their typically larger improvements in filtration 720 efficiency for this particle size.

721 As a building use type, apartments benefit the most from improved, within-building filtration, in 722 part, due to our estimate that $65 \%$ of apartments currently have low efficiency (MERV 5 rated) 723 filters. In addition, and relative to other building use types examined, most smaller apartment 724 buildings have lower infiltration rates while most larger apartments rapidly recirculate indoor 725 air through a filter contained within the local heating/cooling system. Note that in order to 726 conform to the HAZUS building use types, we have modelled these two apartment categories 727 with a mix of heating/cooling system and air infiltration characteristics.

728 In contrast, the calculated improvement for single family homes is relatively modest due, in 729 part, to the estimated $35 \%$ of single family homes have heating systems, such as radiators and 730 in-wall heaters, that do not have filters and therefore cannot benefit from the use of improved 731 filters. This assumption limits the overall improvement, particularly for the Minimum MERV 14 732 scenario. For example, the Building Transmission Factor improves by a factor of $1.8 \mathrm{x}$ for the 733 Minimum MERV 14 scenario when considering the entire US building stock, but a factor of 5.8x 734 when considering the best protected buildings with filtered air handling systems (60\% of the 735 building stock $)^{1}$. This point is also pertinent when comparing our modeling results with other 736 studies results as discussed below.

${ }^{1}$ The mean of the "Median," "2 ${ }^{\text {nd }}$ Lowest," and "Lowest" distribution categories is 0.06 for the Minimum MERV 14 scenario; RES1 building use type; 1 um diameter particles; and $0 \mathrm{hr}^{-1}$ airborne loss rate. For context, the mean of all distribution categories is 0.19 . The corresponding mean for the baseline scenario is 0.35. See Supplemental Material A: Detailed Results for more details. 
medRxiv preprint doi: https://doi.org/10.1101/2020.05.14.20101311; this version posted May 20, 2020. The copyright holder for this preprint (which was not certified by peer review) is the author/funder, who has granted medRxiv a license to display the preprint in perpetuity. It is made available under a CC-BY-ND 4.0 International license .

M Dillon and

R Sextro
Reducing Exposures to Airborne Particles Through Improved Filtration

\subsection{Comparison to Prior Work}

739 While there are ample data on the filtration efficiency of various filters and filter types, there

740 are fewer studies that have experimentally assessed the performance of filters in whole

741 buildings. Most are research studies conducted in one or a small number of buildings. Hence

742 the data available for comparison with our modeling results are not broadly representative of

743 the building types studied here. We summarize below a selected (non-comprehensive) set of

744 results from such studies to provide context for our current work. We compile the results from

745 these studies - along with our comparative modeling results - in Table 11. The pertinent details

746 of the previous studies are discussed below.

747 Howard-Reed et al. [19] performed one of the first experimental assessments of the effect of

748 filter efficiency on indoor particle concentrations in a normally occupied home. Howard-Reed et

749 al. compared the use of a 'typical' panel furnace filter (PFF) with that of an in-duct electrostatic

750 precipitator (ESP). Although the authors did not provide filter ratings for these devices, the

751 filtration efficiencies measured in their tests are approximately consistent with the MERV 5 and

752 MERV 12 filtration efficiencies shown in Table 10 above for the PFF and ESP, respectively. The

753 furnace fan was operated only when particle concentration measurements were conducted,

754 and then only following the times when particles were generated indoors. Similar tests were

755 conducted in an unoccupied test house that had a lower indoor/outdoor air change rate than

756 the occupied dwelling. Using the measured filtration rate and particle loss rate data, the

757 authors estimated the effect of filtration on the ratios of the concentrations of indoor particles

758 of outdoor origin to outdoor particle concentrations. The estimated indoor/outdoor ratios for

759 the PFF and ESP cases are given in Table $\mathbf{1 1}$ and are consistent with the range of Building

760 Transmission Factors that we predict for single family homes. ${ }^{2}$ The Howard-Reed et al. data

761 show a definite improvement that is somewhat larger than the improvement predicted by our

762 modeling work for the US single family home building stock. However, the reported

763 improvement with the better (ESP) filter is similar to our prediction that considers only the

764 portion of the single family building stock that has filtration-capable heating systems.

\footnotetext{
${ }^{2}$ Data from this study was used in developing the indoor deposition rate values used in our analysis.
} 
medRxiv preprint doi: https://doi.org/10.1101/2020.05.14.20101311; this version posted May 20, 2020. The copyright holder for this preprint (which was not certified by peer review) is the author/funder, who has granted medRxiv a license to display the preprint in perpetuity.

It is made available under a CC-BY-ND 4.0 International license.

M Dillon and

Reducing Exposures to Airborne

R Sextro

Particles Through Improved Filtration

Table 11. Summary of Building Transmission Factors for current and prior analyses.

\begin{tabular}{|c|c|c|c|c|c|}
\hline Building & $\begin{array}{c}\text { Particle } \\
\text { Size } \\
(\mu \mathrm{m})\end{array}$ & $\begin{array}{c}\text { Baseline } \\
\text { Transmission } \\
\text { Factor } \\
\text { (no units) }\end{array}$ & $\begin{array}{c}\text { Improved } \\
\text { Filtration } \\
\text { Transmission } \\
\text { Factor } \\
\text { (no units) } \\
\end{array}$ & $\begin{array}{c}\text { Improvement } \\
\text { Ratio } \\
\text { (baseline / } \\
\text { improved) }\end{array}$ & Study \\
\hline \multicolumn{6}{|c|}{ Detached Single Family Homes } \\
\hline & 1 to 2.5 & 0.4 & 0.2 & 2 & \multirow{2}{*}{$\begin{array}{c}\text { Howard-Reed } \\
\text { [19] }\end{array}$} \\
\hline $\begin{array}{l}\text { unoccupied } \\
\text { test house }\end{array}$ & 1 to 2.5 & 0.12 & 0.05 & 2.4 & \\
\hline $\begin{array}{l}\text { unoccupied } \\
\text { test house }\end{array}$ & $\mathrm{PM}_{2.5}$ & 0.25 & 0.07 & 3.6 & Singer [20] \\
\hline $\begin{array}{c}\text { Modeled } \\
\text { homes }\end{array}$ & $\mathrm{PM}_{2.5}$ & $0.35(0.13-0.94)^{(a)}$ & $0.10(0.02-0.80)^{(a)}$ & 3.5 & Macintosh [21] \\
\hline \multirow{2}{*}{ RES1 } & 1 & $0.35(0.09-0.67)^{(b)}$ & $0.19(0.03-0.57)^{(b)}$ & 1.8 & \multirow{2}{*}{ present study } \\
\hline & 3 & $0.16(0.04-0.38)^{(b)}$ & $0.10(0.02-0.30)^{(b)}$ & 1.6 & \\
\hline \multicolumn{6}{|c|}{ Office } \\
\hline \multirow{2}{*}{$\begin{array}{l}\text { occupied } \\
\text { multi-story } \\
\text { office }\end{array}$} & 1 to 2 & 0.22 & 0.1 & 2.2 & \multirow{2}{*}{ Fisk [22] } \\
\hline & $>2$ & $0.42^{\text {(c) }}$ & $0.4^{(c)}$ & 1.2 & \\
\hline \multirow{2}{*}{ COM4 } & 1 & $0.25(0.04-0.63)^{(b)}$ & $0.06(0.01-0.12)^{(b)}$ & 4.4 & \multirow{2}{*}{ present study } \\
\hline & 3 & $0.10(0.01-0.29)^{(b)}$ & $0.03(0.01-0.08)^{(b)}$ & 3.0 & \\
\hline \multicolumn{6}{|c|}{ School } \\
\hline $\begin{array}{l}\text { unoccupied } \\
\text { classroom }\end{array}$ & $\mathrm{PM}_{2.5}$ & 0.73 & 0.42 & 1.7 & Van der Zee [23] \\
\hline $\begin{array}{l}\text { occupied } \\
\text { classroom }\end{array}$ & $\mathrm{PM}_{2.5}$ & 0.63 & 0.12 & 5.3 & Polidori [24] \\
\hline \multirow{2}{*}{ EDU1 } & 1 & $0.34(0.08-0.70)^{(b)}$ & $0.08(0.03-0.15)^{(b)}$ & 4.4 & present study \\
\hline & 3 & $0.14(0.03-0.33)^{(b)}$ & $0.05(0.02-0.10)^{(b)}$ & 2.9 & present study \\
\hline
\end{tabular}

(a) median and 5 to $95 \%$ range from the CONTAM model results

(b) In the present work, model outputs are reported in five equally sized bins with the average value reported for each bin. The results provided are the average of all five bins and the range in the individual bin averages for the baseline and Minimum MERV14 scenarios.

(c) Study authors suspected the presence of indoor particle sources, particularly for $>2 \mu \mathrm{m}$ diameter particles, resulting in higher indoor/outdoor ratio than would otherwise be expected based on the efficiencies of the baseline and upgraded filters. 
medRxiv preprint doi: https://doi.org/10.1101/2020.05.14.20101311; this version posted May 20, 2020. The copyright holder for this preprint (which was not certified by peer review) is the author/funder, who has granted medRxiv a license to display the preprint in perpetuity. It is made available under a CC-BY-ND 4.0 International license .

M Dillon and

R Sextro
Reducing Exposures to Airborne Particles Through Improved Filtration

775 Singer et al. [20] conducted an extensive set of ventilation and filtration system experiments in

776 an unoccupied single family home. The reference furnace fan system contained a MERV 4 filter

777 placed in the return duct to the air handler. The comparison system closest to the one modeled

778 in the present work upgraded the MERV 4 filter to a higher particle removal efficiency (MERV

779 13) filter (system $E$ in their work). The ratios of indoor to outdoor $\mathrm{PM}_{2.5}$ particle concentrations

780 - based on the 24-hour average of several days of continuous data - are shown in Table 11. The 781 observed indoor/outdoor $\mathrm{PM}_{2.5}$ concentration ratios are within the range of single family home

782 Building Transmission Fractions predicted by the present study, which includes some systems

783 with no filters. The observed improvement factor is larger than our modeling estimates.

784 Macintosh et al. [21] modeled the effectiveness of forced-air furnace-system air cleaning on 785 reducing indoor concentrations of outdoor $\mathrm{PM}_{2.5}$. The analysis was based on the use of actual

786 24-hour average outdoor $\mathrm{PM}_{2.5}$ measurements during 2005 for three metropolitan areas in the 787 state of Ohio, a set of single family prototypical dwelling designs, the CONTAM multizone air 788 flow model, and two filtration assumptions. The first filtration assumption was a conventional 789 furnace-system filter with an assumed $\mathrm{PM}_{2.5}$ removal efficiency of $\sim 14 \%$ (roughly equivalent to 790 the MERV 5 filters used in the present analysis) and the second was an electrostatic precipitator 791 (ESP) with an assumed filtration efficiency of 90\% (an efficiency similar to the MERV 11-12

792 filtration category used here). The two systems were assumed to have different operating duty 793 cycles - in the first, the forced air system operated only in response to heating/cooling demand 794 while for the second, the system was assumed to have a variable speed fan that operated at 795 high speed during heating/cooling demand and at half-speed during all other times. The

796 simulation outputs, when combined across all prototypical buildings and the outdoor 797 concentrations data from the three cities, yield the indoor/outdoor ratios shown in Table 11.

798 The corresponding improvement factor is again similar to, but greater than, our modeling 799 results.

800 Comparable tests in non-residential buildings are fewer. Fisk et al. [22] measured the ratio of 801 indoor to outdoor particle concentrations in a large office building under two filtration 802 scenarios: (a) the existing filter that had an estimated MERV rating of 5 to 6 and (b) a high 803 efficiency filtration system corresponding to a MERV 15 filtration efficiency. The observed 804 indoor/outdoor ratios for the two particle size categories are shown in Table $\mathbf{1 1}$ along with our 805 performance predictions for office buildings. The overall filtration efficiency and the 806 improvement ratio observed by Fisk et al. are more modest than expected and are lower than 807 our predictions. As discussed in [22], the experiments were conducted on two floors of the 808 multistory building while both floors were occupied (160 to 280 people per floor). It is clear, 809 especially from the data for particles larger than $2 \mu \mathrm{m}$ in diameter, that there were important 810 indoor sources for these particles that complicated the evaluation of the filtration performance 
medRxiv preprint doi: https://doi.org/10.1101/2020.05.14.20101311; this version posted May 20, 2020. The copyright holder for this preprint (which was not certified by peer review) is the author/funder, who has granted medRxiv a license to display the preprint in perpetuity. It is made available under a CC-BY-ND 4.0 International license.

M Dillon and Reducing Exposures to Airborne R Sextro Particles Through Improved Filtration

811 (and improvement). As this building was selected to have non-smoking occupants, a likely,

812 though unverified, source of larger particles was resuspension.

813 Improvements to particle filtration in schools have also been investigated. Van der Zee et al.

814 [23] evaluated improving classroom filtration to a MERV 14 rated filter (from a baseline MERV

81510 rated filter of dubious maintenance history) - along with other ventilation system

816 performance changes. These changes resulted in a modest improvement in the indoor/outdoor

$817 \mathrm{PM}_{2.5}$ ratio based on the non-teaching hour data (indoor particle concentrations during the

818 teaching hours are strongly influenced by indoor particle sources), see Table 11. Polidori et al.

819 [24] measured the airborne particle removal effectiveness of MERV 16 filters installed in HVAC

820 systems serving classrooms in three schools - replacing baseline MERV 7 filters in these

821 schools. $^{3}$ The Polidori et al. study data collection was done entirely during school hours, though

822 there were time periods during the day, such as outdoor recess and lunchtime, when the

823 students were not in the classrooms. However, data during the empty classroom periods were

824 not explicitly analyzed separately. The Polidori et al. measured ratio of real-time, concurrent

825 indoor to outdoor $\mathrm{PM}_{2.5}$ concentrations demonstrated notably larger improvement with the

826 increased filtration efficiency than the prior Van der Zee et al. study, see Table 11.

827 Our modeling predictions are broadly consistent with these school studies. Most of the

828 observed Building Transmission Factor values are consistent with the upper bound of our

829 modeling results. Also if the van der Zee et al. baseline filtration is MERV 10 (as appears to be

830 the case) or even higher (if the existing, baseline filters were heavily loaded), then the observed

831 improvement factor of $1.7 x$ is similar to our calculated improvement factor of $2.5 x$ and $1.5 x$ for

8321 and $3 \mu \mathrm{m}$ diameter particles, respectively, using the Minimum MERV 11 scenario as the

833 baseline filter. As seen in the analysis of single family homes, the improvement factor measured

834 by Polidori et al. is similar to, but greater than, our modeling results.

\footnotetext{
${ }^{3}$ Data from this study was one of the data sources used in developing the airflow parameter values used in our analysis.
} 
medRxiv preprint doi: https://doi.org/10.1101/2020.05.14.20101311; this version posted May 20, 2020. The copyright holder for this preprint (which was not certified by peer review) is the author/funder, who has granted medRxiv a license to display the preprint in perpetuity. It is made available under a CC-BY-ND 4.0 International license .

M Dillon and

R Sextro
Reducing Exposures to Airborne Particles Through Improved Filtration

\subsection{Other Considerations}

While our US building type filtration modeling results are broadly consistent with those of previous, individual building studies, the details of a particular building and/or the heating and cooling system will strongly influence the overall improvement seen for any given building. A recent analysis of residential filter effectiveness found that the "context" in which the filtration occurs matters. Context in this sense refers to a variety of factors that affect indoor air quality, including the overall building indoor/outdoor air change rate. Essentially this approach argues that filtration effectiveness is a system parameter that depends upon the overall operating conditions of the house [25]. For example, in some systems/houses they found greater filtration effectiveness in increasing system run time (furnace fan duty cycle) rather than simply upgrading the filter efficiency. This finding is consistent with the order of magnitude variability predicted by our study for residences where we explicitly account for variability in air change rates, indoor deposition losses, and, in the baseline scenario, furnace fan duty cycles. We note that the improved filtration scenarios examined in our analysis assume a $100 \%$ system run time (i.e., the furnace fan is always on).

The California Air Resources Board and US Environmental Protection Agency provide additional guidance on practical measures to improve residential air filtration, including the use of portable air filtration devices in buildings without forced air systems [26]-[28]. While a complete analysis of portable air filtration devices is beyond the scope of this study, we briefly discuss the use of portable air cleaners with regards to typical US residences. ${ }^{4}$ For discussion purposes, we use the Clean Air Delivery Rate (CADR) metric, which is the production rate of clean air $\left(\mathrm{ft}^{3} \mathrm{~min}^{-1}\right.$ ) by a filtration system [30], [31]. ${ }^{5}$ For typical residences with a MERV 7 rated filter and an always-on ( $100 \%$ duty cycle) furnace fan, the single family home and apartment furnace "CADR" values are $\sim 1200$ and $\sim 440 \mathrm{ft}^{3} \mathrm{~min}^{-1}$, respectively. ${ }^{6}$ In comparison, portable air cleaners intended for room cleaning have individual unit CADR ratings in the range of $\sim 250$ to $400 \mathrm{ft}^{3} \mathrm{~min}^{-1}$. Thus to achieve a comparable reduction in indoor airborne particle exposure, the use of one or more portable air cleaners would be needed. We note that individual portable air cleaners are typically intended to clean air in only one or two rooms, in contrast most furnacebased systems that are designed to distribute filtered air within the living space. Portable air cleaners can be useful alternatives for dwellings where forced air systems aren't present, such

\footnotetext{
${ }^{4}$ Per [29], the typical US detached single family home and apartment has 2,200 and $840 \mathrm{ft}^{2}$ of heated floor area, respectively. Assuming an $8 \mathrm{ft}$ room height, the corresponding building volumes are 18,000 and $6,700 \mathrm{ft}^{3}$, respectively.

${ }^{5}$ We note that the formal AHAM CADR testing standard does not cover the whole-building filtration systems but the term can be applied to any forced air filtration system.

${ }^{6} \mathrm{CADR}=F_{\text {filter }} \times F_{r \text {,fan }} \times r_{\text {fan }} \times$ Building Volume. Per Table 3, the furnace fan flow rate is $5.7 \mathrm{~h}^{-1}$ and per Table 10, the median MERV 7 rated filter efficiency for $1 \mu \mathrm{m}$ particles is 0.69 .
} 
medRxiv preprint doi: https://doi.org/10.1101/2020.05.14.20101311; this version posted May 20, 2020. The copyright holder for this preprint (which was not certified by peer review) is the author/funder, who has granted medRxiv a license to display the preprint in perpetuity. It is made available under a CC-BY-ND 4.0 International license .

M Dillon and

R Sextro
Reducing Exposures to Airborne Particles Through Improved Filtration

866 as single family homes that lack forced air furnace systems or as a supplement to existing

867 whole-house filtration, e.g., [32]. For context, the Association of Home Appliance

868 Manufacturers (AHAM) recommends that "appropriately sized" portable air cleaners are 2/3 of 869 the floor area of the space being cleaned [33], which corresponds to an additional loss term of $8705 \mathrm{~h}^{-1}\left(\lambda_{\text {portable air filter }}=\right.$ CADR / Building Volume $)$.

871 Another important simplifying assumption in our analysis is the use of a single, albeit well872 mixed, box with closed windows and doors as the basis for modeling indoor particulate 873 exposures. In the context of complex, multizone buildings; many larger buildings contain 874 multiple HVAC systems which may vary in their filtration capabilities. In some cases, there is 875 little air (and thus airborne particles) exchanged between zones and so the overall building can 876 be modeled as the combination of independent, well-mixed zones as is done in this study with 877 institutional housing (RES4, RES5, and RES6 building types). However, in other cases the effects 878 of improved filtration may be physically localized in ways not captured in our estimates. As one 879 example, we assume that HVAC filters in hospital air handling systems are uniformly rated 880 MERV 14 or 15 and so, for this building type, no improvement is predicted (i.e., all hospitals 881 already have the highest rated filters considered in our analysis). Future work could investigate 882 the degree to which all zones have the same filtration capabilities and therefore if the air 883 quality in some building zones could benefit from the use of higher rated filters.

884 Furthermore, the Indoor Normalized TSIAC results provided here are intended for use within a 885 single-well mixed zone. As such they are not appropriate to assess within building, but cross 886 zone contamination spread. For example, an apartment building may have many apartments, 887 each with a separate HVAC system (zone). The Indoor Normalized TSIAC results presented here 888 could be used to assess the degree to which particles released in one apartment exposes

890 here, does not inform the degree to which individuals in a neighboring apartment are exposed.

891 Finally the parameters used in this study are representative descriptions of the factors affecting 892 air flow and particle behavior in US buildings. In some cases, the parameter values chosen were 893 based on limited information available in the literature and thus are thus based on the best 894 existing data combined with our best engineering judgement. Dillon et al. [7] provides further 895 discussion and suggestions for future research to improve these parameter values. We note 896 that regardless of these uncertainties, our results broadly suggest that improving air filtration in 897 buildings can reduce indoor airborne particle exposures across a wide range of building types. 898 Further, the analysis methodology developed here could be applied to more detailed building 899 models, including studies of specific buildings, where specific parameter values could be better 900 characterized. 
medRxiv preprint doi: https://doi.org/10.1101/2020.05.14.20101311; this version posted May 20, 2020. The copyright holder for this preprint (which was not certified by peer review) is the author/funder, who has granted medRxiv a license to display the preprint in perpetuity. It is made available under a CC-BY-ND 4.0 International license.

M Dillon and

R Sextro
Reducing Exposures to Airborne Particles Through Improved Filtration

\section{Acknowledgements}

904 The authors also express their gratitude to their family for their support and enduring patience. The authors also thank Charles Dillon for his assistance during the development of this manuscript. Furthermore, the authors acknowledge the helpful reviews by Tarabay Antoun, Ron Baskett, Brooke Buddemeier, John Nasstrom, and Brenda Pobanz of the Lawrence Livermore National Laboratory; Dev Jani of the US Department of Homeland Security, Countering Weapons of Mass Destruction Office; Lance Wallace of Wallace Research; Woody Delp of the Lawrence Berkeley National Laboratory; and Thomas Phillips of Healthy Building

911 Research.

This document was prepared as an account of work sponsored by an agency of the United States government. Neither the United States government nor Lawrence Livermore National Security, LLC, nor any of their employees makes any warranty, expressed or implied, or assumes any legal liability or responsibility for the accuracy, completeness, or usefulness of any information, apparatus, product, or process disclosed, or represents that its use would not infringe privately owned rights. Reference herein to any specific commercial product, process, or service by trade name, trademark, manufacturer, or otherwise does not necessarily constitute or imply its endorsement, recommendation, or favoring by the United States government or Lawrence Livermore National Security, LLC. The views and opinions of authors expressed herein do not necessarily state or reflect those of the United States government or Lawrence Livermore National Security, LLC, and shall not be used for advertising or product endorsement purposes.

Lawrence Livermore National Laboratory is operated by Lawrence Livermore National Security, 
medRxiv preprint doi: https://doi.org/10.1101/2020.05.14.20101311; this version posted May 20, 2020. The copyright holder for this preprint (which was not certified by peer review) is the author/funder, who has granted medRxiv a license to display the preprint in perpetuity. It is made available under a CC-BY-ND 4.0 International license .

M Dillon and

R Sextro
Reducing Exposures to Airborne Particles Through Improved Filtration

\section{Attestations}

\section{Ethics statement}

No humans or animals were used this in work

\section{Data accessibility} No primary data were used in this analysis. The referenced supplemental material has been provided.

\section{Competing interests}

The authors have no competing interests for the material provided in this manuscript beyond being and/or previously employed at our respective organizations.

\section{Author's contributions}

Michael Dillon (MBD) was responsible for the study concept and design, model development and analysis and manuscript drafting and revision.

Richard Sextro (RGS) provided quality control review of building metric equations, developed both the graphs and comparison against prior results, and significantly contributed to the overall manuscript drafting and revision.

Charles Dillon (CFD) provided editorial review and feedback during the manuscript revision process.

All authors give approval for release.

\section{Funding statement}

MBD was supported, in part, by the US Department of Homeland Security for early related efforts.

RGS was self-supported.

CFD was self-supported. 
medRxiv preprint doi: https://doi.org/10.1101/2020.05.14.20101311; this version posted May 20, 2020. The copyright holder for this preprint (which was not certified by peer review) is the author/funder, who has granted medRxiv a license to display the preprint in perpetuity. It is made available under a CC-BY-ND 4.0 International license .

M Dillon and

R Sextro
Reducing Exposures to Airborne Particles Through Improved Filtration
965

966

967

968

969

970

971

972

973

974

975

976

977

978

979

980

981

982

983

984

985

986

987

988

989

990

991

992

993

994

995

996

\section{References}

[1] S. S. Nadadur and J. W. Hollingsworth, Air Pollution and Health Effects. London: Springer London, 2015.

[2] R. D. Brook et al., "Particulate Matter Air Pollution and Cardiovascular Disease: An Update to the Scientific Statement From the American Heart Association," Circulation, vol. 121, no. 21, pp. 2331-2378, Jun. 2010, doi: 10.1161/CIR.0b013e3181dbece1.

[3] C. A. Pope and D. W. Dockery, "Health effects of fine particulate air pollution: lines that connect," J Air Waste Manag Assoc, vol. 56, no. 6, pp. 709-742, Jun. 2006, doi: 10.1080/10473289.2006.10464485.

[4] J. D. Kaufman et al., "Advances in Understanding Air Pollution and CVD," gh, vol. 11, no. 3, p. 343, Sep. 2016, doi: 10.1016/j.gheart.2016.07.004.

[5] "Wildfire Smoke: A Guide for Public Health Officials," US Environmental Protection Agency, EPA-452/R-19-901, Aug. 2019.

[6] M. B. Dillon and C. F. Dillon, "Regional Shelter Analysis - Inhalation Exposure Methodology," Lawrence Livermore National Laboratory, Livermore, CA, LLNL-TR-786042, Aug. 2019.

[7] M. B. Dillon, R. G. Sextro, and W. W. Delp, "Regional Shelter Analysis - Inhalation Exposure Application (Particles)," Lawrence Livermore National Laboratory, Livermore, CA, LLNL-TR786237, Aug. 2019.

[8] C. B. Keil, "A Tiered Approach to Deterministic Models for Indoor Air Exposures," Applied Occupational and Environmental Hygiene, vol. 15, no. 1, pp. 145-151, Jan. 2000, doi: 10.1080/104732200301962.

[9] T. L. Thatcher, M. M. Lunden, K. L. Revzan, R. G. Sextro, and N. J. Brown, “A Concentration Rebound Method for Measuring Particle Penetration and Deposition in the Indoor Environment," Aerosol Science and Technology, vol. 37, no. 11, pp. 847-864, Nov. 2003, doi: 10.1080/02786820300940.

[10] F. H. Shair and K. L. Heitner, "Theoretical model for relating indoor pollutant concentrations to those outside," Environmental Science \& Technology, vol. 8, no. 5, pp. 444-451, May 1974, doi: 10.1021/es60090a006.

[11] J. Alzona, B. L. Cohen, H. Rudolph, H. N. Jow, and J. O. Frohliger, "Indoor-outdoor relationships for airborne particulate matter of outdoor origin," Atmospheric Environment (1967), vol. 13, no. 1, pp. 55-60, Jan. 1979, doi: 10.1016/0004-6981(79)90244-0. 
medRxiv preprint doi: https://doi.org/10.1101/2020.05.14.20101311; this version posted May 20, 2020. The copyright holder for this preprint (which was not certified by peer review) is the author/funder, who has granted medRxiv a license to display the preprint in perpetuity. It is made available under a CC-BY-ND 4.0 International license .

M Dillon and

R Sextro

[12] W. W. Nazaroff, "Indoor particle dynamics," Indoor Air, vol. 14, no. s7, pp. 175-183, Aug. 2004, doi: 10.1111/j.1600-0668.2004.00286.x.

[13] US Department of Homeland Security, Federal Emergency Management Agency, Emergency Preparedness and Response Directorate, "Multi-hazard Loss Estimation

1001

1002 Methodology, Earthquake Model, Hazus-MH 4 Technical Manual," US Department of Homeland Security, Federal Emergency Management Agency, Washington DC, Aug. 2009.

1004

[14] A. Persily, A. Musser, and S. J. Emmerich, "Modeled infiltration rate distributions for U.S. housing: Modeled infiltration rate distributions," Indoor Air, vol. 20, no. 6, pp. 473-485, Dec. 2010, doi: 10.1111/j.1600-0668.2010.00669.x.

1006

[15] Z. El Orch, B. Stephens, and M. S. Waring, "Predictions and determinants of size-resolved particle infiltration factors in single-family homes in the U.S.," Building and Environment,

1008 vol. 74, pp. 106-118, Apr. 2014, doi: 10.1016/j.buildenv.2014.01.006.

1009

[16] A. K. Persily, A. Musser, and D. Leber, "A Collection of Homes to Represent the U.S.

1010

1011 Housing Stock," US Department of Commerce, National Institute of Standards and Technology, Washington DC, NISTIR 7330, Aug. 2006.

1012

1013

[17] L. C. Ng, A. Musser, A. K. Persily, and E. S. J. Emmerich, "Airflow and Indoor Air Quality Models of DOE Reference Commercial Buildings," US Department of Commerce, National Institute of Standards and Technology, Washington DC, NIST Technical Note 1734, Feb. 2012.

[18] American Society of Heating, Refrigerating and Air-Conditioning Engineers, "ASHRAE Test Standard 52.2 2012." .

[19] C. Howard-Reed, L. A. Wallace, and S. J. Emmerich, "Effect of ventilation systems and air filters on decay rates of particles produced by indoor sources in an occupied townhouse," Atmospheric Environment, vol. 37, no. 38, pp. 5295-5306, Dec. 2003, doi: 10.1016/j.atmosenv.2003.09.012.

1023

1024

1025

[20] B. C. Singer, W. W. Delp, D. R. Black, and I. S. Walker, "Measured performance of filtration and ventilation systems for fine and ultrafine particles and ozone in an unoccupied modern California house," Indoor Air, vol. 27, no. 4, pp. 780-790, Jul. 2017, doi: 10.1111/ina.12359.

[21] D. L. Maclntosh et al., "The benefits of whole-house in-duct air cleaning in reducing exposures to fine particulate matter of outdoor origin: A modeling analysis," J Expo Sci Environ Epidemiol, vol. 20, no. 2, pp. 213-224, Mar. 2010, doi: 10.1038/jes.2009.16. 
medRxiv preprint doi: https://doi.org/10.1101/2020.05.14.20101311; this version posted May 20, 2020. The copyright holder for this preprint (which was not certified by peer review) is the author/funder, who has granted medRxiv a license to display the preprint in perpetuity. It is made available under a CC-BY-ND 4.0 International license .

M Dillon and

R Sextro

Reducing Exposures to Airborne Particles Through Improved Filtration

1029

1030

1031

1032

1033

1034

1035

1036

1037

1038

1039

1040

1041

1042

1043

1044

1045

1046

1047

1048

1049

1050

1051

1052

1053

1054

1055

1056

1057

1058

1059

1060

1061

[22] W. J. Fisk, D. Faulkner, D. Sullivan, and M. J. Mendell, "Particle Concentrations and Sizes with Normal and High Efficiency Air Filtration in a Sealed Air-Conditioned Office Building," Aerosol Science and Technology, vol. 32, no. 6, pp. 527-544, Jun. 2000, doi: $10.1080 / 027868200303452$.

[23] S. C. van der Zee, M. Strak, M. B. A. Dijkema, B. Brunekreef, and N. A. H. Janssen, "The impact of particle filtration on indoor air quality in a classroom near a highway," Indoor Air, vol. 27, no. 2, pp. 291-302, Mar. 2017, doi: 10.1111/ina.12308.

[24] A. Polidori, P. M. Fine, V. White, and P. S. Kwon, "Pilot study of high-performance air filtration for classroom applications," Indoor Air, vol. 23, no. 3, pp. 185-195, Jun. 2013, doi: 10.1111/ina.12013.

[25] M. Alavy and J. A. Siegel, "IAQ and energy implications of high efficiency filters in residential buildings: A review (RP-1649)," Science and Technology for the Built Environment, vol. 25, no. 3, pp. 261-271, Mar. 2019, doi: 10.1080/23744731.2018.1526012.

[26] California Air Resources Board, "Air Cleaning Devices For the Home: Frequently Asked Questions," California Environmental Protection Agency, Sacramento, CA, Jul. 2014. [Online]. Available: https://ww3.arb.ca.gov/research/indoor/acdsumm.pdf.

[27] US Environmental Protection Agency, "Guide to Air Cleaners in the Home, 2nd Edition," US Environmental Protection Agency, Office of Radiation and Indoor Air, EPA-402-F-08-004, Jul. 2018.

[28] T. Brennan, L. Harriman, B. Stephens, and V. Ilacqua, "Residential Air Cleaners: A Technical Summary, 3rd Edition," US Environmental Protection Agency, Office of Radiation and Indoor Air, EPA 402-F-002, Jul. 2018. [Online]. Available: https://www.epa.gov/sites/production/files/201807/documents/residential_air_cleaners___a_technical_summary_3rd_edition.pdf.

[29] "Residential Energy Consumption Survey (RECS) - 2015 Data - U.S. Energy Information Administration (EIA)." https://www.eia.gov/consumption/residential/data/2015/ (accessed Jan. 19, 2020).

[30] AHAM, "ANSI/AHAM AC-1: Method for Measuring the Performance of Portable Household Electric Room Air Cleaners; Understanding its Scope and the Related AHAM Industry Certification Program," Association of Home Appliance Manufacturers, Washington DC, Aug. 2014. [Online]. Available: https://ahamverifide.org/wpcontent/uploads/2019/07/Scope-of-Air-Cleaner-Certification.pdf. 
medRxiv preprint doi: https://doi.org/10.1101/2020.05.14.20101311; this version posted May 20, 2020. The copyright holder for this preprint (which was not certified by peer review) is the author/funder, who has granted medRxiv a license to display the preprint in perpetuity. It is made available under a CC-BY-ND 4.0 International license .

M Dillon and

R Sextro

Reducing Exposures to Airborne Particles Through Improved Filtration

1062

[31] R. J. Shaughnessy and R. G. Sextro, "What Is an Effective Portable Air Cleaning Device? A Review," Journal of Occupational and Environmental Hygiene, vol. 3, no. 4, pp. 169-181, Apr. 2006, doi: 10.1080/15459620600580129.

1065

1066

1067

[32] D. E. Henderson, J. B. Milford, and S. L. Miller, "Prescribed Burns and Wildfires in Colorado: Impacts of Mitigation Measures on Indoor Air Particulate Matter," Journal of the Air \& Waste Management Association, vol. 55, no. 10, pp. 1516-1526, Oct. 2005, doi:

1068 10.1080/10473289.2005.10464746.

1069

[33] "Air Filtration Standards - AHAM Verifide." https://ahamverifide.org/ahams-air-filtration1070 standards/ (accessed May 09, 2020). 
medRxiv preprint doi: https://doi.org/10.1101/2020.05.14.20101311; this version posted May 20, 2020. The copyright holder for this preprint (which was not certified by peer review) is the author/funder, who has granted medRxiv a license to display the preprint in perpetuity.

It is made available under a CC-BY-ND 4.0 International license.

M Dillon and

Reducing Exposures to Airborne

R Sextro

Particles Through Improved Filtration

1072 Supplemental Material A: Detailed Results

1073

1074

1075

1076 The companion spreadsheet contains our modeling results for four filtration scenarios (baseline

1077 and three improvement scenarios) for each of the 32 building use types. The outputs for each

1078 filter and building combination include five aerosol sizes $(0.1,0.3,1,3,10 \mu \mathrm{m}$ diameter) and

1079 four airborne loss rates $\left(0,0.1,1,10 \mathrm{hr}^{-1}\right)$. 
medRxiv preprint doi: https://doi.org/10.1101/2020.05.14.20101311; this version posted May 20, 2020. The copyright holder for this preprint (which was not certified by peer review) is the author/funder, who has granted medRxiv a license to display the preprint in perpetuity.

It is made available under a CC-BY-ND 4.0 International license .

M Dillon and

R Sextro
Reducing Exposures to Airborne

Particles Through Improved Filtration

1080 Supplemental Material B: Results Summary

1081 Table B1. Summary of US Building Transmission Factors - the ratio of the indoor exposures to 1082 the corresponding outdoor exposure - for selected building types, two aerosol sizes, and the $1083 \quad \mathbf{O ~}^{-1}$ airborne loss rate. (dimensionless)

\begin{tabular}{|c|c|c|c|c|c|c|c|}
\hline \multirow{2}{*}{$\begin{array}{c}\text { Select } \\
\text { Buildings } \\
\text { (Use Types) }\end{array}$} & \multirow[b]{2}{*}{$\begin{array}{l}\text { Baseline } \\
\text { Scenario }\end{array}$} & \multicolumn{2}{|c|}{ Absolute Values } & \multirow[b]{2}{*}{$\begin{array}{c}\text { Min } \\
\text { MERV } 14 \\
\text { Scenario }\end{array}$} & \multicolumn{3}{|c|}{$\begin{array}{c}\text { Relative Improvement from } \\
\text { Baseline Scenario }\end{array}$} \\
\hline & & $\begin{array}{c}\text { Min } \\
\text { MERV } 7 \\
\text { Scenario }\end{array}$ & $\begin{array}{c}\text { Min } \\
\text { MERV } 11 \\
\text { Scenario }\end{array}$ & & $\begin{array}{c}\text { Min } \\
\text { MERV } 7 \\
\text { Scenario }\end{array}$ & $\begin{array}{c}\text { Min } \\
\text { MERV } 11 \\
\text { Scenario }\end{array}$ & $\begin{array}{c}\text { Min } \\
\text { MERV } 14 \\
\text { Scenario }\end{array}$ \\
\hline \multicolumn{8}{|c|}{$1 \mu \mathrm{m}$ aerodynamic diameter } \\
\hline $\begin{array}{l}\text { Single Family } \\
\text { Homes (RES1) }\end{array}$ & 0.35 & 0.21 & 0.21 & 0.19 & 1.6 & 1.6 & 1.8 \\
\hline $\begin{array}{c}\text { Small Apt } \\
\text { (RES3B, RES3C) }\end{array}$ & 0.18 & 0.055 & 0.054 & 0.034 & 3.2 & 3.2 & 5.1 \\
\hline $\begin{array}{c}\text { Large Apt } \\
\text { (RES3E, RES3F) }\end{array}$ & 0.17 & 0.057 & 0.056 & 0.024 & 3.0 & 3.1 & 7.2 \\
\hline $\begin{array}{l}\text { Retail Stores } \\
\quad(\mathrm{COM} 1)\end{array}$ & 0.29 & 0.16 & 0.16 & 0.060 & 1.8 & 1.8 & 4.8 \\
\hline $\begin{array}{l}\text { Offices (COM4, } \\
\text { COM5, GOV1) }\end{array}$ & 0.25 & 0.18 & 0.18 & 0.056 & 1.4 & 1.4 & 4.4 \\
\hline Schools (EDU1) & 0.34 & 0.20 & 0.20 & 0.078 & 1.7 & 1.7 & 4.4 \\
\hline \multicolumn{8}{|c|}{$3 \mu \mathrm{m}$ aerodynamic diameter } \\
\hline $\begin{array}{l}\text { Single Family } \\
\text { Homes (RES1) }\end{array}$ & 0.16 & 0.10 & 0.10 & 0.10 & 1.6 & 1.6 & 1.6 \\
\hline $\begin{array}{c}\text { Small Apt } \\
\text { (RES3B, RES3C) }\end{array}$ & 0.066 & 0.025 & 0.025 & 0.022 & 2.6 & 2.6 & 3.0 \\
\hline $\begin{array}{c}\text { Large Apt } \\
\text { (RES3E, RES3F) }\end{array}$ & 0.052 & 0.020 & 0.020 & 0.015 & 2.5 & 2.6 & 3.4 \\
\hline $\begin{array}{l}\text { Retail Stores } \\
\qquad(\mathrm{COM} 1)\end{array}$ & 0.11 & 0.055 & 0.055 & 0.036 & 2.0 & 2.0 & 3.1 \\
\hline $\begin{array}{l}\text { Offices (COM4, } \\
\text { cOM5, GOV1) }\end{array}$ & 0.10 & 0.059 & 0.057 & 0.032 & 1.6 & 1.7 & 3.0 \\
\hline Schools (EDU1) & 0.14 & 0.073 & 0.071 & 0.048 & 1.9 & 2.0 & 2.9 \\
\hline
\end{tabular}


medRxiv preprint doi: https://doi.org/10.1101/2020.05.14.20101311; this version posted May 20, 2020. The copyright holder for this preprint (which was not certified by peer review) is the author/funder, who has granted medRxiv a license to display the preprint in perpetuity.

It is made available under a CC-BY-ND 4.0 International license .

M Dillon and

R Sextro
Reducing Exposures to Airborne

Particles Through Improved Filtration
1084

1085

1086

Table B2. Summary of US Indoor Normalized Time and Space Integrated Air Concentrations (Indoor Normalized TSIAC) - indoor exposures to indoor-origin airborne particles - for selected building types, two aerosol sizes, and the $0 \mathrm{~h}^{-1}$ airborne loss rate. $\left(\mathrm{s} \mathrm{m}^{-1}\right)$

\begin{tabular}{|c|c|c|c|c|c|c|c|}
\hline \multirow{2}{*}{$\begin{array}{c}\text { Select } \\
\text { Buildings } \\
\text { (Use Types) }\end{array}$} & \multirow[b]{2}{*}{$\begin{array}{l}\text { Baseline } \\
\text { Scenario }\end{array}$} & \multicolumn{3}{|c|}{ Absolute Values } & \multicolumn{3}{|c|}{$\begin{array}{c}\text { Relative Improvement from } \\
\text { Baseline Scenario }\end{array}$} \\
\hline & & $\begin{array}{c}\text { Min } \\
\text { MERV } 7 \\
\text { Scenario }\end{array}$ & $\begin{array}{c}\text { Min } \\
\text { MERV } 11 \\
\text { Scenario }\end{array}$ & $\begin{array}{c}\text { Min } \\
\text { MERV } 14 \\
\text { Scenario }\end{array}$ & $\begin{array}{c}\text { Min } \\
\text { MERV } 7 \\
\text { Scenario }\end{array}$ & $\begin{array}{c}\text { Min } \\
\text { MERV } 11 \\
\text { Scenario }\end{array}$ & $\begin{array}{c}\text { Min } \\
\text { MERV } 14 \\
\text { Scenario }\end{array}$ \\
\hline \multicolumn{8}{|c|}{$1 \mu \mathrm{m}$ aerodynamic diameter } \\
\hline $\begin{array}{l}\text { Single Family } \\
\text { Homes (RES1) }\end{array}$ & 18 & 11 & 10 & 9.8 & 1.7 & 1.7 & 1.8 \\
\hline $\begin{array}{c}\text { Small Apt } \\
\text { (RES3B, RES3C) }\end{array}$ & 15 & 4.5 & 4.5 & 3.0 & 3.3 & 3.4 & 5.0 \\
\hline $\begin{array}{c}\text { Large Apt } \\
\text { (RES3E, RES3F) }\end{array}$ & 9.6 & 4.0 & 4.0 & 2.6 & 2.4 & 2.4 & 3.7 \\
\hline $\begin{array}{l}\text { Retail Stores } \\
\text { (COM1) }\end{array}$ & 6.3 & 4.8 & 4.7 & 3.7 & 1.3 & 1.3 & 1.7 \\
\hline $\begin{array}{l}\text { Offices (COM4, } \\
\text { COM5, GOV1) }\end{array}$ & 3.3 & 3.0 & 2.9 & 2.4 & 1.1 & 1.1 & 1.4 \\
\hline Schools (EDU1) & 5.0 & 4.1 & 4.0 & 3.2 & 1.2 & 1.2 & 1.5 \\
\hline \multicolumn{8}{|c|}{$3 \mu \mathrm{m}$ aerodynamic diameter } \\
\hline $\begin{array}{l}\text { Single Family } \\
\text { Homes (RES1) }\end{array}$ & 10 & 6.7 & 6.5 & 6.4 & 1.5 & 1.6 & 1.6 \\
\hline $\begin{array}{c}\text { Small Apt } \\
\text { (RES3B, RES3C) }\end{array}$ & 7.2 & 2.8 & 2.8 & 2.6 & 2.6 & 2.6 & 2.8 \\
\hline $\begin{array}{c}\text { Large Apt } \\
\text { (RES3E, RES3F) }\end{array}$ & 4.4 & 2.6 & 2.5 & 2.3 & 1.7 & 1.7 & 1.9 \\
\hline $\begin{array}{l}\text { Retail Stores } \\
\text { (COM1) }\end{array}$ & 3.9 & 3.4 & 3.4 & 3.2 & 1.2 & 1.2 & 1.2 \\
\hline $\begin{array}{l}\text { Offices (COM4, } \\
\text { COM5, GOV1) }\end{array}$ & 2.4 & 2.3 & 2.2 & 2.1 & 1.1 & 1.1 & 1.1 \\
\hline Schools (EDU1) & 3.4 & 3.0 & 3.0 & 2.8 & 1.1 & 1.1 & 1.2 \\
\hline
\end{tabular}


medRxiv preprint doi: https://doi.org/10.1101/2020.05.14.20101311; this version posted May 20, 2020. The copyright holder for this preprint (which was not certified by peer review) is the author/funder, who has granted medRxiv a license to display the preprint in perpetuity.

It is made available under a CC-BY-ND 4.0 International license .

M Dillon and

R Sextro
Reducing Exposures to Airborne

Particles Through Improved Filtration
1088

1089

1090

Table B3. Summary of US Building Exit Fractions - the fraction of indoor airborne particles that are released to the outdoor atmosphere - for selected building types, two aerosol sizes, and the $\mathrm{O} \mathrm{h}^{-1}$ airborne loss rate. (dimensionless)

\begin{tabular}{|c|c|c|c|c|c|c|c|}
\hline \multirow{2}{*}{$\begin{array}{c}\text { Select } \\
\text { Buildings } \\
\text { (Use Types) }\end{array}$} & \multirow[b]{2}{*}{$\begin{array}{l}\text { Baseline } \\
\text { Scenario }\end{array}$} & \multicolumn{3}{|c|}{ Absolute Values } & \multicolumn{3}{|c|}{$\begin{array}{c}\text { Relative Improvement from } \\
\text { Baseline Scenario }\end{array}$} \\
\hline & & $\begin{array}{c}\text { Min } \\
\text { MERV } 7 \\
\text { Scenario }\end{array}$ & $\begin{array}{c}\text { Min } \\
\text { MERV } 11 \\
\text { Scenario }\end{array}$ & $\begin{array}{c}\text { Min } \\
\text { MERV } 14 \\
\text { Scenario }\end{array}$ & $\begin{array}{c}\text { Min } \\
\text { MERV } 7 \\
\text { Scenario }\end{array}$ & $\begin{array}{c}\text { Min } \\
\text { MERV } 11 \\
\text { Scenario }\end{array}$ & $\begin{array}{c}\text { Min } \\
\text { MERV } 14 \\
\text { Scenario }\end{array}$ \\
\hline \multicolumn{8}{|c|}{$1 \mu \mathrm{m}$ aerodynamic diameter } \\
\hline $\begin{array}{l}\text { Single Family } \\
\text { Homes (RES1) }\end{array}$ & 0.34 & 0.21 & 0.21 & 0.19 & 1.6 & 1.6 & 1.8 \\
\hline $\begin{array}{c}\text { Small Apt } \\
\text { (RES3B, RES3C) }\end{array}$ & 0.18 & 0.060 & 0.059 & 0.040 & 3.0 & 3.0 & 4.5 \\
\hline $\begin{array}{c}\text { Large Apt } \\
\text { (RES3E, RES3F) }\end{array}$ & 0.19 & 0.087 & 0.086 & 0.057 & 2.2 & 2.2 & 3.4 \\
\hline $\begin{array}{l}\text { Retail Stores } \\
\text { (COM1) }\end{array}$ & 0.40 & 0.32 & 0.31 & 0.25 & 1.3 & 1.3 & 1.6 \\
\hline $\begin{array}{l}\text { Offices (COM4, } \\
\text { COM5, GOV1) }\end{array}$ & 0.47 & 0.43 & 0.43 & 0.37 & 1.1 & 1.1 & 1.3 \\
\hline Schools (EDU1) & 0.49 & 0.40 & 0.39 & 0.32 & 1.2 & 1.2 & 1.5 \\
\hline \multicolumn{8}{|c|}{$3 \mu \mathrm{m}$ aerodynamic diameter } \\
\hline $\begin{array}{l}\text { Single Family } \\
\text { Homes (RES1) }\end{array}$ & 0.17 & 0.10 & 0.10 & 0.10 & 1.6 & 1.6 & 1.6 \\
\hline $\begin{array}{c}\text { Small Apt } \\
\text { (RES3B, RES3C) }\end{array}$ & 0.070 & 0.030 & 0.030 & 0.028 & 2.3 & 2.4 & 2.5 \\
\hline $\begin{array}{c}\text { Large Apt } \\
\text { (RES3E, RES3F) }\end{array}$ & 0.079 & 0.051 & 0.050 & 0.046 & 1.6 & 1.6 & 1.7 \\
\hline $\begin{array}{l}\text { Retail Stores } \\
\qquad(\mathrm{COM} 1)\end{array}$ & 0.25 & 0.22 & 0.22 & 0.21 & 1.1 & 1.1 & 1.2 \\
\hline $\begin{array}{l}\text { Offices (COM4, } \\
\text { COM5, GOV1) }\end{array}$ & 0.36 & 0.34 & 0.34 & 0.33 & 1.1 & 1.0 & 1.1 \\
\hline Schools (EDU1) & 0.32 & 0.28 & 0.28 & 0.27 & 1.1 & 1.1 & 1.2 \\
\hline
\end{tabular}


medRxiv preprint doi: https://doi.org/10.1101/2020.05.14.20101311; this version posted May 20, 2020. The copyright holder for this preprint (which was not certified by peer review) is the author/funder, who has granted medRxiv a license to display the preprint in perpetuity.

It is made available under a CC-BY-ND 4.0 International license .

M Dillon and

Reducing Exposures to Airborne

R Sextro

Particles Through Improved Filtration

1092 Table B4. Summary of US Indoor Downwind Exposure Improvements for selected building

1093 types, two aerosol sizes, and the $\mathbf{0} \mathbf{h}^{-1}$ airborne loss rate. (dimensionless)

\begin{tabular}{|c|c|c|c|}
\hline \multirow{2}{*}{$\begin{array}{c}\text { Select Buildings } \\
\text { (Use Types) }\end{array}$} & $\begin{array}{c}\text { Min MERV 7 } \\
\text { Scenario }\end{array}$ & $\begin{array}{c}\text { Min MERV 11 } \\
\text { Scenario }\end{array}$ & $\begin{array}{c}\text { Min MERV 14 } \\
\text { Scenario }\end{array}$ \\
\hline \multicolumn{3}{|c|}{$\mathbf{1 \mu \mathrm { m } \text { aerodynamic diameter }}$} \\
\hline Single Family Homes (RES1) & 2.6 & 2.6 & 3.2 \\
Small Apt (RES3B, RES3C) & 9.6 & 9.8 & 23 \\
\hline Large Apt (RES3E, RES3F) & 6.6 & 6.8 & 24 \\
\hline
\end{tabular}

$3 \mu \mathrm{m}$ aerodynamic diameter

\begin{tabular}{|c|c|c|c|}
\hline Single Family Homes (RES1) & 2.5 & 2.6 & 2.6 \\
Small Apt (RES3B, RES3C) & 6.2 & 6.2 & 7.5 \\
Large Apt (RES3E, RES3F) & 4.0 & 4.2 & 5.8 \\
\hline
\end{tabular}

1094 
medRxiv preprint doi: https://doi.org/10.1101/2020.05.14.20101311; this version posted May 20, 2020. The copyright holder for this preprint (which was not certified by peer review) is the author/funder, who has granted medRxiv a license to display the preprint in perpetuity. It is made available under a CC-BY-ND 4.0 International license .

M Dillon and

R Sextro

Reducing Exposures to Airborne Particles Through Improved Filtration

1095 Supplemental Material C: Additional Building Metric Figures

1096

1097 Figure C1 shows the Building Transmission Factors for the improved filtration scenarios. The 1098 indoor/outdoor exposure ratios are all smaller for the improved filtration scenarios than for the 1099 baseline case for the six building types, Figure 1, by the factors illustrated in Figure 2.

1101 Figure C2 shows the Indoor Normalized TSIAC for the improved filtration scenarios. The indoor 1102 exposure ratios are all smaller for the improved filtration scenarios than for the baseline case 1103 for the six building types, Figure 3, by the factors illustrated in Figure 4. Note the change in 1104 vertical scale from Figure 3.

1106 Figure C3 shows the Building Exit Fraction for the improved filtration scenarios. The Building 1107 Exit Fractions are all smaller for the improved filtration scenarios than for the baseline case for 1108 the six building types, Figure 5, by the factors illustrated in Figure 6. 
medRxiv preprint doi: https://doi.org/10.1101/2020.05.14.20101311; this version posted May 20, 2020. The copyright holder for this preprint (which was not certified by peer review) is the author/funder, who has granted medRxiv a license to display the preprint in perpetuity.

It is made available under a CC-BY-ND 4.0 International license .

M Dillon and

R Sextro
Reducing Exposures to Airborne Particles Through Improved Filtration
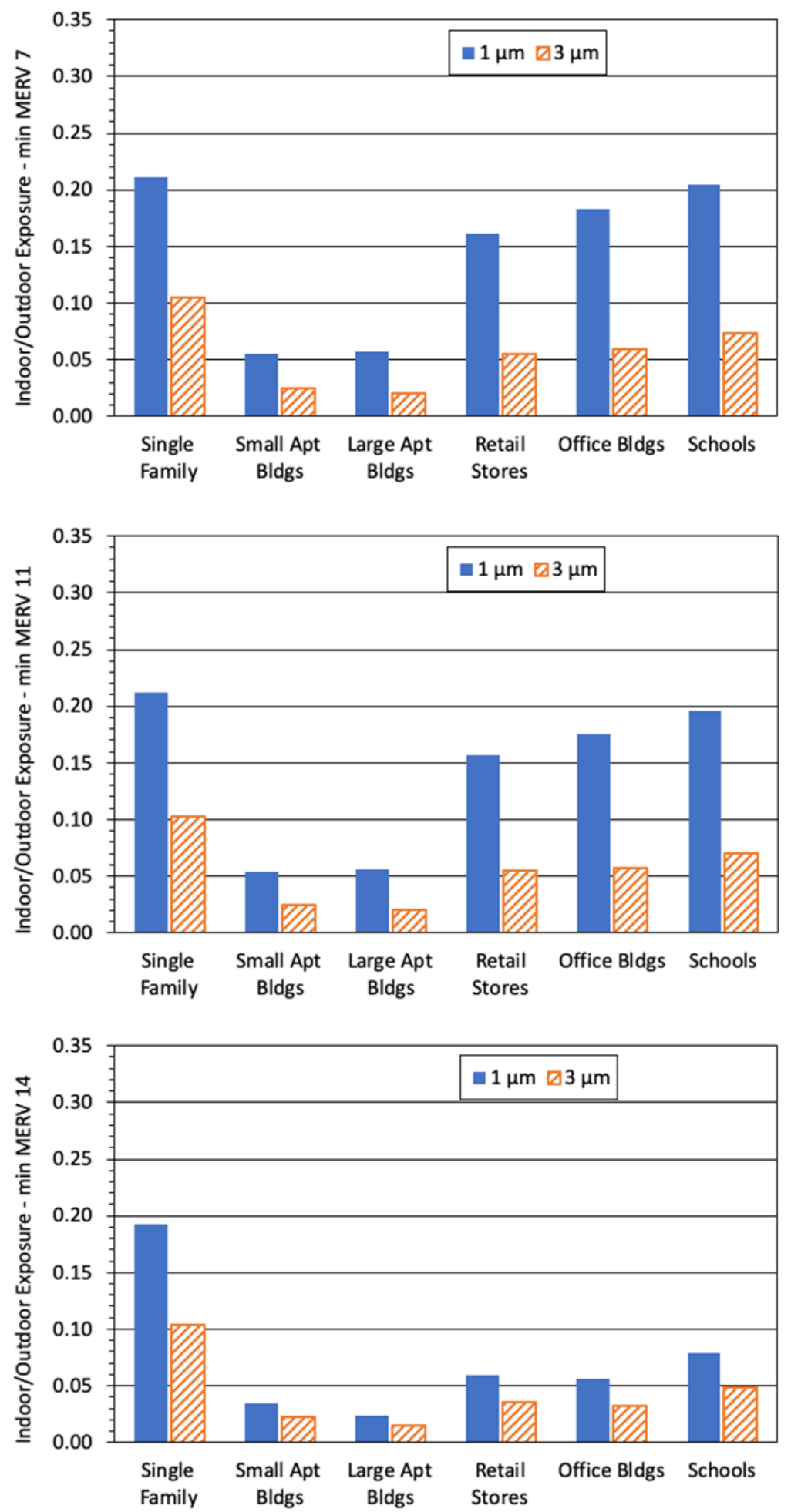

Figure C1. Improved filtration scenario results for the US Building Transmission Factor (dimensionless) - the ratio of the indoor exposures to the corresponding outdoor exposure 1113 for selected building types; two aerosol sizes: $1 \mu \mathrm{m}$ (solid bar) and $3 \mu \mathrm{m}$ diameter (diagonal 1114 striped bar); and a $\mathrm{O} \mathrm{h}^{-1}$ airborne loss rate. Higher Building Transmission Factor values 1115 correspond to greater exposures. 
medRxiv preprint doi: https://doi.org/10.1101/2020.05.14.20101311; this version posted May 20, 2020. The copyright holder for this preprint (which was not certified by peer review) is the author/funder, who has granted medRxiv a license to display the preprint in perpetuity.

It is made available under a CC-BY-ND 4.0 International license .

M Dillon and

R Sextro
Reducing Exposures to Airborne

Particles Through Improved Filtration
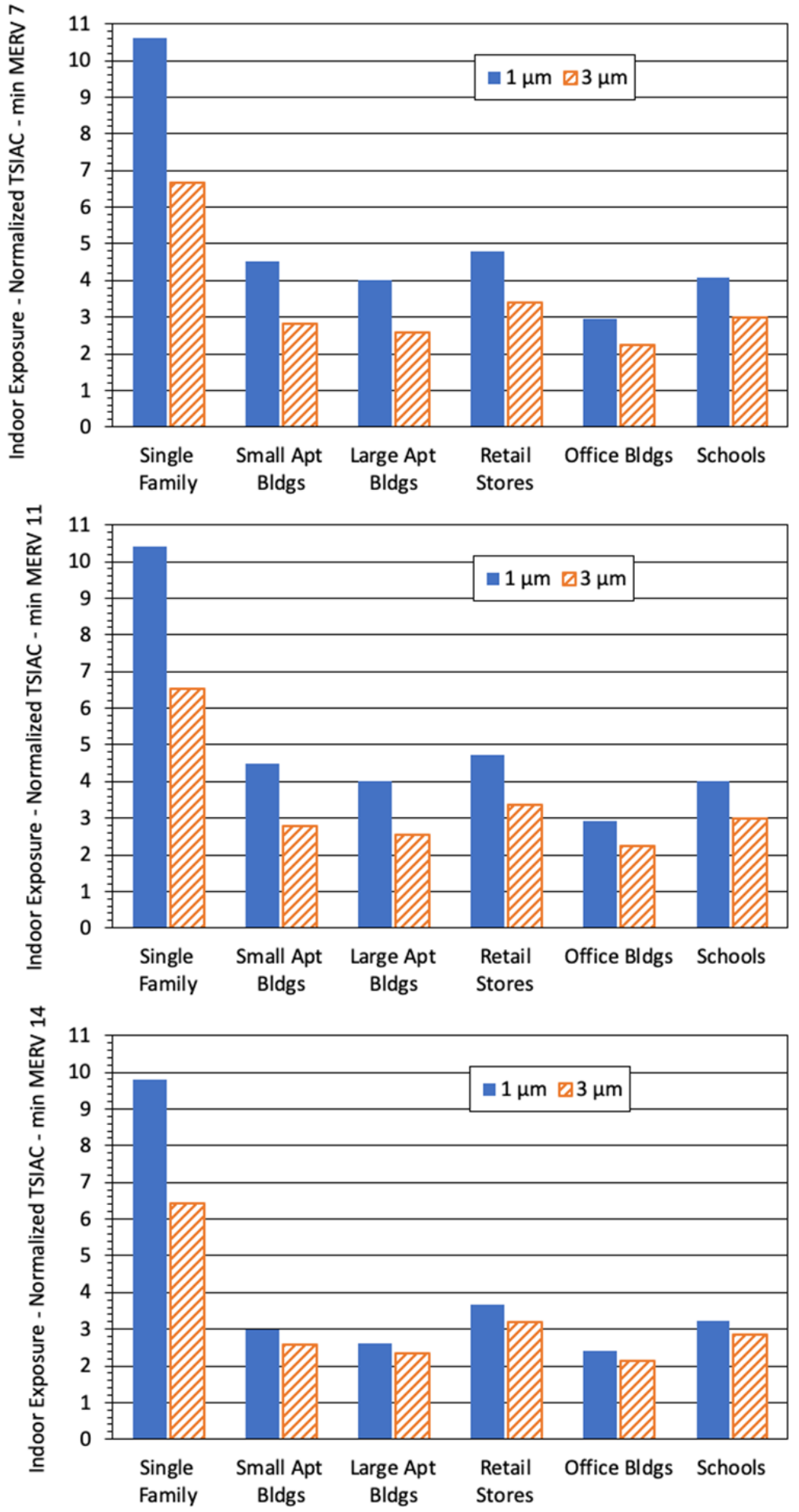

Figure C2. Improved filtration scenario results for the US Indoor Normalized Time and Space Integrated Air Concentration (Indoor Normalized TSIAC in s $\mathrm{m}^{-1}$ ) - indoor exposures to indoororigin airborne particles - for selected building types; two aerosol sizes: $1 \mu \mathrm{m}$ (solid bar) and 3 $\mu \mathrm{m}$ diameter (diagonal striped bar); and a $0 \mathrm{~h}^{-1}$ airborne loss rate. Higher Indoor Normalized TSIAC values correspond to greater exposures. Note the change in vertical scale from Figure 3. 
medRxiv preprint doi: https://doi.org/10.1101/2020.05.14.20101311; this version posted May 20, 2020. The copyright holder for this preprint (which was not certified by peer review) is the author/funder, who has granted medRxiv a license to display the preprint in perpetuity.

It is made available under a CC-BY-ND 4.0 International license .

M Dillon and

R Sextro
Reducing Exposures to Airborne Particles Through Improved Filtration
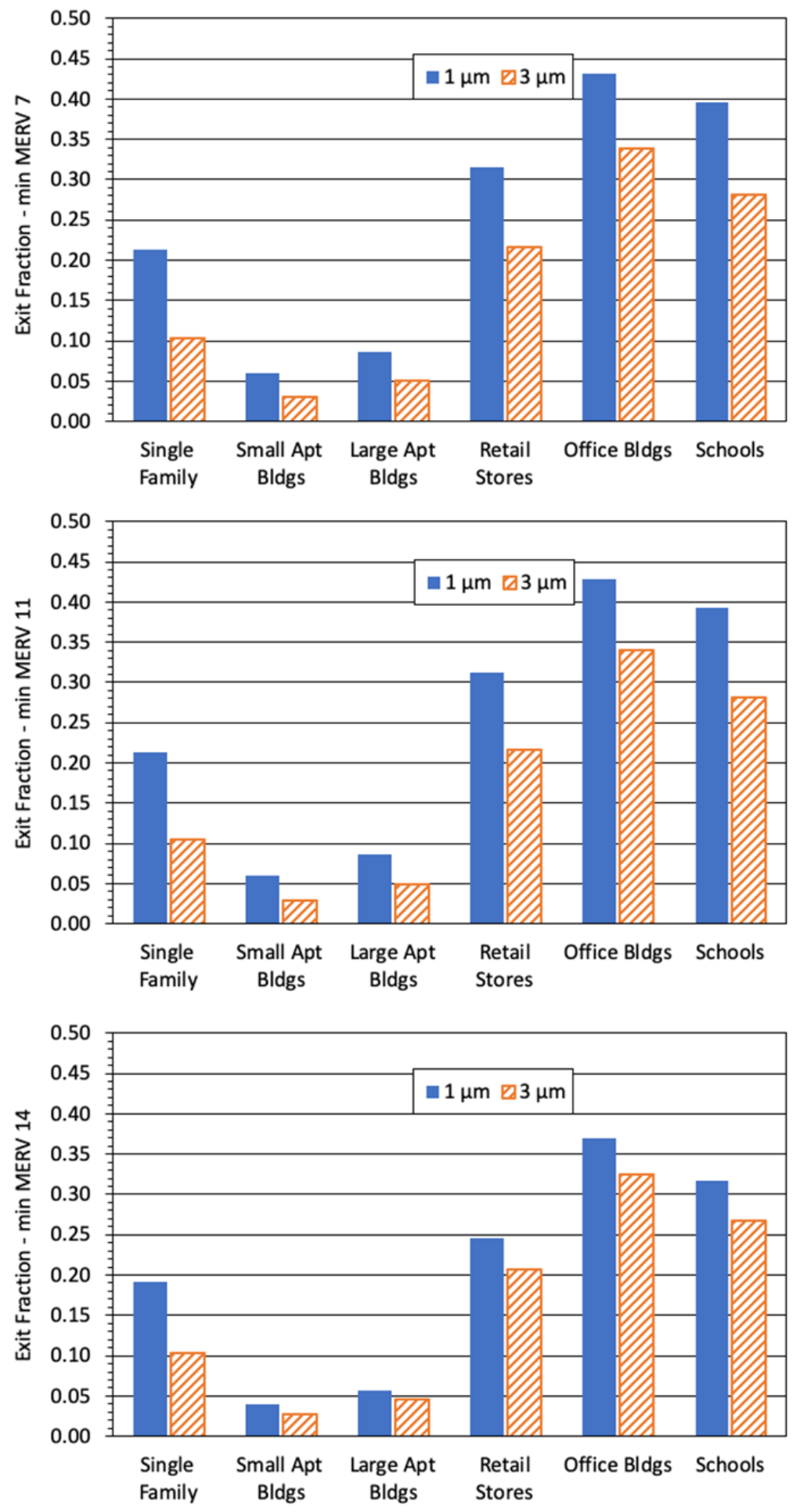

Figure C3. Improved filtration scenario results for the US Building Exit Fractions (dimensionless) - the fraction of indoor airborne particles that are released to the outdoor atmosphere - for selected building types; two aerosol sizes: $1 \mu \mathrm{m}$ (solid bar) and $3 \mu \mathrm{m}$ diameter (diagonal striped bar); and a $0 \mathrm{~h}^{-1}$ airborne loss rate. Higher Exit Fraction values correspond to more particles released to the outdoor atmosphere. 
medRxiv preprint doi: https://doi.org/10.1101/2020.05.14.20101311; this version posted May 20, 2020. The copyright holder for this preprint (which was not certified by peer review) is the author/funder, who has granted medRxiv a license to display the preprint in perpetuity. It is made available under a CC-BY-ND 4.0 International license .

M Dillon and

R Sextro

Reducing Exposures to Airborne Particles Through Improved Filtration

\section{Supplemental Material D: Improvement Sensitivity to Particle Size and}

\section{Airborne Loss Rate}

1131 Figures D1 to D3 illustrates how the improvements to (reduction in) indoor airborne particle

1132 exposure varies with airborne loss rate and particle size using the Building Transmission Factor

1133 metric, the Minimum MERV 14 scenario, and selected building types. Broadly, the improvement

1134 decreases with increasing "generic" first-order airborne loss rate, $\lambda_{\text {decay }}$ and particle size. The

1135 small and large apartment building improvements are sensitive to airborne loss rate and

1136 particle size. The single family home, retail store, office building and school improvements are

1137 notably less sensitive.

1138 
medRxiv preprint doi: https://doi.org/10.1101/2020.05.14.20101311; this version posted May 20, 2020. The copyright holder for this preprint (which was not certified by peer review) is the author/funder, who has granted medRxiv a license to display the preprint in perpetuity.

It is made available under a CC-BY-ND 4.0 International license .

M Dillon and

Reducing Exposures to Airborne

R Sextro

Particles Through Improved Filtration

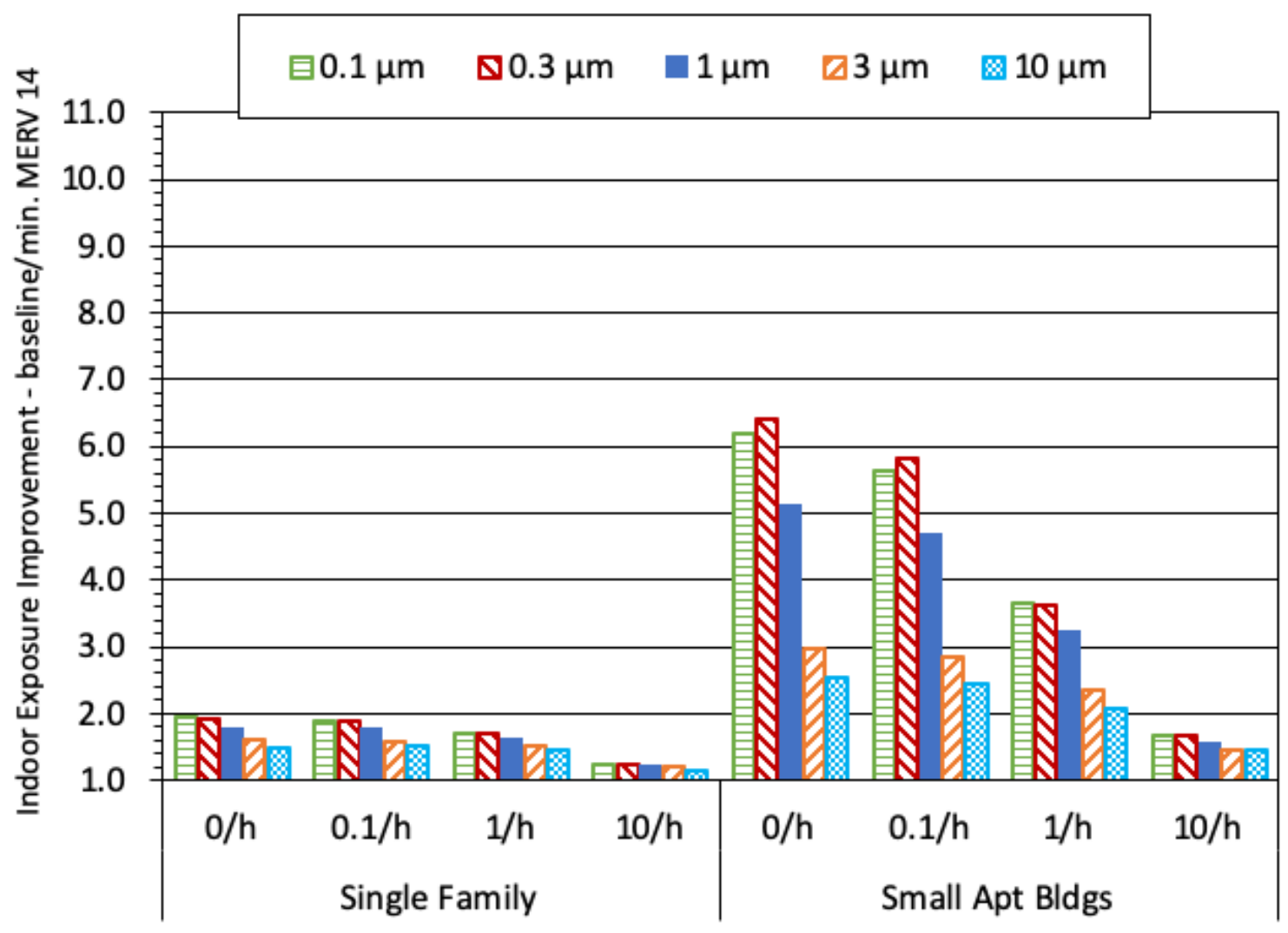

Figure D1. Improvement in the US Building Transmission Factor for two residential building types; five aerosol sizes: $0.1 \mu \mathrm{m}$ (horizontal striped bar), $0.3 \mu \mathrm{m}$ (downward diagonal striped

1142 bar, $1 \mu \mathrm{m}$ (solid bar), $3 \mu \mathrm{m}$ diameter (upward diagonal striped bar), and $10 \mu \mathrm{m}$ diameter

1143 particles (cross-hatched bar); and four airborne loss rates: 0, 0.1, 1, and $10 \mathrm{~h}^{-1}$. The vertical axis

1144 is the ratio of the Building Transmission Factors for the baseline to the Minimum MERV 14

1145 filtration scenario (a value of 1 indicates no improvement, larger numbers indicate greater 1146 improvement). 
medRxiv preprint doi: https://doi.org/10.1101/2020.05.14.20101311; this version posted May 20, 2020. The copyright holder for this preprint (which was not certified by peer review) is the author/funder, who has granted medRxiv a license to display the preprint in perpetuity.

It is made available under a CC-BY-ND 4.0 International license .

M Dillon and

R Sextro
Reducing Exposures to Airborne

Particles Through Improved Filtration

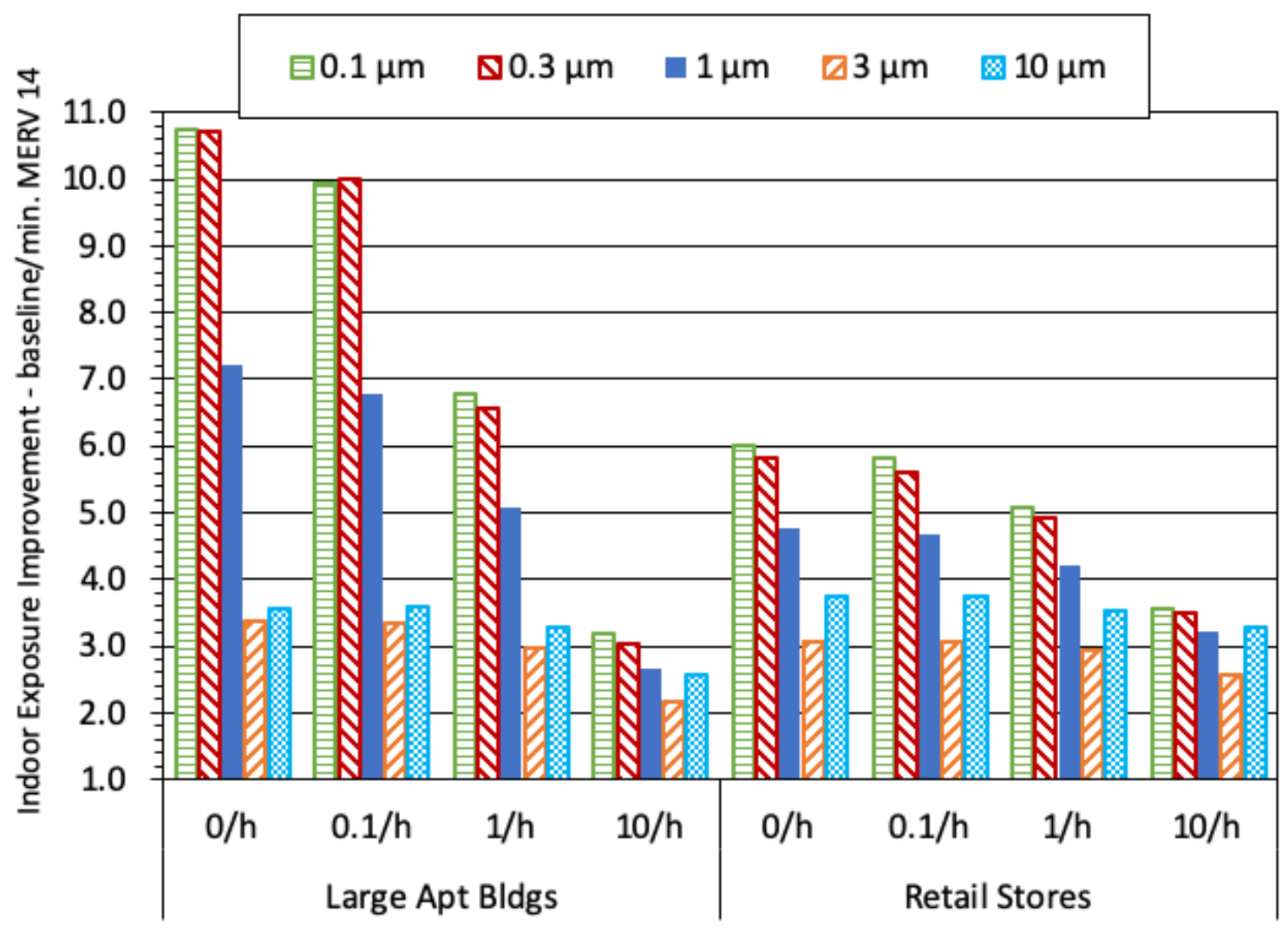

1149 Figure D2. Improvement in the US Building Transmission Factor for large apartments and retail 1150 stores; five aerosol sizes: $0.1 \mu \mathrm{m}$ (horizontal striped bar), $0.3 \mu \mathrm{m}$ (downward diagonal striped 1151 bar, $1 \mu \mathrm{m}$ (solid bar), $3 \mu \mathrm{m}$ diameter (upward diagonal striped bar), and $10 \mu \mathrm{m}$ diameter 1152 particles (cross-hatched bar); and four airborne loss rates: 0, 0.1, 1, and $10 \mathrm{~h}^{-1}$. The vertical axis 1153 is the ratio of the Building Transmission Factors for the baseline to the Minimum MERV 14 1154 filtration scenario (a value of 1 indicates no improvement, larger numbers indicate greater 1155 improvement). 
medRxiv preprint doi: https://doi.org/10.1101/2020.05.14.20101311; this version posted May 20, 2020. The copyright holder for this preprint (which was not certified by peer review) is the author/funder, who has granted medRxiv a license to display the preprint in perpetuity.

It is made available under a CC-BY-ND 4.0 International license .

M Dillon and

R Sextro
Reducing Exposures to Airborne Particles Through Improved Filtration

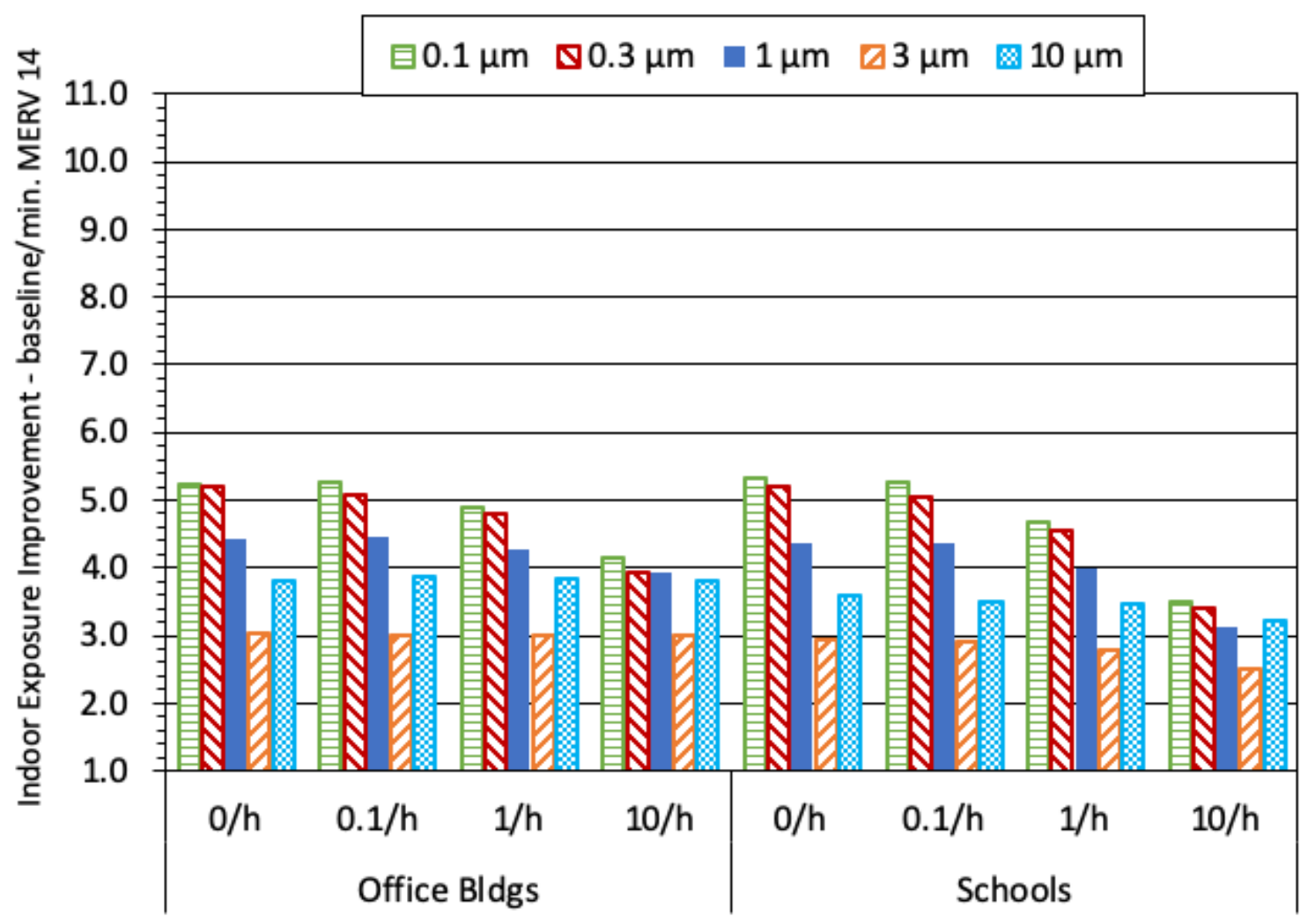

1158 Figure D3. Improvement in the US Building Transmission Factor for office buildings and schools; 1159 five aerosol sizes: $0.1 \mu \mathrm{m}$ (horizontal striped bar); $0.3 \mu \mathrm{m}$ (downward diagonal striped bar, $1 \mu \mathrm{m}$ 1160 (solid bar), $3 \mu \mathrm{m}$ diameter (upward diagonal striped bar), and $10 \mu \mathrm{m}$ diameter particles (cross1161 hatched bar); and four airborne loss rates: $0,0.1,1$, and $10 \mathrm{~h}^{-1}$. The vertical axis is the ratio of 1162 the Building Transmission Factors for the baseline to the Minimum MERV 14 scenario (a value 1163 of 1 indicates no improvement, larger numbers indicate greater improvement). 